\title{
Facies, composition and provenance of the Agnone Flysch in the context of the early Messinian evolution of the southern Apennine foredeep (Molise, Italy)
}

\author{
Salvatore Milli $(1,2)$, Salvatore Critelli (3), Emanuele Amicone (4), Gloria Campilongo (3), \\ Francesco Muto (3), Vincenzo Tripodi (3), Daniel Tentori (2) \& Francesco Perri (3)
}

\section{ABSTRACT}

Clastic wedges deposited in deep-marine turbidite systems along the circum-Mediterranean region represent key tectonic elements that record the structural growing of the Apennine orogenic belt over the Adria margin. One of these clastic wedges is represented by the Agnone Flysch turbidite succession deposited in the Lagonegro-Molise foredeep basin in the early Messinian, for which the depositional facies and the related processes, as well as the sandstone and mudstone composition are poorly known. A combined sedimentology and sedimentary petrology study has been conducted on this turbidite succession that provides new insight to define the basin architecture and the provenance of the Agnone Flysch during late Miocene. Facies analysis suggests that this turbidite succession is constituted by depositional lobes that were emplaced in a sector of the basin showing a variable morphological confinement with frontal and lateral slope on which turbidite deposits onlapped. Consequently, this topographic context controlled the lateral and vertical distribution of turbidite facies, which record the effects of erosive processes, as well as impact, rebound and reflection processes, in turn related to the flow deceleration induced by structurally-controlled basin confinement. Detailed sandstones compositional analysis indicates a complex unroofing history that reflects structural changes in the source rock units and depositional basin physiography. By combining the sandstone composition with information deduced from the X-ray diffraction (XRD) patterns after thermo-chemical treatments (heating and ethylene glycol treatments), it was possible to explain and predict the sedimentary evolution and geological processes affecting fine grained sediments and, thus, the relationship developed between source area and sedimentary basin. In particular, clay minerals data show that Agnone Flysch experienced an early diagenetic condition as showed by the occurrence of the I/S R0 and I/S R1 on the XRD pattern of the glycolated specimens. The sandstone composition (mainly quartzofeldspathic) shows an increase in the metamorphic rock fragments and a decrease of sedimentary lithics up-section. This compositional trend records, together with the paleocurrents data, a derivation of this material from a mountain range located in the Tyrrhenian sector and from the Calabrian arc terranes.

KEY wORDs: Agnone Flysch, turbidite facies, composition, provenance, sandstone, late Miocene, southern Apennines.

(1) Dipartimento di Scienze della Terra, SAPIENZA Università di Roma, Piazzale Aldo Moro 5, 00185, Roma, Italy. E-mail: salvatore. milli@uniroma1.it

(2) Istituto di Geologia Ambientale e Geoingegneria (IGAG), Consiglio Nazionale delle Ricerche, Via Salaria km 29,300 - 00015 Montelibretti (RM), Italy

(3) Dipartimento di Biologia, Ecologia e Scienze della Terra, Università della Calabria, Ponte Pietro Bucci, Cubo 15B, 87036 Arcavacata di Rende, CS, Italy

(4) Freelance geologist

Corresponding author e-mail: salvatore.milli@uniroma1.it

\section{INTRODUCTION}

The southern Apennine Chain is largely studied to investigate the geodynamic evolution of the Cenozoic foreland region. However, as evidenced by several studies conducted in years (D'Argenio et alii, 1973; Patacca et alii, 1991; Mattei et alii, 2007; Patacca \& Scandone, 2007; Bonardi et alii, 2009; Scrocca, 2010; Vitale \& Ciarcia, 2013), the history of this chain is very complex and characterized by an assemblage of tectonic units whose organization and superimposition are not always clear. This is reflected in the regional geological models proposed by the Authors, for which the different interpretations often derive by an unclear knowledge of the physical stratigraphy and facies analysis of the deposits, especially for the turbidite deposits. For the latter, in fact, are better known the compositional trends that successfully were used to detect the geodynamic evolution and changes in provenance related to the growing of the Apennine orogenic belt (CRITELli, 1991, 2018; CRITELli \& INGERsoll, 1994; CRITELli \& Le Pera, 1994, 1995a, 1998; Critelli et alii, 2007, 2011, 2013, 2017; STALDER et alii, 2018). A noteworthy database of sandstone samples were reported in literature (e.g. ZuFFA, 1980; Critelli \& Le Pera, 1990, 1994, 1995a, 1995b, 1998; Critelli, 1993, 1999, 2018; Fornelli \& PiCARreta, 1997; CRITELli et alii, 1990a, b, 1994, 2007, 2008, 2011, 2013, 2017; Barone et alii, 2006, 2008; Perri et alii, 2012a, b; CARACCIOLO et alii, 2013; ZECCHIN et alii, 2013a, b, 2020; MATANo et alii, 2014, 2020; AMENDOLA et alii, 2016) and through these data, paleotectonic and paleogeographic interpretations were carried out. Moreover other important information, that represent significant constrains for evolutive renderings, were provided by chemical and mineralogical record of clastic sedimentary rocks because of their conditioning by factors such as source rock features, weathering, sorting processes during transport and sedimentation, and postdepositional diagenetic reactions (e.g. TAYLOR \& McLENNAN, 1985; McLennan, 1989; McLennan et alii, 1993; Cullers, 1994a, b, 1995; Cullers \& Podkovyrov, 2002; Critelli et alii, 2008; PERRI et alii, 2012a, b; CoRRAdo et alii, 2019; SMERAgLIA et alii, 2019; AldEGa et alii, 2020).

On the contrary a detailed facies analysis of the most southern Apennine turbidite deposits is lacking, apart from researches on single depositional units (see for example Pescatore et alii, 1980; Boiano, 1997; Butler \& TAVARnElli, 2006; CASCIANO et alii, 2019 for the Gorgoglione Flysch; Milli \& Moscatelli, 2000, for the Salto and Val di 
Varri Turbidite Complex; MiLli, 2015 for the S. Bartolomeo Flysch). Consequently, several problems remain relatively unresolved for some of these turbidite successions: i) the facies description and related in place mechanisms; ii) the relationships between facies and basin topography that modify the local flow conditions; iii) the paleocurrent directions considering the post-Messinian tectonic movements (counter-clockwise rotations) including the Agnone Flysch, which is the subject of this paper. The depositional and compositional features of this Lower Messinian turbidite unit is, in fact, poorly known, with only the exception of the paper by Civitelli \& CoRDA (1988), in which the Authors make a brief description of the lithological and compositional characters, with little focus upon depositional processes and the provenance of this turbidite succession.

The present study combining sedimentological, petrographic and mineralogical observations, represents the first attempt to define facies partition, depositional processes, and sediment provenance of the Agnone Flysch in the context of the southern Apennine foreland basin system. As such this study could help testing previous paleotectonic and paleogeographic models and refine the spatial-temporal evolution of the southern Apennine foreland.

\section{GEOLOGICAL AND PALEOGEOGRAPHIC SETTING}

The Southern Apennines constitute the segment of the Apennine chain extending from the southern AbruzziMolise region to Sicily through the Calabrian Arc (Fig. 1). It is characterized by a complex geological structure formed by the superposition of several tectonic units. Each of these units is constituted by a single thrust sheet, or by a group of thrust sheets, which are separated by long thrust flat with low cutoff angles at the footwall (PATACCA \& SCANDONE, 2007 with references therein).

These tectonic units are formed by thick stratigraphic successions in which several lithostratigraphic units derived by the deformation of the same paleogeographic domain occur (Patacca \& Scandone, 2007; Vitale \& CIARCIA, 2013). Most of the authors agree that two main geodynamic phases are responsible for the construction of the Southern Apennines (DEwEy et alii, 1989; FACCENNA et alii, 2001): the Late Oligocene-Middle Miocene phase that was coeval with the opening of the Ligurian-Provencal back-arc basin, and the Tortonian-Pleistocene phase that was coeval with the opening of the Tyrrhenian back-arc basin. Single orogenic pulses were also recognized at (1) Late Burdigalian; (2) Langhian/Serravallian boundary; (3) Middle-Late Serravallian; (4) Middle-Late Tortonian; (5) Tortonian/Messinian boundary; (6) Late Messinian; (7) Zanclean; and (8) Early Piacenzian (Vitale \& Ciarcia, 2013).

During the years, various paleogeographic reconstruction of the southern Apennine area before and after the two main deformations phases have been proposed, which foreseed a variable number of carbonate platforms separated by more or less deep basins (D'Argenio et alii, 1973; Mostardini \& MERLINI, 1986; Santo \& Sgrosso, 1987; Casero et alii, 1988; Marsella et alii, 1995; Mazzoli et alii, 2001; Patacca \& Scandone, 2007; Bonardi et alii, 2009; Scrocca, 2010; Vitale \& Ciarcia, 2013 with references therein; Fig. 2). The deformation of these domains led to the build-up of structural-stratigraphic units that have their own evolutionary tectonic history different from the overlying and underlying units (PATACCA \& Scandone, 2007; Mazzoli et alii, 2008 Bonardi et alii, 2009; Vitale \& CiaRcia, 2013 and references therein). On this basis these Authors recognized several tectonic units forming the southern Apennine thrust belt that derived by the deformation of the following domains (Fig. 2): i) Internal Nappes; they represent the westernmost domain that include all the ophiolite-bearing Ligurian Units and the Sicilide Unit with a basement constituted by oceanic or a thinned continental crust; ii) Apenninic Platform; it constitutes the main structure forming the carbonate massifs of the Campania-Lucania Apennine and includes several carbonate units separated by thrust surfaces; iii) Lagonegro-Molise Basin; this wide basin was located between the Apenninic Platform and the Apulia Platform and includes several pelagic successions and turbidite units (e.g., Agnone Flysch); iv) Simbruini-Matese Platform; it includes an undifferentiated thick succession of shallowwater carbonate that consists of several thrust sheets; v) Western Marsica Platform; it is constituted by shallowwater Mesozoic carbonate deposits, on top of which the foreland hemipelagic sedimentation persisted until the early Messinian (see CosEntino et alii, 1997); vi) Gran Sasso-Genzana, Montagna dei Fiori basinal realms and related marginal areas; such domain is characterized by two main tectonic units (Gran Sasso-Genzana Unit and Montagna dei Fiori Unit) constituted by thick basinal and shallow water Meso-Cenozoic carbonate deposits on top of which lower Messinian turbidite deposits or Messinian resedimented gypsarenits deposits occur respectively; vii) Apulia Platform; it includes several tectonic units mainly constituted by shallow-water and deep-water carbonate deposits. In Fig. 2 these different domains are distributed from west to east in the Central and Southern Apennines and are incorporated in the mountain chain during its eastward progressive migration. These movements were reconstructed by using paleogeographic maps, the spatial and temporal distribution of foredeep deposits and magmatic rocks and through the paleomagnetic data indicating a counterclockwise rotation of the Apennine successions of about $60^{\circ}-70^{\circ}$ from the Late Oligocene to Recent (see Michard et alii, 2002; CifElli et alii, 2007; Mattei et alii, 2007; Patacca \& Scandone, 2007; Bonardi $e t$ alii, 2009; LuSTRINO et alii, 2009; HANDY et alii, 2010; ACCAINO et alii, 2011; Vitale \& CiARCIA, 2013).

As regards the deposits of the Agnone Flysch, they are part of the Agnone Unit, which in turn constitutes one of the tectonic units deriving from the deformation of the Lagonegro-Molise Basin. The other tectonic units are those of Frosolone, Tufillo-Serra Palazzo, and Daunia. The literature data indicate that the succession of the Frosolone Unit was deposited adjacent to the SimbruiniMatese platform (Clermonte \& Pironon, 1979; Scrocca et alii, 1995; Scrocca, 1996; Patacca \& Scandone, 2007); moreover data provided by these last Authors also suggest a physical contiguity between the Frosolone and Agnone domains and between the Tufillo-Serra Palazzo and Daunia, as well as between Agnone and Tufillo-Serra Palazzo (Patacca \& Scandone, 2007; Vitale \& Ciarcia, 2013). Such paleogeographic relationships are evidenced in the palinspastic restorations reported in Fig. 2, indicating that 


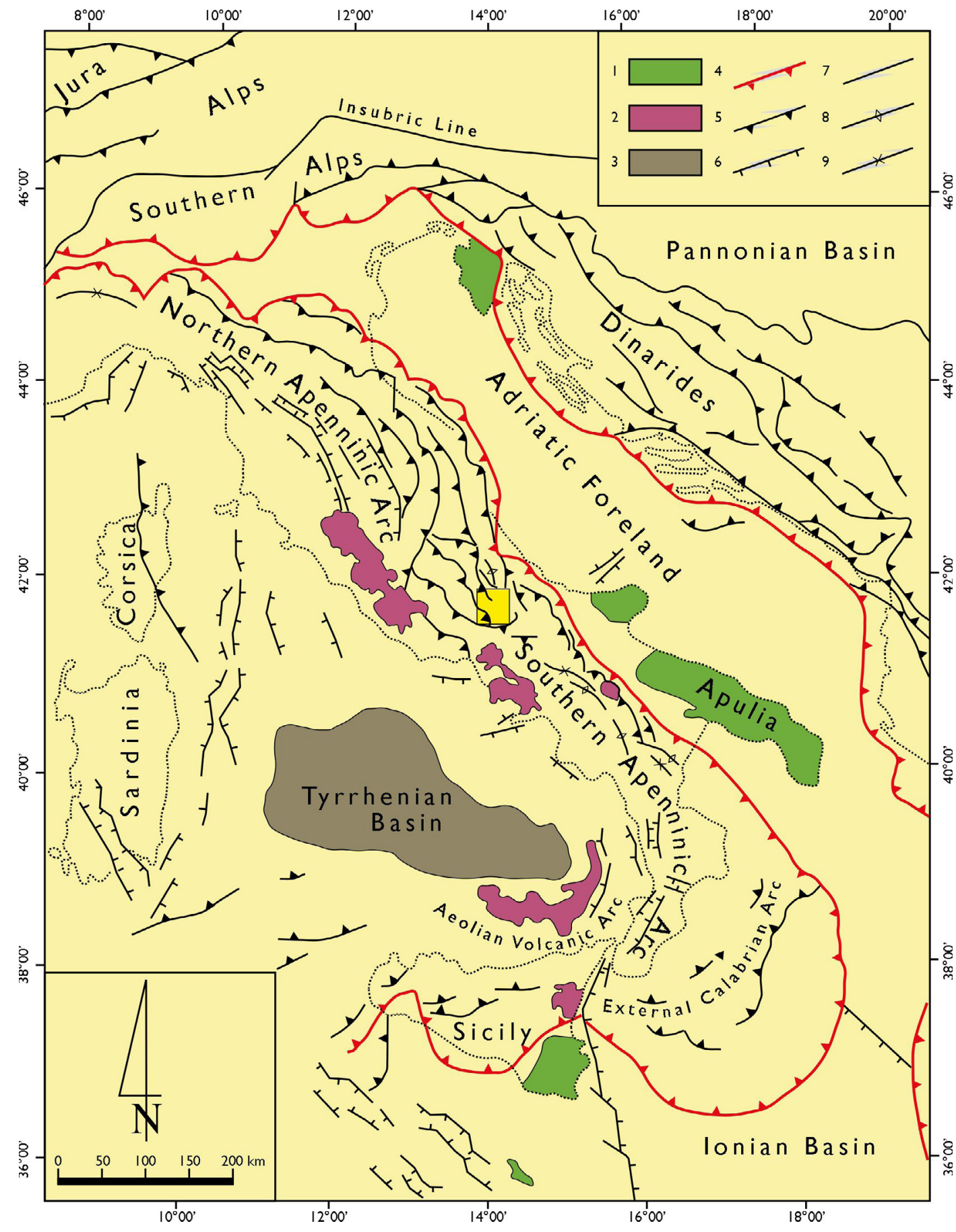

Fig. 1 - Structural sketch of the Italian Peninsula, showing its subdivision into Northern and Southern Apenninic Arcs. 1) Mesozoic-Tertiary carbonates of the foreland areas; 2) Main Quaternary volcanic complexes; 3) Sector of the Tyrrhenian Basin floored by oceanic or thinned continental crust; 4) Front of the Maghrebides, Apennines, Southern Alps and Dinarides; 5) Other thrusts including the front of the Alps; 6) Normal faults; 7) Strike-slip faults 8) Anticline axis; 9) Syncline axis. (Redrawn from PatACCA \& SCANDONE, 2007) the Simbruini-Matese platform was part of the foredeep basin during the Late Tortonian and would be incorporated into the thrust belt during the early Messinian (PAтAсCA et alii, 1991; Cipollari \& Cosentino, 1995; Cipollari et alii, 1999; Billi et alii, 2006; Cosentino \& Cipollari, 2012. The latter interpretation is still the subject of controversy, since other authors consider only the inner portion of the Simbruini-Ernici ridge as deposited in isolated wedge-top basins in the early Messinian, whereas the eastern part of the Simbruini ridge and the adjacent Roveto Valley and Marsica area was still a portion of the foredeep affected by extensional tectonics, where carbonate clastic deposits (Brecce della Renga fm.) and northwestern-derived siliciclastic turbidite deposits (Valle del Salto and Val di Varri turbiditic complex) sedimented (Milli \& Moscatelli, 2000, 2001; Bigi et alii, 2003; CompagnONI et alii, 2005; Critelli et alii, 2007; Cavinato et alii, 2012; Marini et alii, 2012; CARMinati et alii, 2014; FABBI, 2016; FABBI \& Rossi, 2014; FabBi \& Santantonio, 2019). Based on these data and coherently with the interpretation of the above authors we retain that in the early Messinian the Simbruini and Marsica sector would represented a structural high developed inside the foredeep, separating the northern sector of this basin where the north and northwestern derived siliciclastic turbidite flow impacted against this structural high (see Milli \& Moscatelli, 2001; Bigi et alii, 

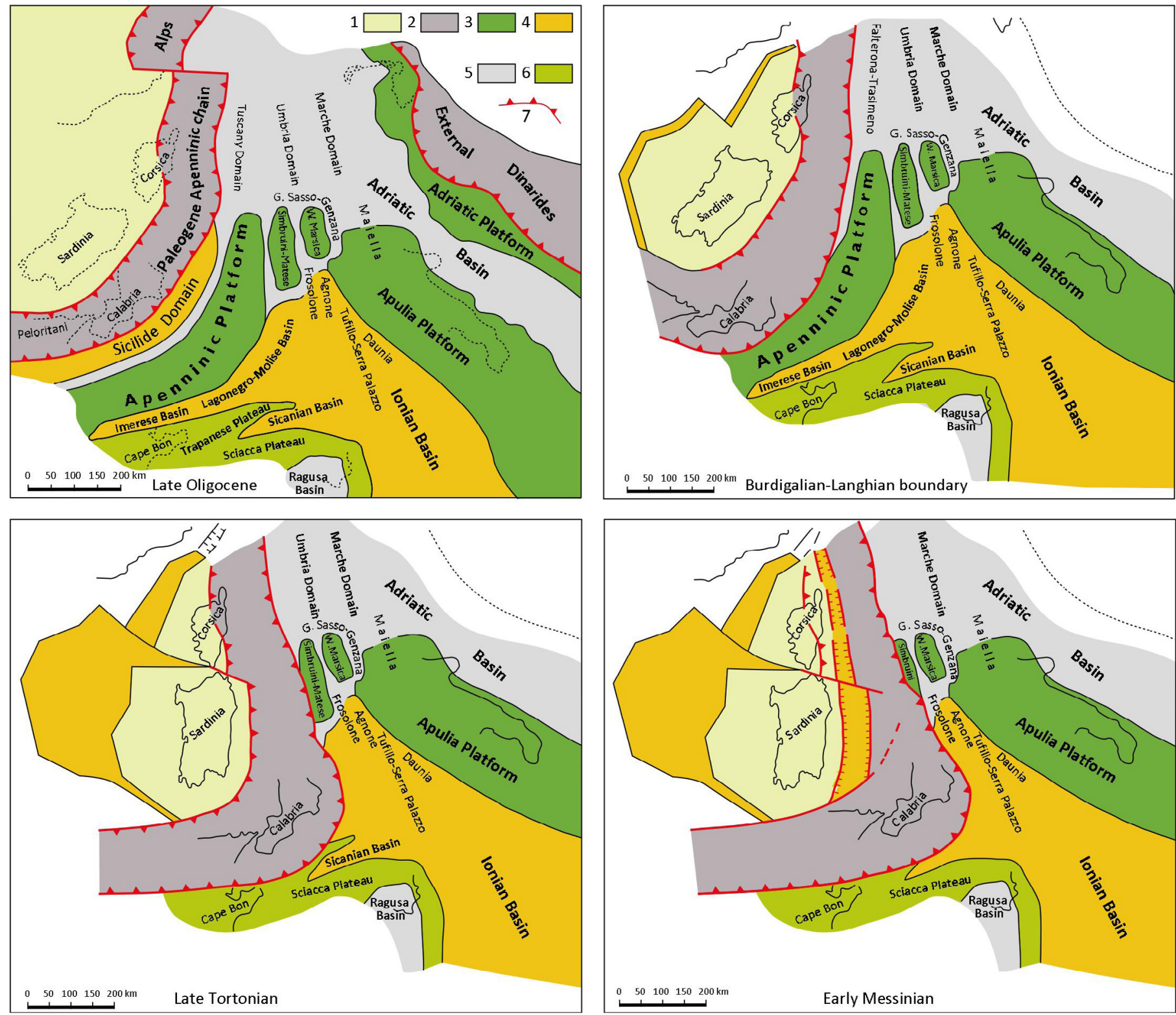

Fig. 2 - Palinspastic restoration of the Central Mediterranean area from Late Oligocene to early Messinian times. Legend: 1) European foreland 2) Apenninic chains; 3) Shallow-water carbonate platforms; 4) Deep-water basins floored by oceanic or thinned continental crust; 5) Basinal areas with isolated structural highs; 6) Pelagic plateaux; 7) Front of the orogenic belts. (Redrawn and partially modified from Patacca \& SCANDONE, 2007).

2003; CRITELLI et alii, 2007), from the southern sector of the foredeep (the Lagonegro-Molise Basin) where during the early Messinian the Frosolone and the Agnone sandstones were deposited; both these units onlapped onto the southern margin of this structural high.

These considerations suggest that during the lower Messinian the wide Lagonegro-Molise foredeep basin may have had a more articulated morphology with a series of subbasin, north-south oriented and separated, probably, by incipient thrusts, where the turbidite deposits of the Frosolone and Agnone units, and of Tufillo Serra-Palazzo and Daunia units sedimented. The turbidite deposits related to these last two units are represented, by the Olmi and Treste Formations, respectively; these formations have smaller thicknesses (a few hundred meters), finer sandy grain-size, and a greater content of mudstone sediments
(Patacca \& Scandone, 2007). This suggests and confirms a deposition of these units in the most eastern and external sector of the Lagonegro-Molise foredeep basin, just near to the western margin of the Apulia platform, on which these deposits onlapped.

\section{THE STRATIGRAPHY OF THE AGNONE FLYSCH}

The Agnone Flysch constitutes the upper portion of the Agnone tectonic unit, which is formed, from the bottom upwards (PATACCA et alii, 1991), by the Varicoloured Clays (upper Oligocene? - Burdigalian), by the pre-flysch carbonate deposits (Langhian-upper Tortonian) and by the turbidite deposits of the Agnone Flysch (lower Messinian). The stratigraphic relationships between these 
formations are schematically drawn in Fig. 3, showing the onlap of Agnone Flysch onto the raised northern margin of the basin. Although not recorded in the outcrops, onlap relationships between the Agnone Flysch and the substratum are also hypothesized along the western margin of the basin. From this last sector resedimented carbonate debris, locally represented by large olistolith, originated. These carbonate debris, that occur at different heights within the turbidite deposits, were derived from dismantling of strongly tectonized sectors of the carbonate platform bordering the foredeep basin on the western and northern sectors.

Stratigraphic, sedimentological, and petrographic data of the Agnone Flysch are very scarce; a detailed facies analysis is lacking, while a relatively recent petrographic analysis on the sandstones was carried out during the survey of the Geological Map 1:50.000 Sheet 393 "Trivento" Italian Geological Survey (see CRITELLI, 2015). Previous information is presented in the paper of Civitelli \& CORDA (1988) but with particular reference to heavy minerals. Further details on this lithostratigraphic unit occur in Patacca et alii (1991) and Patacca \& Scandone (2007), which subdivide this succession into three members, from older to younger, the Verrino member (VM), the Poggio Villanelle member (PVM), and the Sente member (SM) on the basis of outcrop data and on the stratigraphy of the Belmonte del Sannio 1 well (Fig. 4). The same Authors, on the basis of the microfaunistic and nannofloristic assemblages, indicate that the deposition of this unit occurred during the early Messinian pre-salinity crisis.

The Verrino member (about $1200 \mathrm{~m}$ thick) is characterized by variable thickness and laterally continuous mudstone-sandstone beds, with several intercalations of bioclastic calcarenite beds. The thicker bioclastic carbonate layers show, locally, the presence of small flutes and groove casts indicating a provenance of the flows from the northwestern and western sectors (Fig. 5). This is consistent with what has been found by
Civitelli \& CoRda (1988), which show that most of the calcarenite beds occurring in this member, as well as in the Poggio Villanelle member, derive from the carbonate platforms that were present on the western and northern margin of the Lagonegro-Molise basin. Locally siliciclastic and carbonate particles are mixed giving rise to hybrid arenite (sensu ZuFFA, 1980). The Verrino member shows a coarsening- and thickening-upward trend, being this portion of the Agnone Flysch characterized by a mudstonedominated basal portion passing upward into a sandstonedominated portion that continues in the lower part (about $300 \mathrm{~m}$ thick) of the overlying Poggio Villanelle member.

The latter (about $1100 \mathrm{~m}$ thick) is characterized by less regular and more discontinuous sandstone beds that can reach thicknesses of about $10 \mathrm{~m}$ in the lower portion of this member. Overall, the Poggio Villanelle member is characterized by thick and thin sandstone-mudstone couplets with complete and incomplete Bouma sequence, organized in thinning- and fining-upward units, about 100 $m$ thick; the general thinning- and fining upward trend characterizing this member continues in the overlying Sente member (Fig. 4). The Poggio Villanelle member, like the Verrino member, shows also the presence of calcarenite and calcirudite intercalations, as well as scattered blocks of large olistolith consisting of bryozoan and Lithothamnium limestones, rudistid limestones, Lepidocyclina limestones and Orbulina marly limestones (see also Patacca et alii, 1991).

The Sente member (about $400 \mathrm{~m}$ thick) crops out only in a few sectors of the investigated area and its most complete succession occurs in the Belmonte del Sannio 1 well. The deposits of this member are essentially characterized by thin sandstone-mudstone couplets with incomplete Bouma sequence that are organized to confer to this unit a general thinning- and fining-upward trend.

On the basis of the previous considerations the vertical distribution of the three members with their lithofacies associations allows us to broadly reconstruct

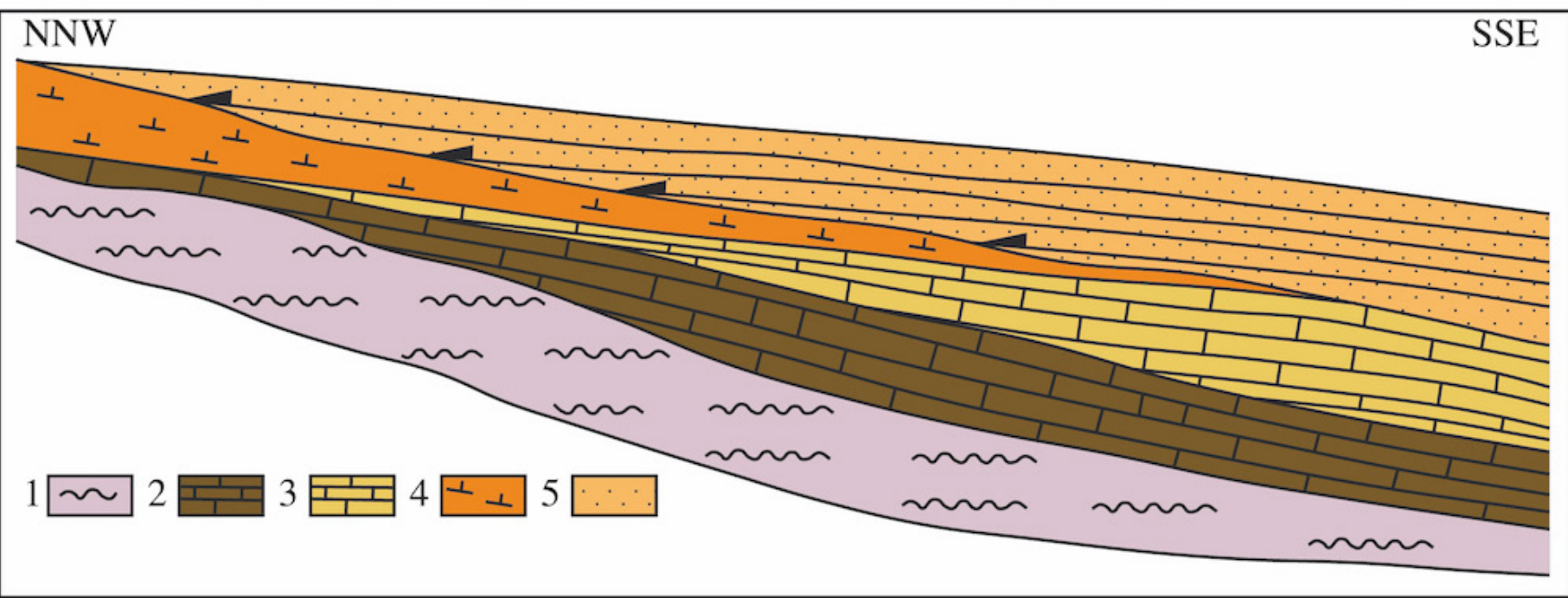

Fig. 3 - Stratigraphic relationships between the Agnone Flysch and underlying formations constituting the Agnone tectonic unit. This scheme has been reconstructed on the basis of literature data (Di Bucci 1995) and field observations. The lithostratigraphic units are those described by Di Bucci (1995): 1) Varicoloured Clay (upper Oligocene?- Burdigalian); 2) Calcirudites and calcarenites of the Pizzoferrato lithostratigraphic Unit (lower Miocene); 3) Marls, marly limestones and calcarenites of the M. Campo Unit (upper Langhian-upper Tortonian; 4) Orbulina calcareous marls (Serravallian-Tortonian); 5) Agnone Flysch (uppermost Tortonian-lower Messinian). 


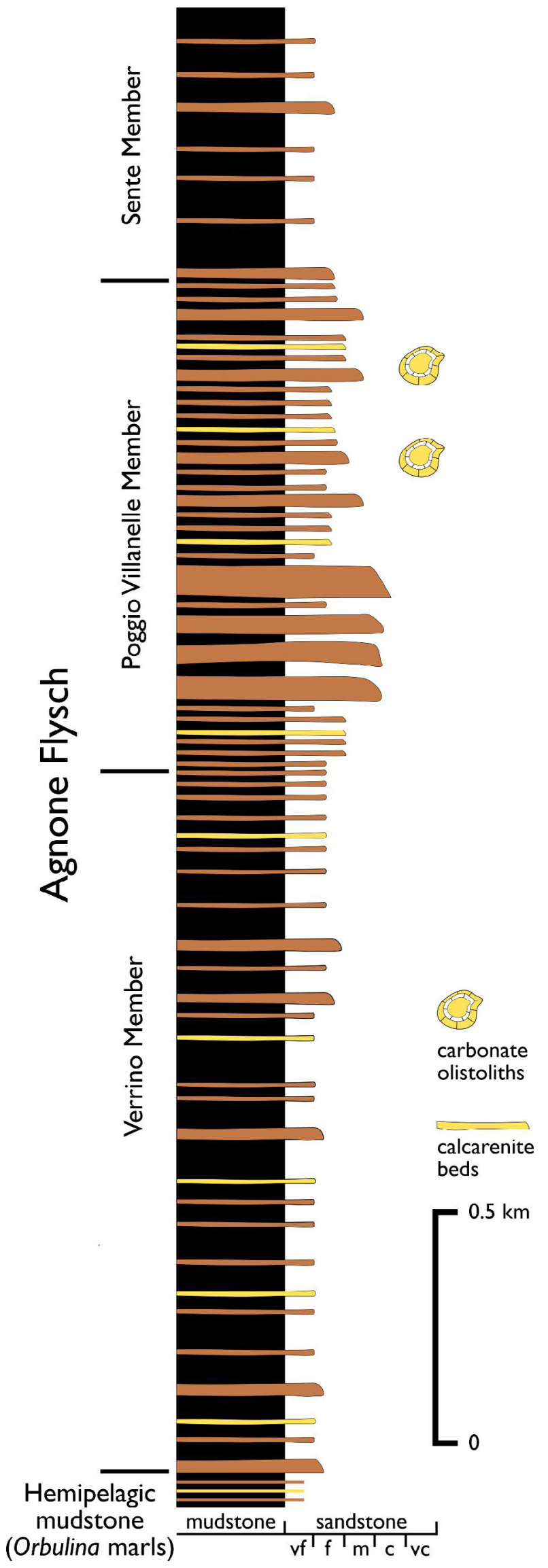

Fig. 4 - Stratigraphic log of the Agnone Flysch showing the three members and their internal stratigraphic organization (see text for more explanation). the evolutionary trend of the Agnone Flysch in the Molise area. The basal portion of this succession is made up of a few meters thick hemipelagic mudstone with abundant planktonic foraminifers whose assemblage indicates an early Messinian age (PATACCA et alii, 1991; AMORE, 1992). Upward the increases in frequency and thickness of the sandy and silty beds constituting the Verrino member and the initial part of the Poggio Villanelle member, reflects the increasingly arrival of turbidite flows that deposited these sediments in the distal sector of the basin (lobes depositional zone). This indicates that the Verrino member and initial part of Poggio Villanelle member record a clear progradational trend (forestepping) of the Agnone turbidite system, which was followed by a phase of retrogradation and sediment starvation of the system during the deposition of the upper portion of the Poggio Villanelle and Sente members.

The sector of the Agnone Basin closest to the carbonate structures records, both in the basal mudstone hemipelagic facies and in the turbidite sandstone-mudstone unit, the presence of bioclastic calcarenite and calcirudite beds, whose deposition occurred through gravity flows coming from western and north-western sectors of the LagonegroMolise Basin where carbonate platforms were present.

\section{SAMPLING AND METHODS}

The investigated Agnone Flysch succession crops out in the Molise region, in the north-east of Isernia area. The area includes the villages of Agnone, Castelverrino, Poggio Sannita, and Pietrabbondante (Figs. 6 and 7). In this sector, the Agnone turbidite deposits form a homocline with beds striking from $\mathrm{N} 20^{\circ}$ to $\mathrm{N} 40^{\circ}$, a dip direction between $110^{\circ}$ to $130^{\circ}$ (towards ESE and SE), and a dip angle between $30^{\circ}$ and $40^{\circ}$.

In order to define the main sedimentological characters of the Agnone Flysch, 10 stratigraphic sections for a total thickness of about $1100 \mathrm{~m}$ were measured (Fig. 8). Turbidite facies have been distinguished according to grain size, texture, sedimentary structures, and paleocurrents as observed in the field; the paleocurrent data were also modified in their orientation in order to take into account the counterclockwise rotation of this area after the Messinian time. Two correlation panels were constructed in order to better define the geometry of the sandstone bodies and the facies relationships (Figs. 22 and 23).

In the attempt to reconstruct the stratigraphic relationships between the Agnone Flysch and the immediately underlying stratigraphic units (see also Fig. 3), the stratigraphy of the wells Ateleta1 (AT1), Ateleta2 (AT2), Belmonte del Sannio1 (BS1), Messer Marino1 (MM1), Pescopennataro1 (PE1), Pescopennataro2 (PE2), and Rossello1 (RS1) provided by the VIDEPI Project, and Lago Saletta1 (LS1), provided by ENI, drilled in the area for hydrocarbon exploration were utilized (Fig. 7). Two correlation panels oriented parallel (NW-SE) and perpendicularly (WSW-ENE) to the direction of the paleocurrents respectively were constructed allowing us to broadly define the possible morphology of the basin at the time of the Agnone Flysch deposition (Fig. 24).

The 10 logged sections were also sampled in order to perform a detailed petrographic analysis on a total of 67 samples (44 sandstone and 23 mudrock samples). In 

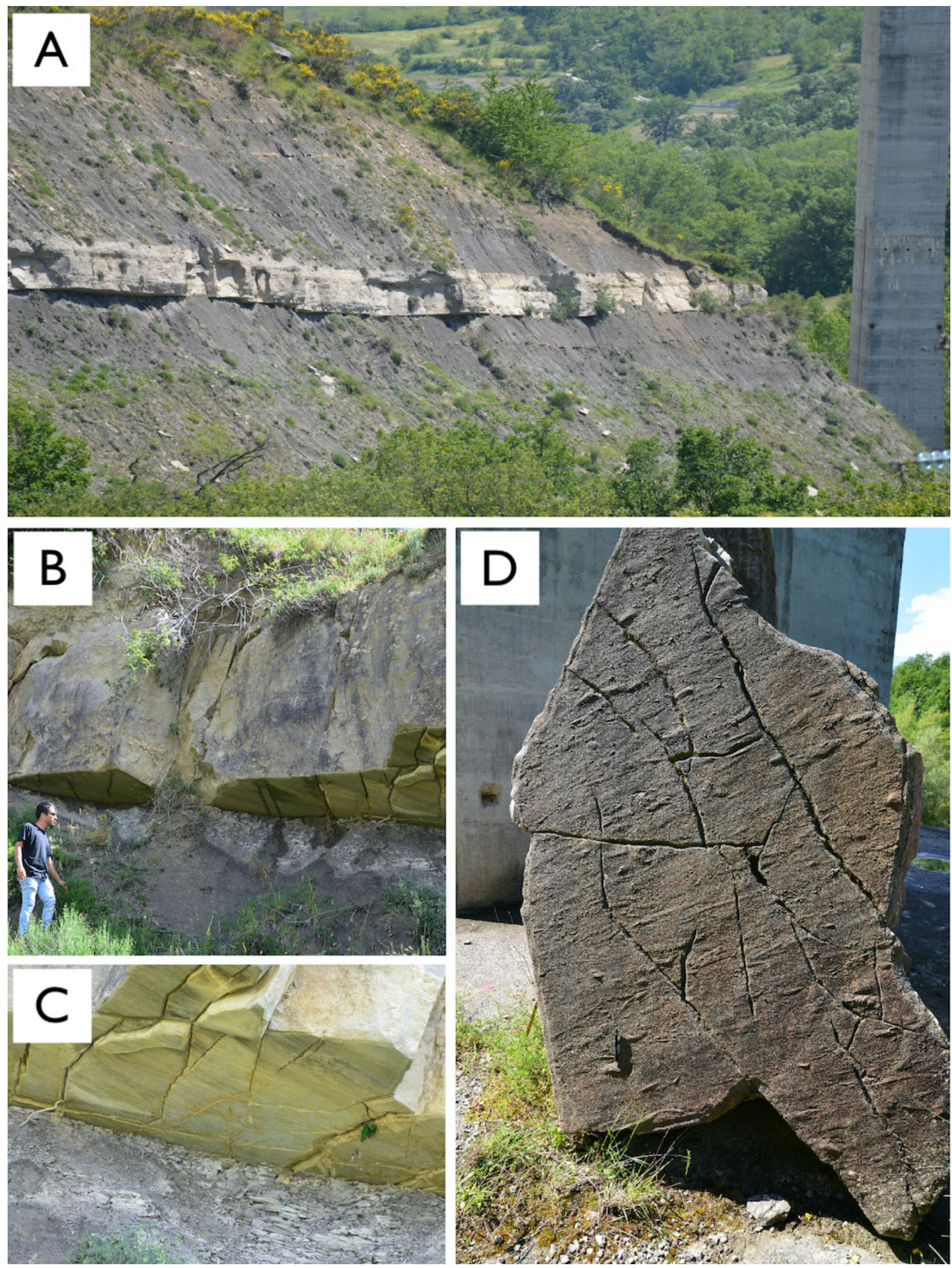

Fig. 5 - A) Thick calcarenite bed intercalated within the mudstone-sandstone deposits of the Verrino member. B) Detail of the calcarenite bed at the base of which flutes, grooves and parting lineations occur (C and D). 


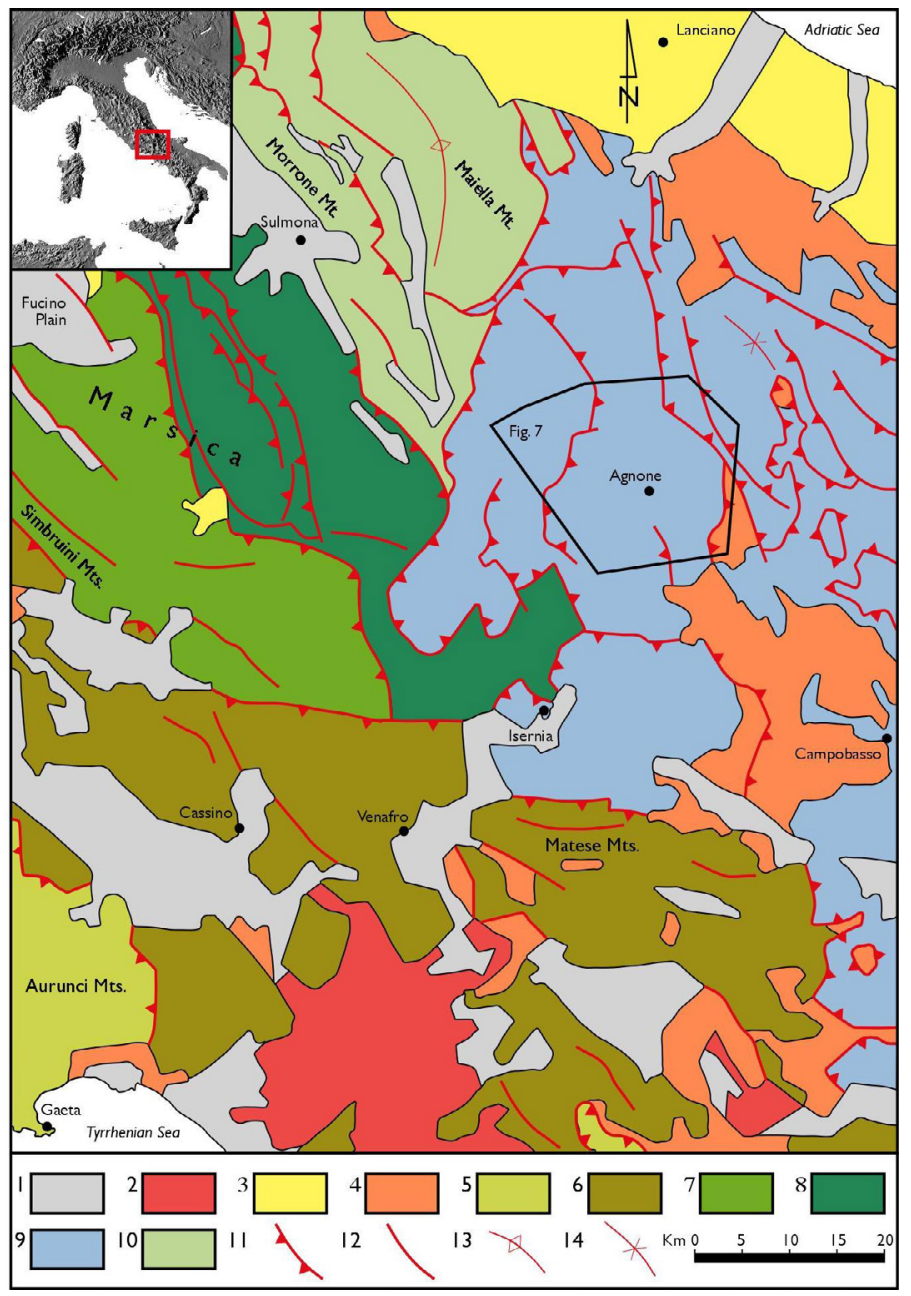

Fig. 6 - Simplified geological-structural map showing the main tectonic units of the Southern Apennines in the area surrounding the investigated sector (redrawn and modified by Patacca \& Scandone, 2007). 1 = Continental and shallow marine deposits (Quaternary); $2=$ Volcanic deposits (Middle Pleistocene to Holocene); 3 = Continental and marine deposits (Lower-Middle Pleistocene); 4 = Thrust-sheet-top terrigenous deposits (Miocene-Pliocene); 5 = Tectonic units derived from the Apenninic Platform; $6=$ Tectonic units derived from the Simbruini-Matese Platform; $7=$ Tectonic units derived from the Western Marsica Platform; 8 = Tectonic units derived from the Gran Sasso- Genzana and related marginal areas; $9=$ Tectonic units derived from the Lagonegro-Molise Basin; $10=$ Tectonic units derived from the Apulia Platform; 11 = Thrusts; 12 = Faults; 13 = Anticline axis; 14 = Sincline axis.

particular 9 sandstone samples are representative of the Verrino member (VM) and 35 samples are representative of the Poggio Villanelle member (PVM). No samples were collected from the Sente member due to the absence of this member's outcrop in the investigated area. Medium to coarse-grained sandstones were selected for point-count and thin-section analyses. About 300 to 500 points were counted for each thin-section according to the GazziDickinson method to minimize the rock composition dependence on grain size (GAZZI, 1966; DicKInson, 1970; INGERSOLl et alii, 1984; ZuFFA, 1985, 1987). Counted grains were assigned to monomineralic and polymineralic compositional categories and their spatial (extrabasinal versus intrabasinal) and temporal (coeval versus noncoeval) relationships defined using the parameters proposed by
IngERsoll \& SucZeck (1979), ZufFA (1980, 1985), Dickinson (1985), Critelli \& Le Pera (1994) and Caracciolo et alii (2011), and listed in Tab. 1. The results of modal analysis were recalculated using compositional parameters reported in Tab. 2. Calculated grains parameters and point-count results are shown in detail in Tabs. S1 and S2 (see supplementary material). The recalculated modal point in percent of Agnone Flysch sandstones are reported in Tab. S3 (see supplementary material). The optical microscopy allowed to highlight mineral assemblage and petrographic features of sandstones through textural and compositional analysis. Detrital modes were plotted in ternary diagrams and confidence regions of detrital-mode means were calculated using the procedures described by Aitchison (1997); the samples distribution defines two field of variations (Figs. 9, and 10). Confidence regions (90 and $95 \%$ ) were computed using log-ration transformation of compositional data using ' $\mathrm{R}$ ' (a software for statistical computing and graphics) and its software package "Composition" (BoogaArt \& Tolosana-Delgado, 2008; CARACCIOLO et alii, 2012). Geometric means were used, and confidence regions were plotted according to WeLtJE (2002). In addition to QmFLt, QpLvmLsm, and LmLvLs diagrams (Fig. 9), we used RgRsRm and RgRvRm ternary plots, to evaluate phaneritic lithics proportions (Fig. 10). Rg rock fragments are retrieved from counts of monocrystalline quartz, k-feldspar, plagioclase, and phyllosilicate in coarse polycrystalline grains of phaneritic rock fragments ( $\mathrm{Rm}$ and Rv, respectively) added with aphanitic metamorphic $(\mathrm{Lm})$ and volcanic (Lv) lithics fragments; Rs rock fragments correspond to Ls.

A set of 23 mudrock samples were collected for mineralogical analyses: seven samples belong to Verrino member, sixteen samples are representative of Poggio Villanelle member. Mudrock samples were cleaned from weather coats and veined surfaces were removed, subsequently the rocks, were crushed and milled in an agate mortar to a very fine powder. The mineralogy of the whole-rock powder and the fine fractions (clay fraction $<2 \mu \mathrm{m}$ ) was determined by X-ray diffraction (XRD) using Bruker's X-ray Diffractometer D8 Advance at the Università della Calabria (Italy). In addition, through the WINFIT computer program (KRUMM, 1996) that measures peak areas, semiquantitative mineralogical analysis (e.g., LAVIANO, 1987) of the bulk rock was carried out on random powders (Tab. 3). The strongest reflection of each mineral was considered, except for quartz. For the latter, the peak at $4.26 \AA$ was considered instead of that at $3.34 \AA$ because its overlap on the values of the $10 \AA$-minerals and mixed layer series of clays. The amount of phyllosilicates was estimated measuring the $4.5 \AA$ peak area. To identify the percentage of phyllosilicates in the bulk rock the diffraction profile of the random powder was observed and in it three areal divisions (peak areas) was considered, as follows: 10-15 $\AA$ (I/S = Illite/Smectite mixed layers + Chl/ $\mathrm{S}=$ chlorite/smectite mixed layers), $10 \AA$ (illite+micas), and $7 \AA$ (kaolinite+chlorite) minerals (e.g., CaVAlCANTE et alii, 2007; Perri, 2008; PERri et alii, 2011). Through some special laboratory techniques for sample preparation and to better distinguish the clay minerals present in the mixed layer packages the whole rock powders, in particular $<2$ $\mu \mathrm{m}$ grain-size fraction was separated by settling in distilled water and then a concentration of $4-10 \mathrm{mg} / \mathrm{cm}^{2}$ was obtained by evaporation of clay-water (LEZZERINI et alii, 


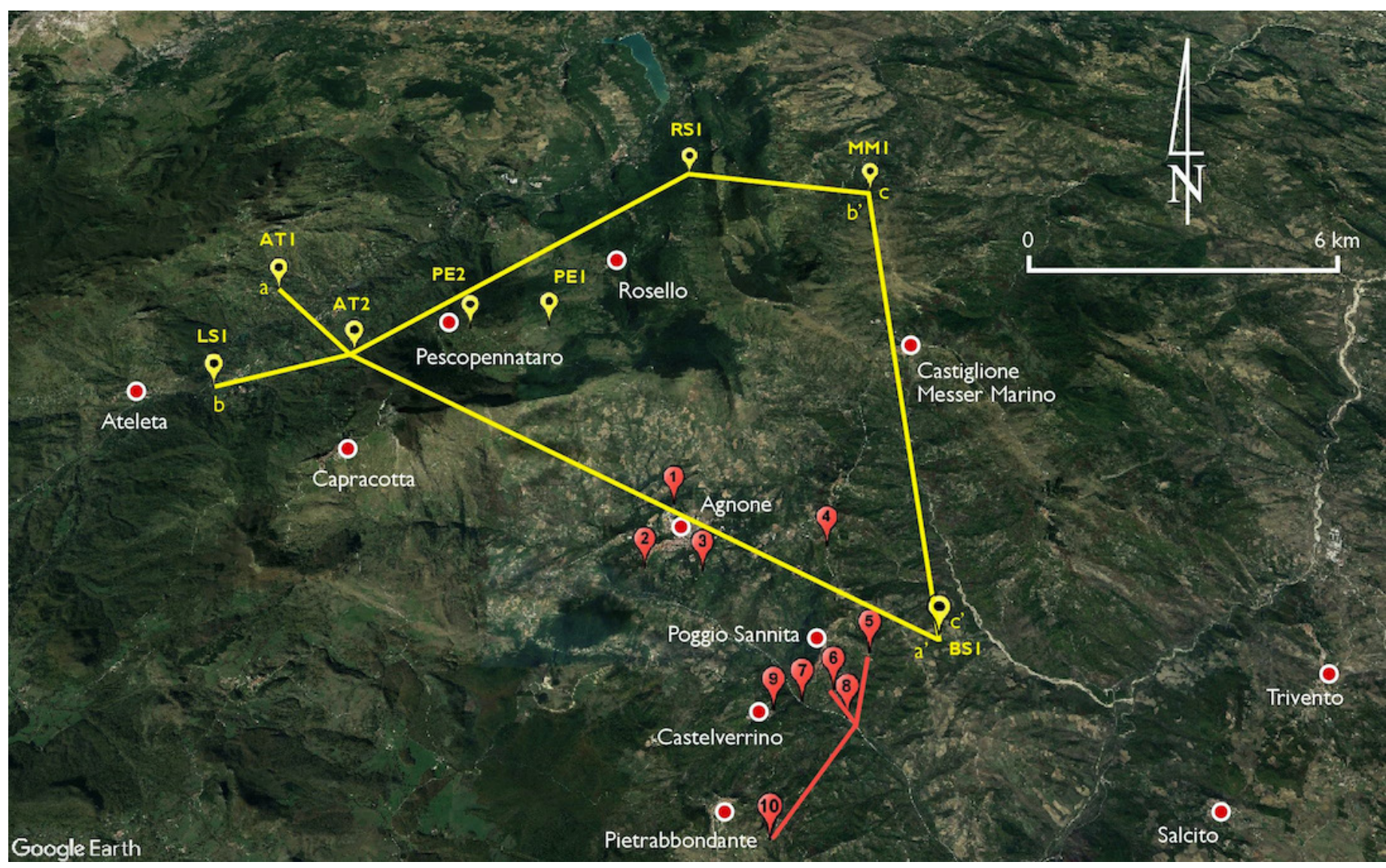

Fig. 7 - Satellite image of the investigated area showing: 1) the positions of the measured stratigraphic logs and the tracks of the correlation panels of figure 22 and 23 (in red); 2) the position of the exploration wells Lago Saletta 1 (LS1), Ateleta 1 (AT1), Ateleta 2 (AT2), Pescopennataro 1 (PE1), Pescopennataro 2 (PE2); Rosello 1 (RS1), Messer Marino 1 (MM1), Belmonte del Sannio 1 (BS1) and the tracks of the stratigraphic cross-section of figure 24 (in yellow).

1995). Subsequently, air-dried specimens were glycolated at $60^{\circ} \mathrm{C}$ for 8 hours and heated at $375^{\circ} \mathrm{C}$ for 1 hour (Moore \& REYNOLDS, 1997) and XRD analysis on oriented amounts was carried out again. The percentage of clay minerals in the $<2 \mu \mathrm{m}$ fraction was estimated by measuring the peak areas on diffraction profiles of the glycolated and heated oriented mounts. The percentage of illite (\%I) and stacking order (Reichweite R; JADGOZINSKI, 1949) of the I/S mixed layers were determined on the spectrum of the glycolated specimens using the $\Delta 2 \theta$ method according to Moore \& REYNOLDS (1997).

\section{RESULTS}

\section{SEDIMENTARY FACIES: DESCRIPTION AND INTERPRETATION}

Facies analysis conducted on the Agnone Flysch deposits allowed us to recognize seven main facies that are described and interpreted in terms of depositional processes. They essentially represent the product of downcurrent transformations and deposition of waning and depletive turbidity currents (the concept of facies tract, sensu Mutтi, 1992; Mutтi et alii, 1999, 2003). However, their sedimentary characters suggest a deposition in the lobe depositional zone, although flow modifications induced by sea-floor topography, in turn related to structurally- controlled basin morphology variations and depositional reliefs, allowed the formation of many massive and crosslaminated sandstone beds, and muddy sandstone beds containing mudstone clasts, continental wood fragments and dispersed organic matter.

The facies FA1 is constituted by coarse to mediumgrained sandstones forming thick (1-3 m) lenticular and laterally continuous massive to crude-laminated beds with pervasive dewatering structures (Fig. 11). Locally rounded small clay chips can be found in the thicker sandstone beds suggesting the presence of amalgamation surfaces. The base of FA1 beds is sharp with locally sole marks (flute and groove casts). These beds do not show at the top finegrained deposits. Facies FA1 is interpreted as the product of deposition of a quickly aggrading high concentration basal layer of bipartite turbidity currents with overlying turbulent flows where, depending by the velocity of flow deceleration, massive or thick and thin traction carpets layers are formed (see also Middleton, 1967; ARnotT \& Hand, 1989; Mutti, 1992; Kneller \& Branney, 1995; Mutti et alii, 2003; FALCINI et alii, 2009a, b; TinTERri \& TAGLIAFERri, 2015). The occurrence of dewatering structures is coherent with the rapid deposition of this facies indicating liquified conditions of the flows during deposition and shear from overriding turbulent flow that can produces traction carpets and by-passing of the medium-fine grained sand and mud. This facies transitionally pass, laterally and 


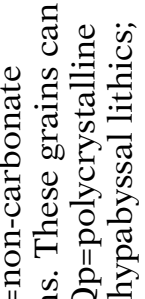

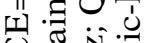

$z$ कू

तิ ส 휴융

讨

ช

事要业

त $\approx 2$

능

ㅇํㅇ 웝

근 $\pi$

ن̈

$z$ 。

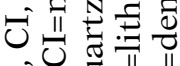

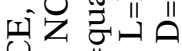

फิ

乙

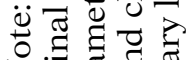

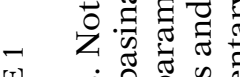

띠

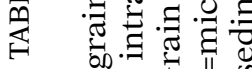

क ज.

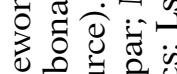

产

II क क

is कू

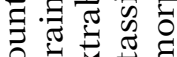

पक की खै

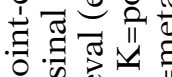

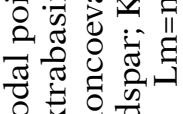

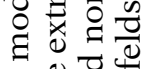

ษ

जิ

बై

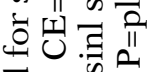

ठ⿹

\& की $\Xi$

중

苟造

记造造

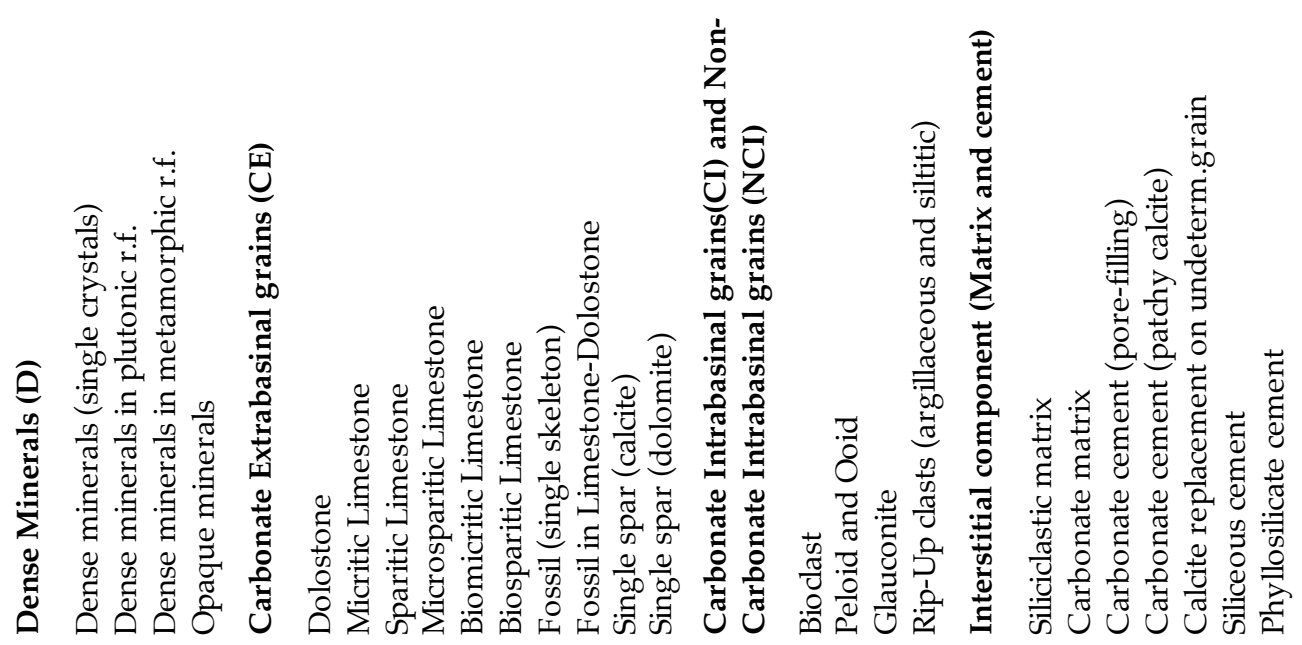

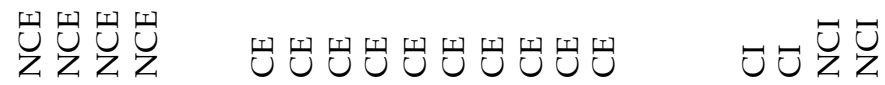

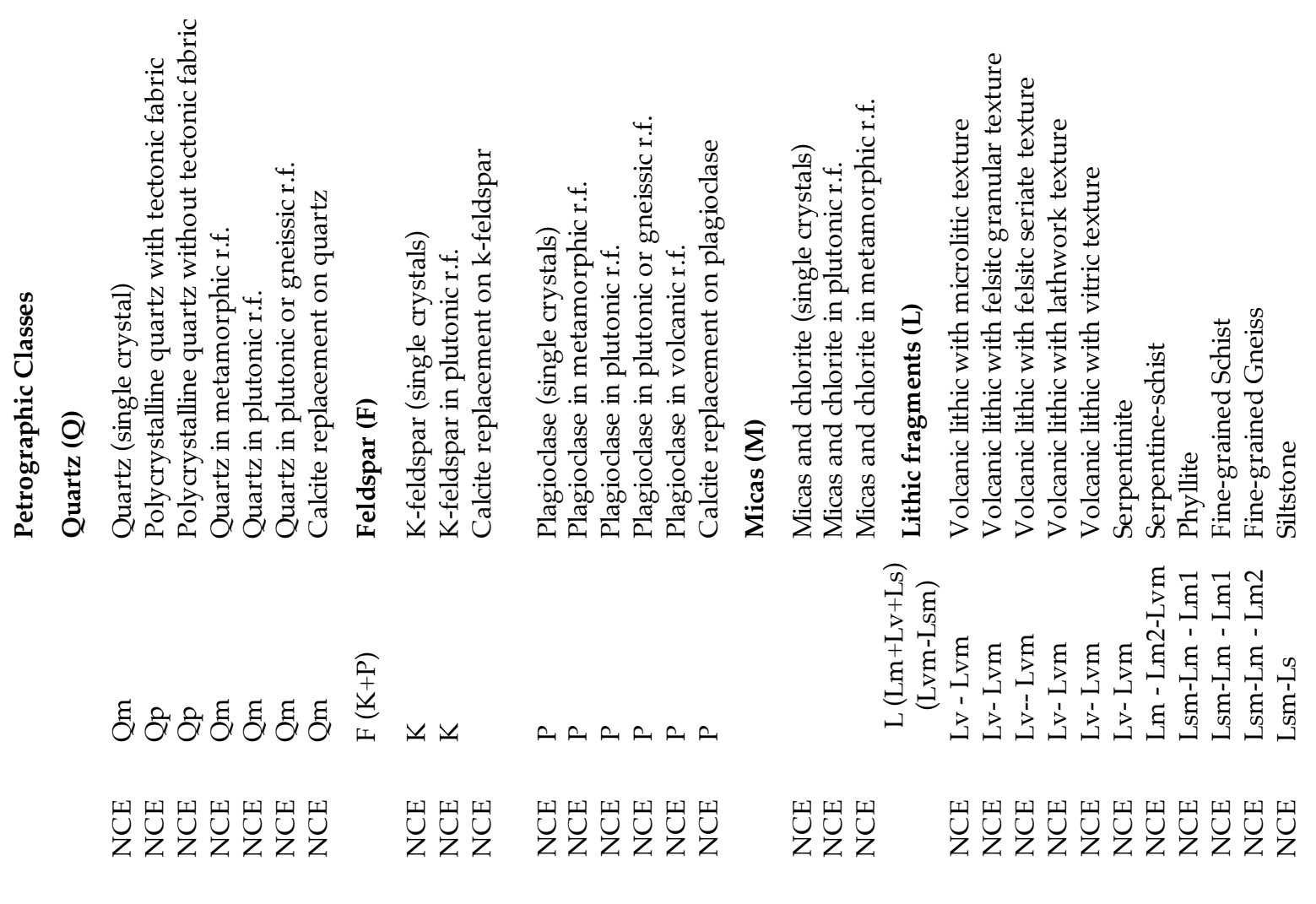


TABLE 2

Compositional parameters used for recalculation.

$\begin{array}{ll}\mathbf{Q t}=\mathbf{Q m}+\mathbf{Q p} & \mathrm{Qt}=\text { total quartzose grains } \\ & \mathrm{Qm}=\text { monocrystalline quartz grains } \\ & \mathrm{Qp}=\text { polycrystalline aphanitic quartzose grains } \\ \mathbf{F}=\mathbf{P}+\mathbf{K} & \mathrm{F}=\text { total feldspar grains } \\ & \mathrm{P}=\text { plagioclase-feldspar grains } \\ & \mathrm{K}=\text { potassium-feldspar grains } \\ & \mathrm{L}=\text { unstable aphanitic lithic grains } \\ & \mathrm{Lm}=\mathbf{L m}+\mathbf{L v}+\mathbf{L s} \quad \mathrm{Lv}=\text { volamorphic lythic grains } \\ & \mathrm{Ls}=\text { sedimentary aphanitic lithic grains plus extrabasinal carbonate grains } \\ & \end{array}$

down current, to the Facies FA2.

The facies FA2 is constituted by medium to finegrained sandstones, forming beds $50-100 \mathrm{~cm}$ thick, with undulated lamination and water escape structures, whose deposition reflects an aggradation with a decreasing rate of fallout with respect to facies FA1 (Fig. 11). Water escape structures occur only in the upper portion of the beds. Differently from the facies FA1, the FA2 shows a sharp or transitionally vertical passage to the fine and very fine sandstones with undulated and convolute lamination of Facies FA4. Beds within the facies FA2 record always a deceleration of the high-density basal portion of bipartite turbidite currents, and the consequently by-passing down current of the more dilute portion.

The facies FA3 forms medium to fine-grained sandstone beds, $15-80 \mathrm{~cm}$ thick, consisting of a massive portion without or with mudstone clasts (Figs. 12 and 13). This portion passes upward to thin or relatively thick laminated fine-grained sandstone with ripples lamination, often deformed to give rise to a convolute lamination. The base of the FA3 beds is erosive and often shows flute and groove casts. Overall, the facies FA3 records a deceleration phase of turbidity currents with the massive portion reflecting a high-fallout rate that suppresses the turbulence, whereas the upper portion of the beds is deposited by traction-plusfallout processes.

When mudstone clasts are present, they vary in dimension from a few millimeters to 10-20 centimeters and occur at different heights within the beds (Figs. 12 and 13). In order to better evaluate the process responsible of their formation and deposition we also considered other parameters (see JoHANsson \& STоw, 1995) such as the sorting, the shape (degree of roundness or angularity), the sphericity, the orientation respect to bedding surfaces, the position within the beds, the lateral extension of the area where the mud casts occur and their concentration. In particular in the Agnone turbidite deposits the mud clasts occur in diverse configuration; they can be isolated, dispersed, or concentrated forming small clouds into the massive portion of the beds or at its top where the boundary between the denser basal flow and the dilute upper turbulent flow occurs (Figs. 12 and 13). In some cases, the mud clasts are found above an irregular scoured depression at the base of the sandstone beds where they are densely concentrated. Rarely, they are also present at the base of sandstone beds showing a marked loading at its base that cause the genesis of flame clasts due to the load impressed by the sandstone bed onto the underlying muddy layer. In all these cases, most of these mud clasts show scanty disaggregation and rounding, so suggesting a local bed erosion and deposition and not a long transport with distance. All these data indicate that the position of mud clasts is controlled by the buoyancy, by the motion into the flow, and finally by the frozen of the flow as was suggested by the model of MutTI \& NiLSEN (1981).

The Facies FA4 constitutes a variant of the facies FA2 being characterized by massive to crude-laminated finevery fine sandstone beds (20-100 cm thick), passing upward to an alternation of undulated and convolute laminae and ripple lamination (Fig. 14). The characters of the FA4 facies with small scale hummocky-like undulated laminae, the presence of flat ripples with rounded crest, and with tangential foreset laminae in opposite direction suggest for these beds an origin related to rebound and reflection processes. Such type of processes can essentially originate along the marginal and frontal slope of the basin and against structural highs although it is not ruled out that these processes can also be active along the lateral slope of depositional lobes. For the type of structures produced by rebound and reflection processes see PICKERING \& HiscotT (1985), Edwards et alii (1994), KNELlER (1995), REMACHa et alii (2005), Muzzi Magalhaes \& Tinterri (2010), Tinterri \& TAGLIAFERRI (2015).

The Facies FA5 is characterized by beds $10-20 \mathrm{~cm}$ thick with a diffuse climbing ripple cross-lamination, often deformed in convolute lamination as result of syn and/ or post-depositional liquefaction associated to upward escapes of pore water (ALLEN, 1982; GLADSTONE et alii, 2018) 


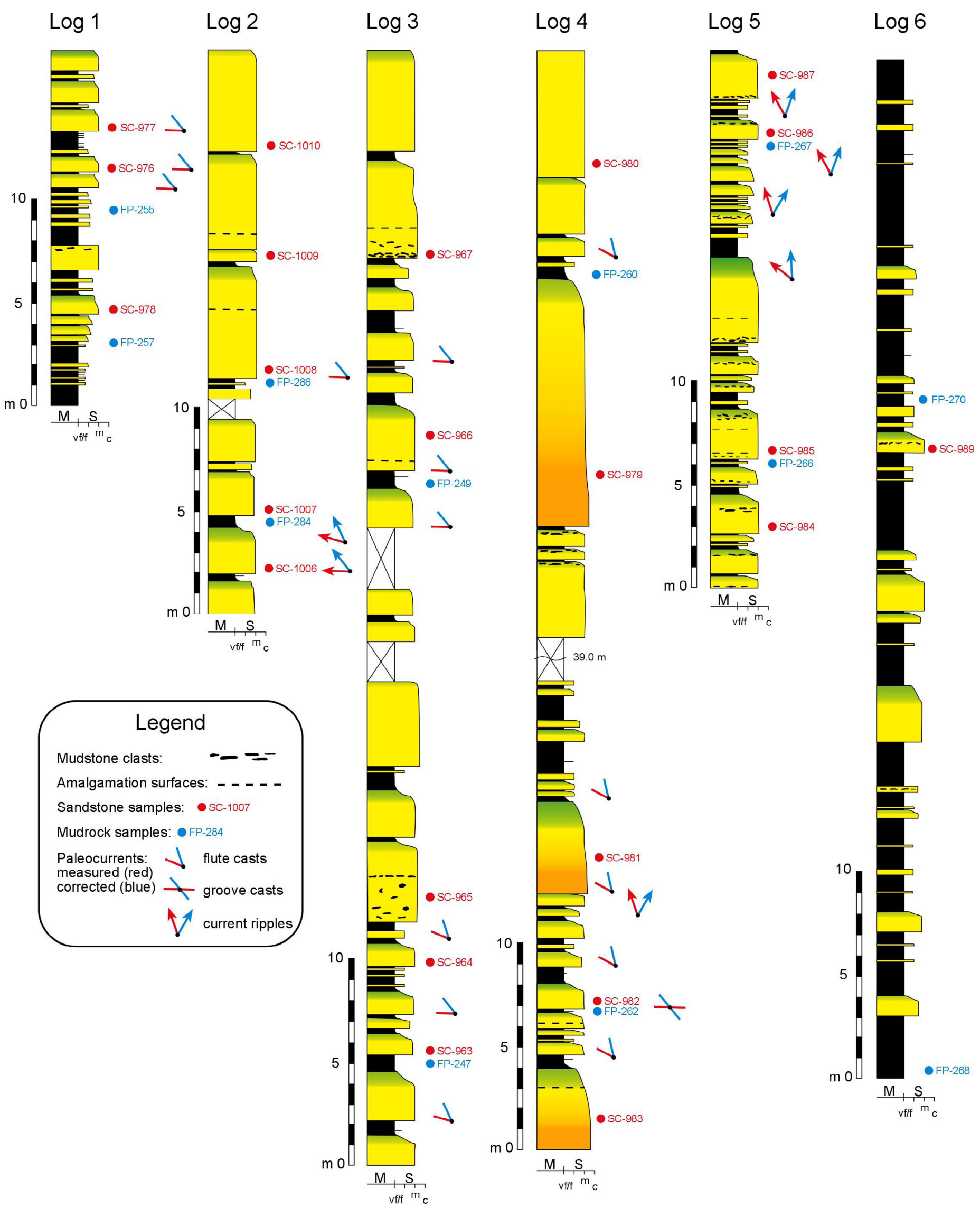

Fig. 8 - Measured stratigraphic logs showing the position of the sandstone and mudrock samples utilized for petrographic/compositional analysis and the measured (red)/corrected (blue) paleocurrents directions considering the post-Messinian counter-clockwise rotation of the investigated area. The logs $1,2,3,4,5,6,8,9$ and 10 were measured in the Poggio Villanelle Member, while the log 7 was measured in the Verrino Member. 


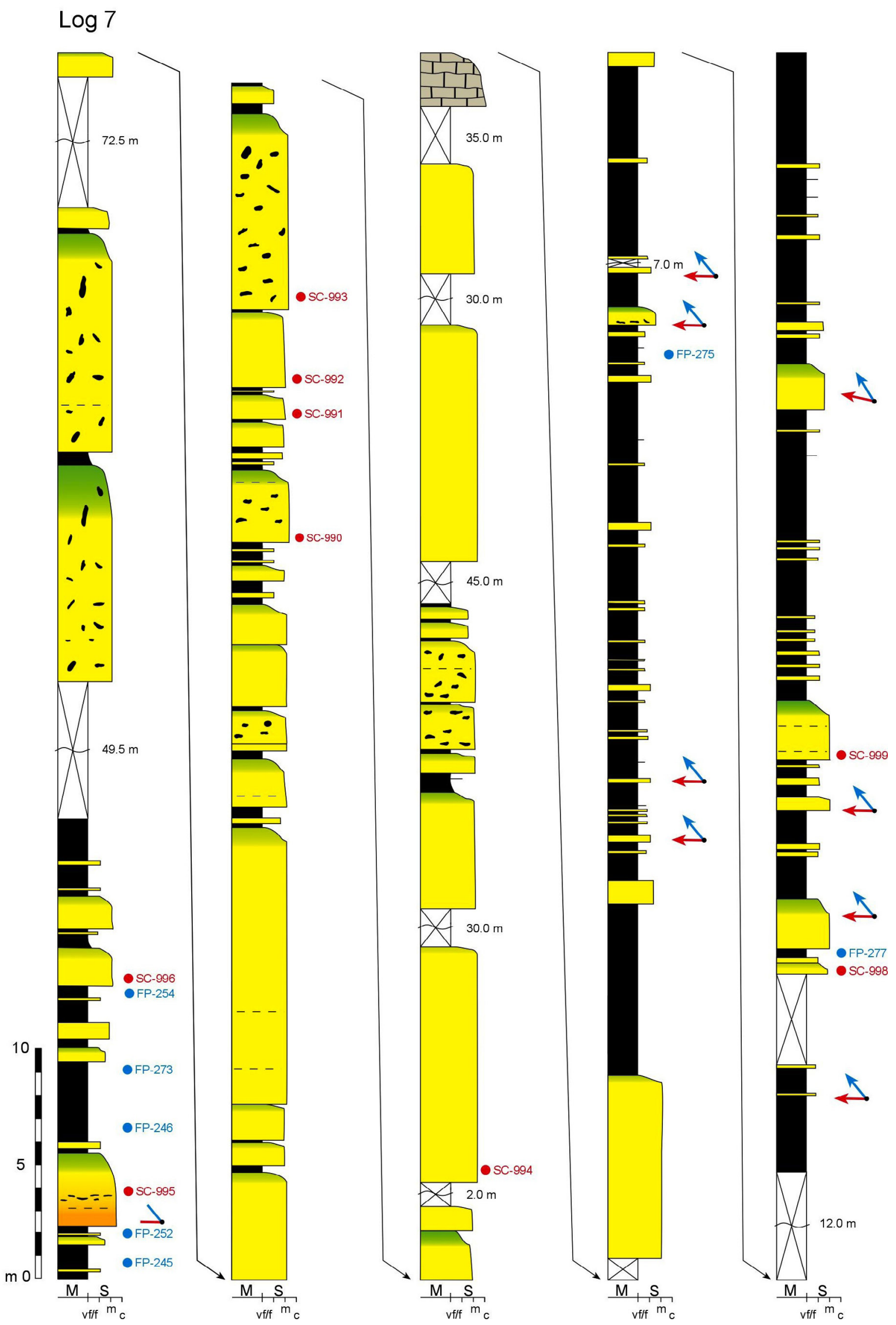

Fig. 8 - continued 

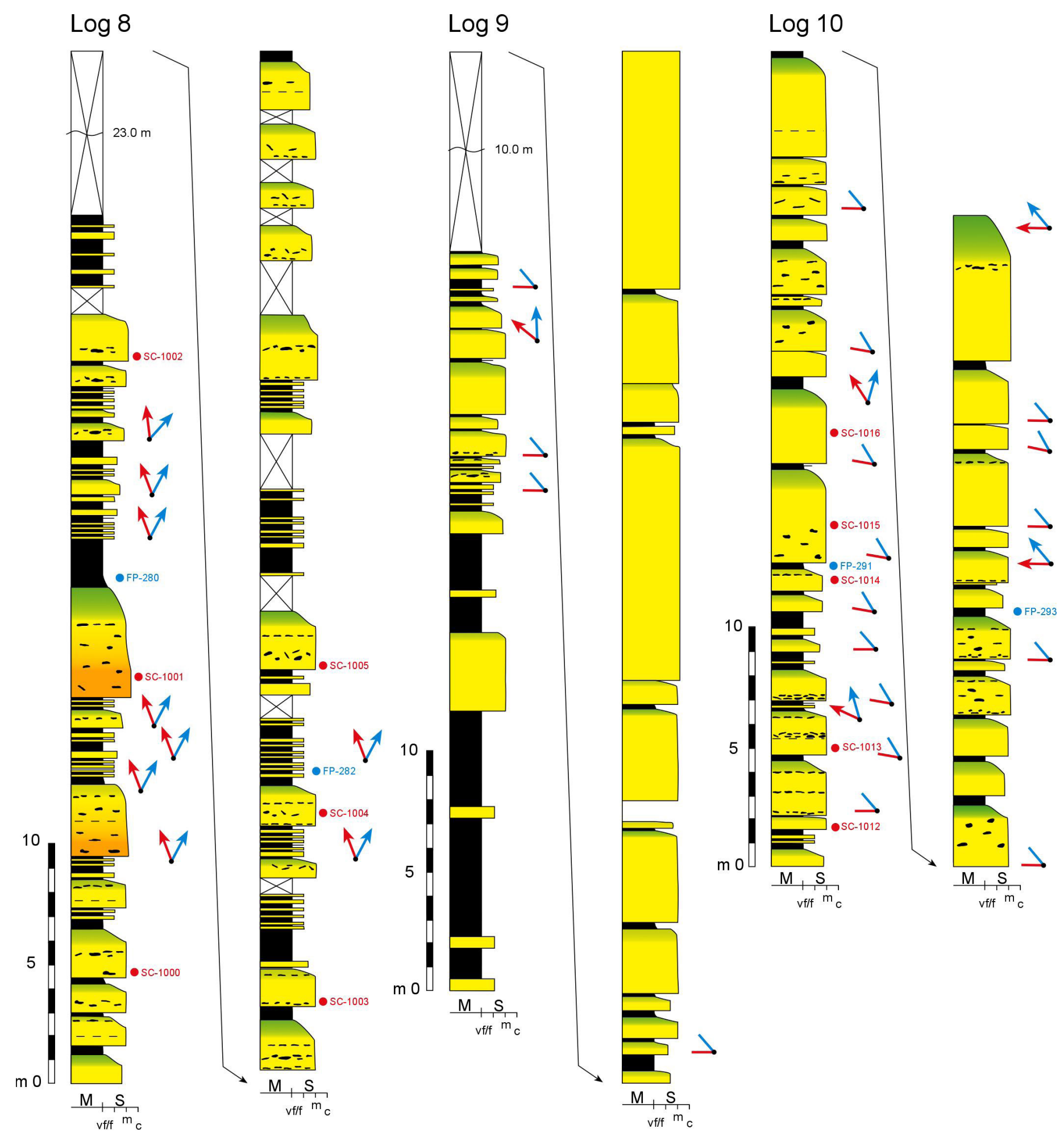

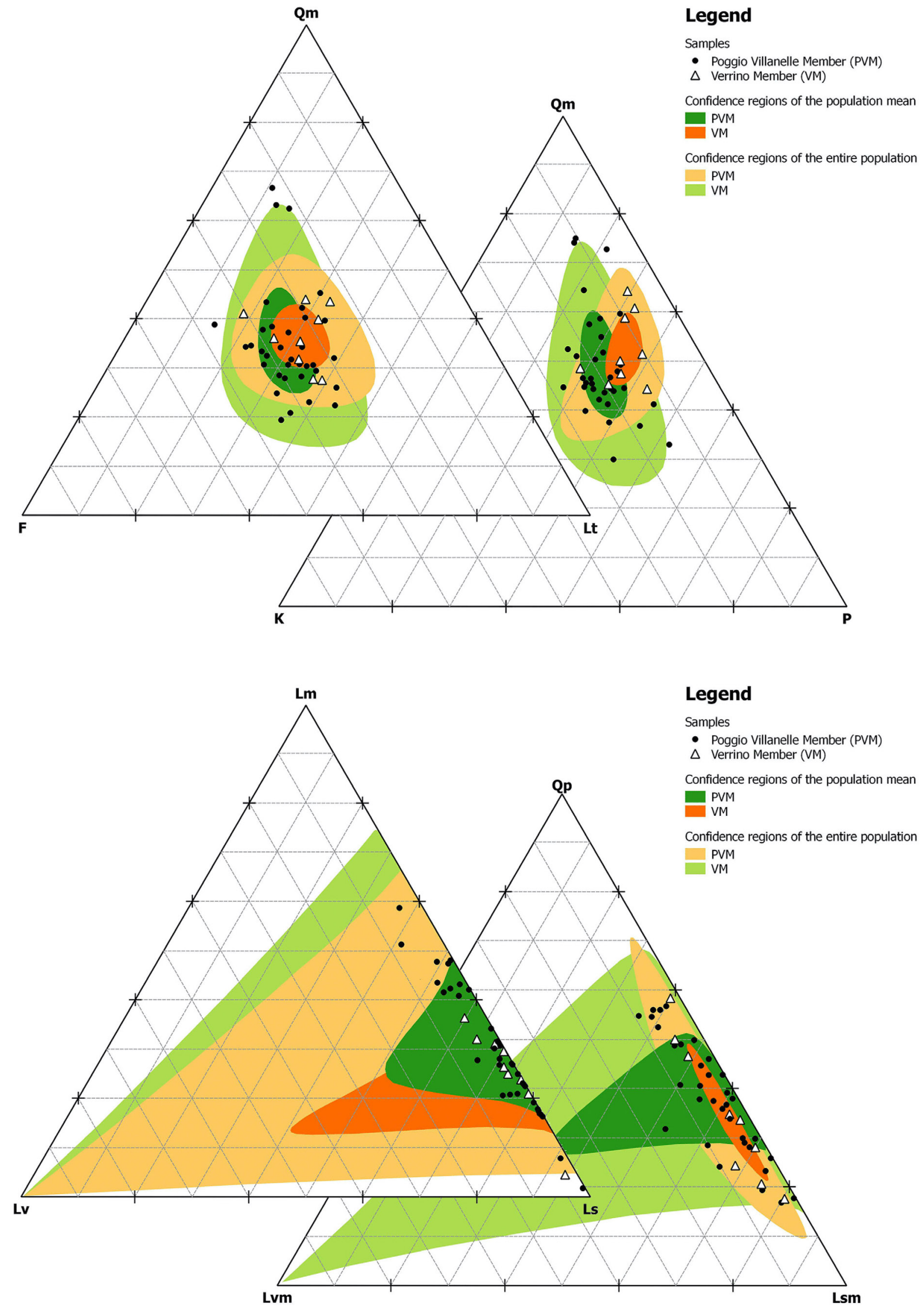

Fig. 9 - QmFLt, QmKP, QpLvmLsm, and LmLvLs ternary diagrams showing sandstone composition of the Agnone Flysch. Abbreviations: $\mathbf{Q m}$, monocrystalline quartz; $\mathbf{F}$, feldspar $(\mathrm{K}+\mathrm{P})$; $\mathbf{L t}$, aphanitic lithic fragments and fine-grained polycristalline quartz; K, k-feldspar; P, plagioclase; Qp , polycrystalline quartz; Lvm, volcanic and metavolcanic lithics; Lsm, sedimentary and metamorphic lithics; Lm, metamorphic lithics; Lv, volcanic lithics; Ls, sedimentary lithics. 


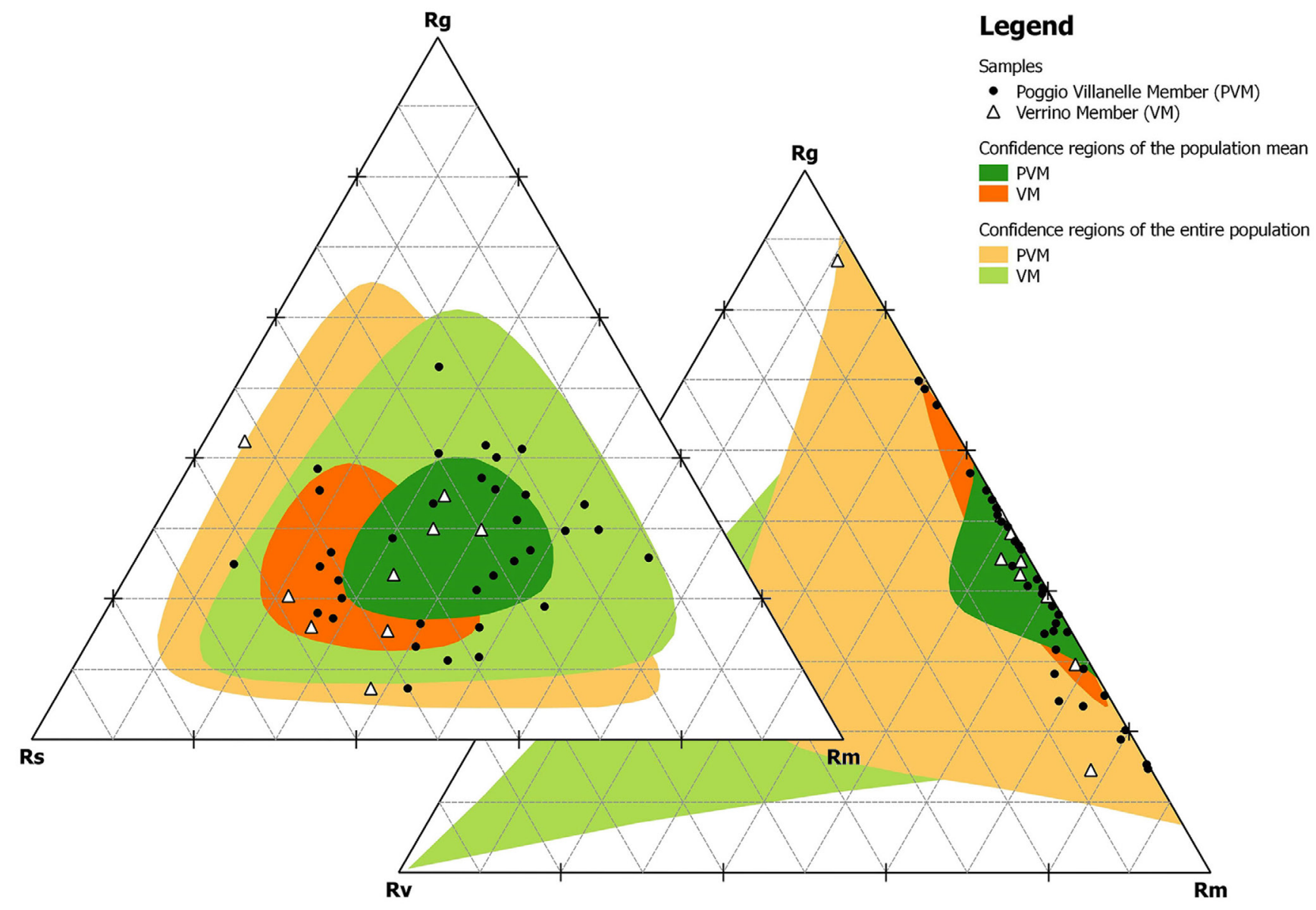

Fig. 10 - RgRmRs and RgRmRv ternary diagrams showing Agnone sandstone composition. Abbreviations: Rg, plutonic rock fragments; Rs, sedimentary lithic fragments; Rm, metamorphic rock/lithic fragments; Rv, volcanic rock/lithic fragments.

(Fig. 15). This type of beds generally occurs at the top of the FA1 and FA2 beds or form single beds passing upward and laterally to the laminated mudstone of Facies FA6. The Facies FA5 has some correspondence with the Tc-Td Bouma divisions and represents the product of tractionplus-fallout deposition from depletive and waning lowdensity turbidity currents (see MutTI (1992), PICKERING et alii (1995), Mutti et alii (1999) and Pickering \& Hiscott (2016).

The Facies FA6 is constituted by medium to thin massive to laminated mudstones beds, often intercalated by very thin silty beds (Fig. 16). The deposits of this facies suggest a deposition from a decelerating mud-rich low-density turbidity currents (Td-e Bouma divisions); coherent with this interpretation is the position of these beds occurring at the top of the facies sequences containing in the lower portion the facies FA1, or FA2 or FA3. The absence of bioturbation in these beds suggests a rapid settling of the mud due to its high concentration in the final phase of turbidity current deposition. Thin sand injections that originate from the underlying or overlying sandy layers are locally present (Fig. 16). Characters of this facies are similar to the muddy portion of the Facies F9 of Mutтi (1992), Mutтi et alii (1999), and to the Facies E1.1 of Pickering et alii (1995), and Pickering \& Hiscott (2016). The Facies FA6 occurs as turbidite mud cap in the lobe zone from proximal to distal sectors, although when it shows intercalations of silty layers it could be better interpreted as deposited in the inter-lobe packages (Mutтi, 1977). As recently discussed by Mutтi (2019), the thin-bedded and fine-grained turbidites of the Facies FA6 remain a problematic deposit whose sedimentary features can be also interpreted as the product of processes related to the proximity of delta systems developed in tectonicallyactive basins. MutTI (2019) suggests, in fact, that on the basis of more recent experimental and field monitoring of modern deltas studies (see PARson et alii, 2001; Mulder et alii, 2003; HIzZET et alii, 2018 and references therein), many of these thin-bedded and fine-grained turbidites, named by the Author plumites, could be generated from hypopycnal plumes and dilute hyperpycnal flows (see also MUTтI et alii, 2003; for more details on plumites facies description and interpretation see MuтTI, 2019). Such considerations have also been developed during the field observations of the Agnone turbidites, so it is not ruled out that Facies FA6 can be the result either distal sedimentation of decelerating dilute turbidite currents or the product of deposition of hypopycnal and dilute hyperpycnal flows (plumites, sensu MutTI, 2019). Due to limited exposure of the intervals of Facies FA6, it is not possible to discriminate with certainty whether this facies is an inter-lobe facies or a plumite, although paleocurrent data and the paleogeography reconstruction of the investigated area seem to suggest that most of the FA6 beds could be interpreted as plumites. 

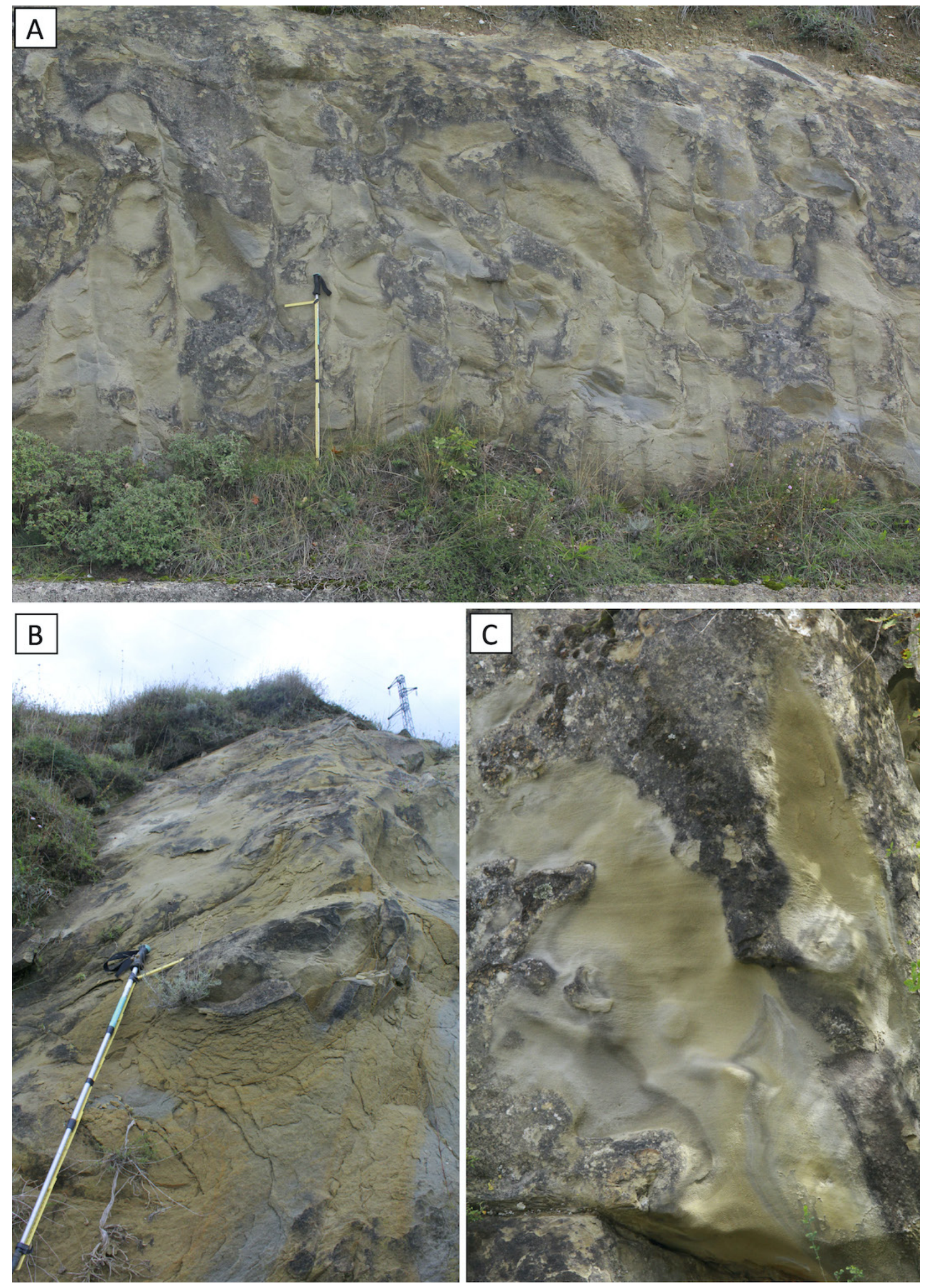

Fig. 11 - A) Typical aspect of the massive FA1 facies; B) top of FA1 bed showing the presence of bedforms (current ripples) induced by the overlying turbulent flow; C) Facies FA2 showing undulated lamination and water escape structure. 

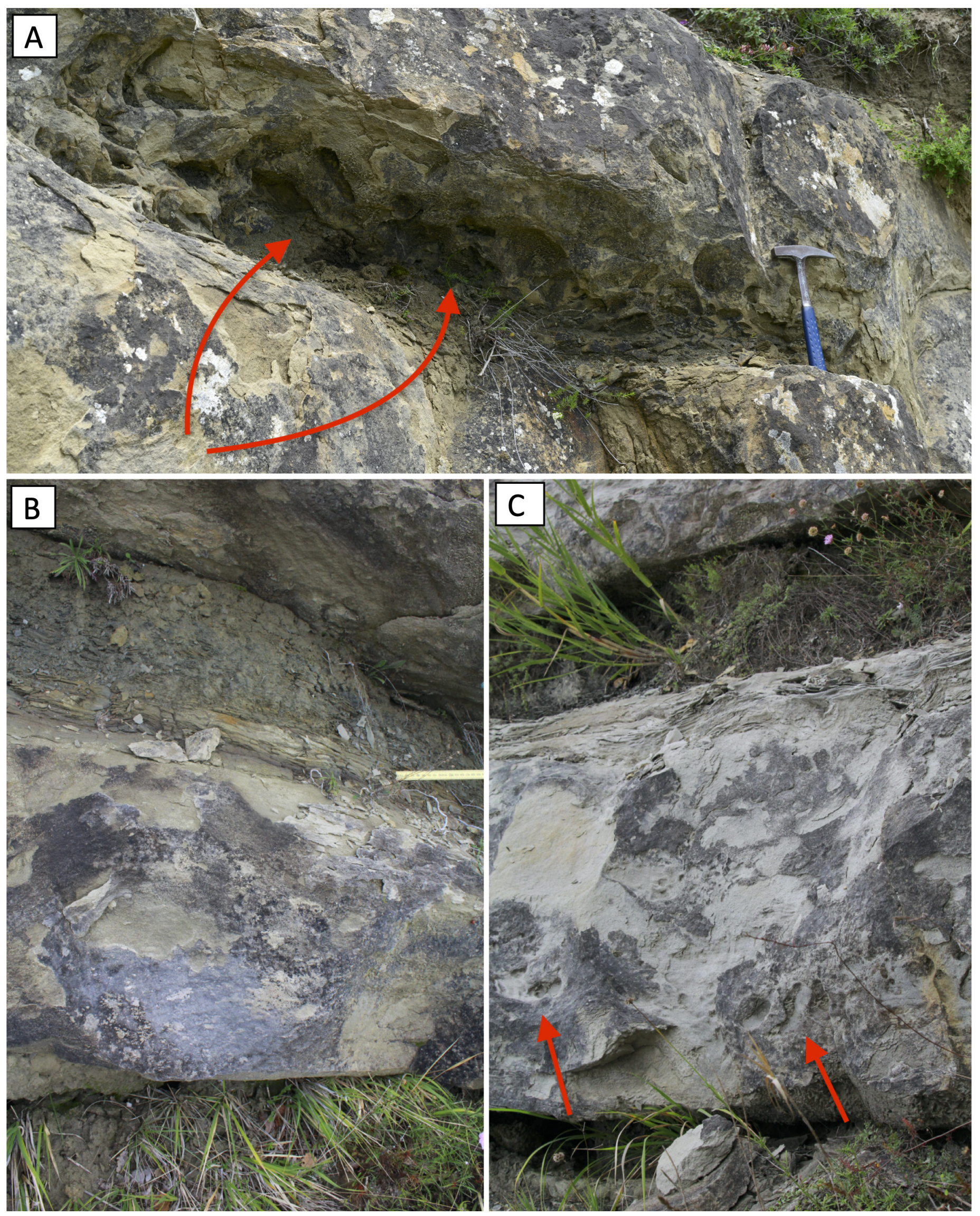

Fig. 12 - The Facies FA3 may contain mudstone clasts at different height within the beds or can be completely free. A) Concentration of mudstone clasts at the base of massive deposits; B) FA3 bed free of mudstone clasts; C) Mudstone clasts positioned at different heights in FA3 bed (bed is $1.20 \mathrm{~m}$ thick). 


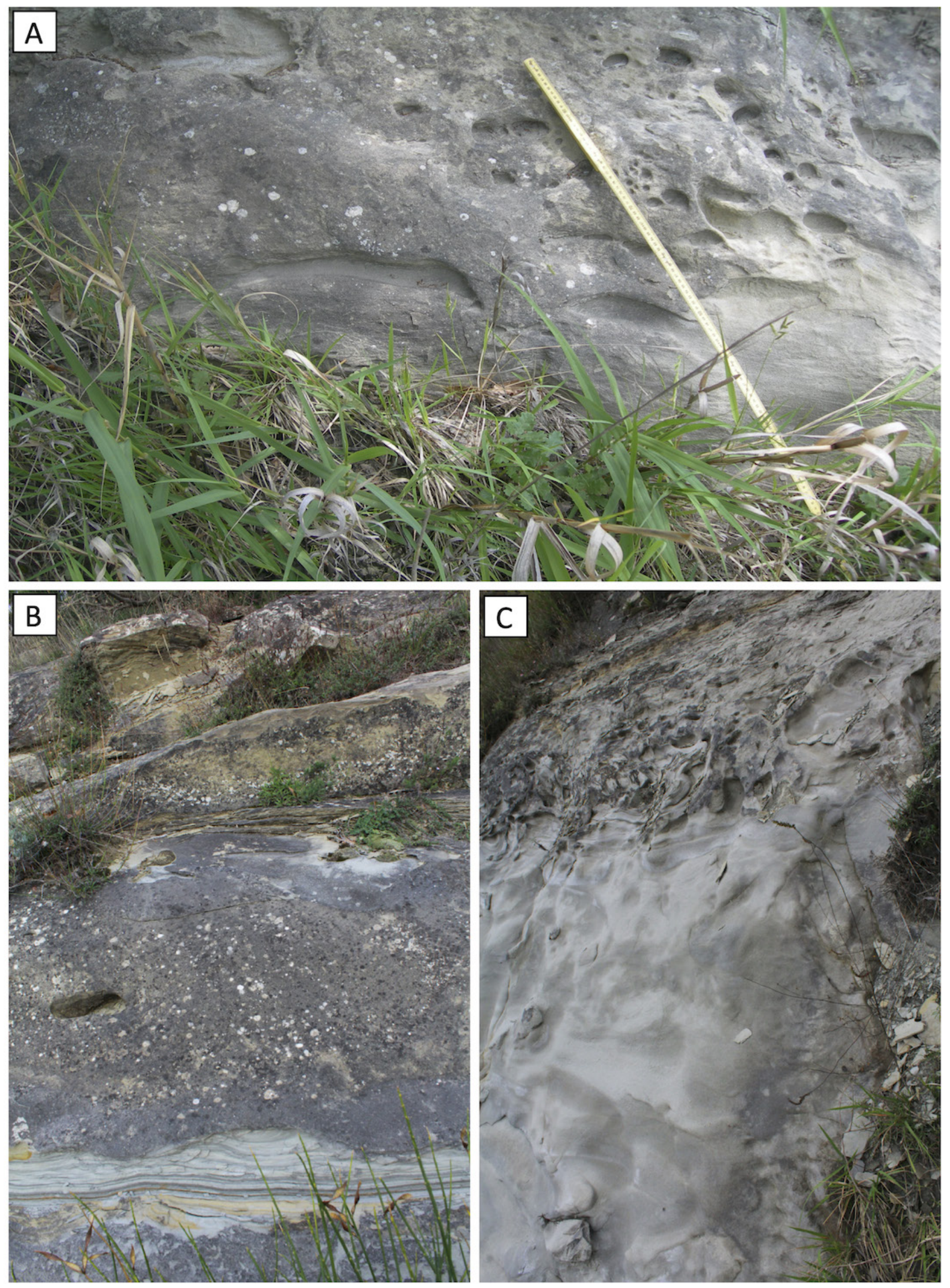

Fig. 13 - Other examples of facies FA3 with mudstone clasts concentrated at the base (A), isolated (B) or positioned at the top (C) of beds. The beds in B and C are $3 \mathrm{~m}$ thick respectively. 


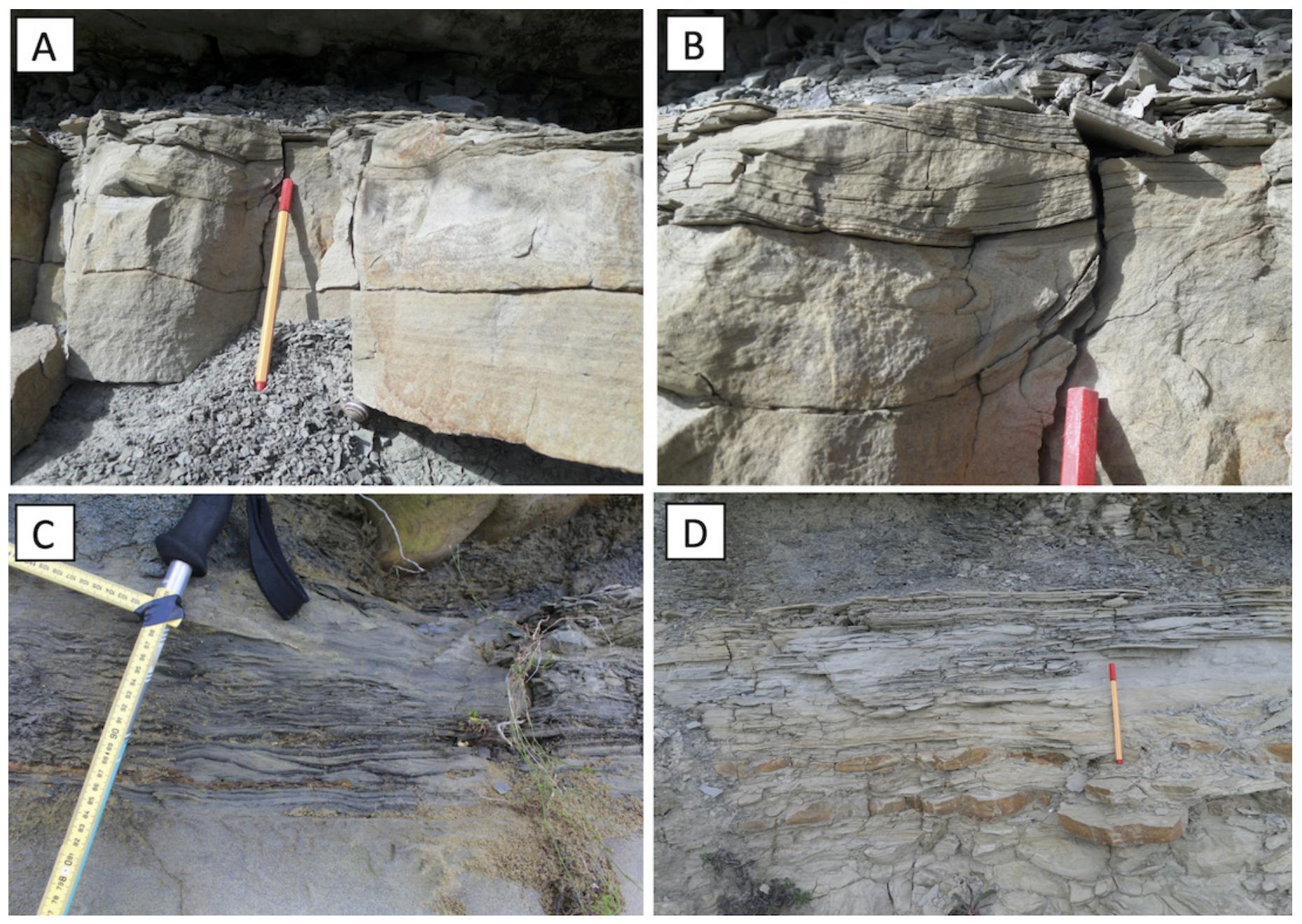

Fig. 14 - A to D) Examples of facies FA4 characterized by massive to crude-laminated sandstones in the lower part, passing upward to low-angle wavy laminae (hummocky-like structures) interpreted as related to rebound and reflection processes.

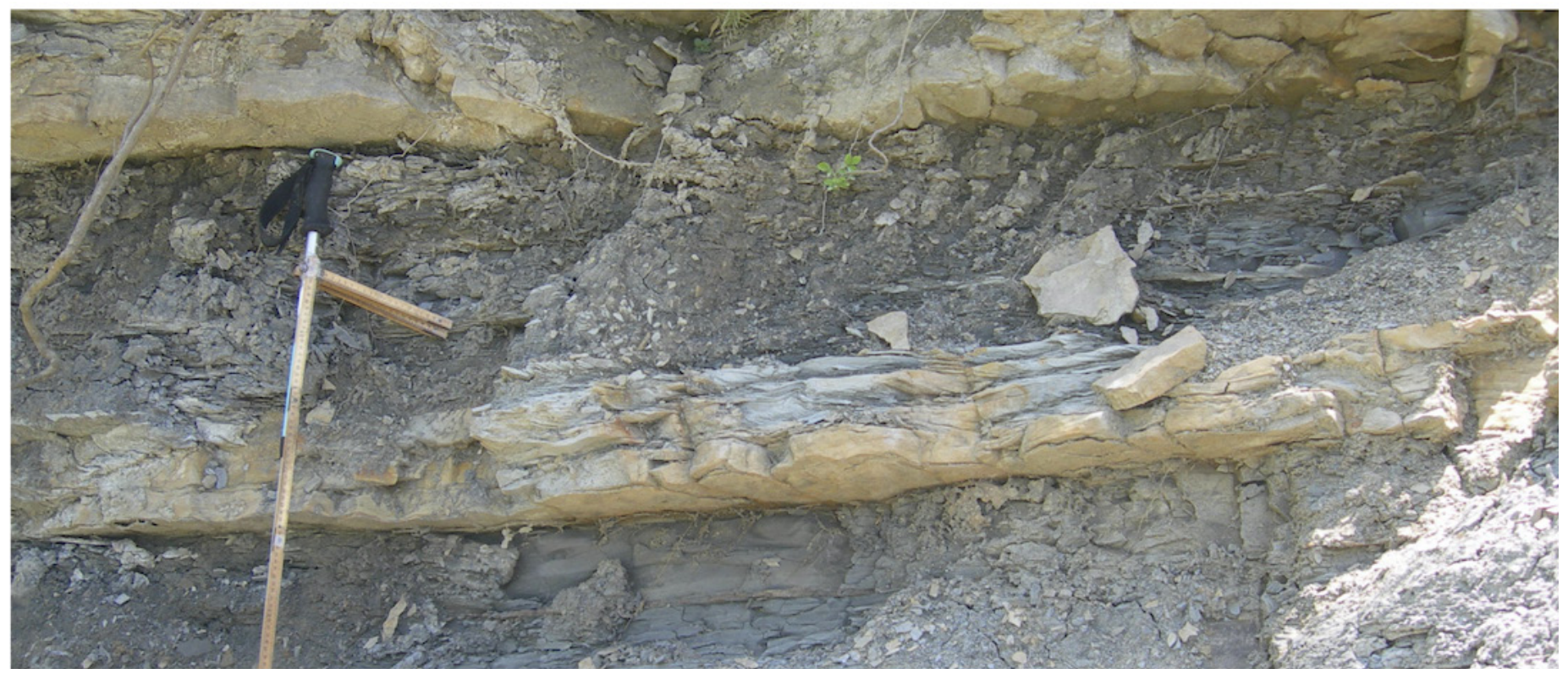

Fig. 15 - Facies FA5: bedset with climbing ripple cross lamination. 

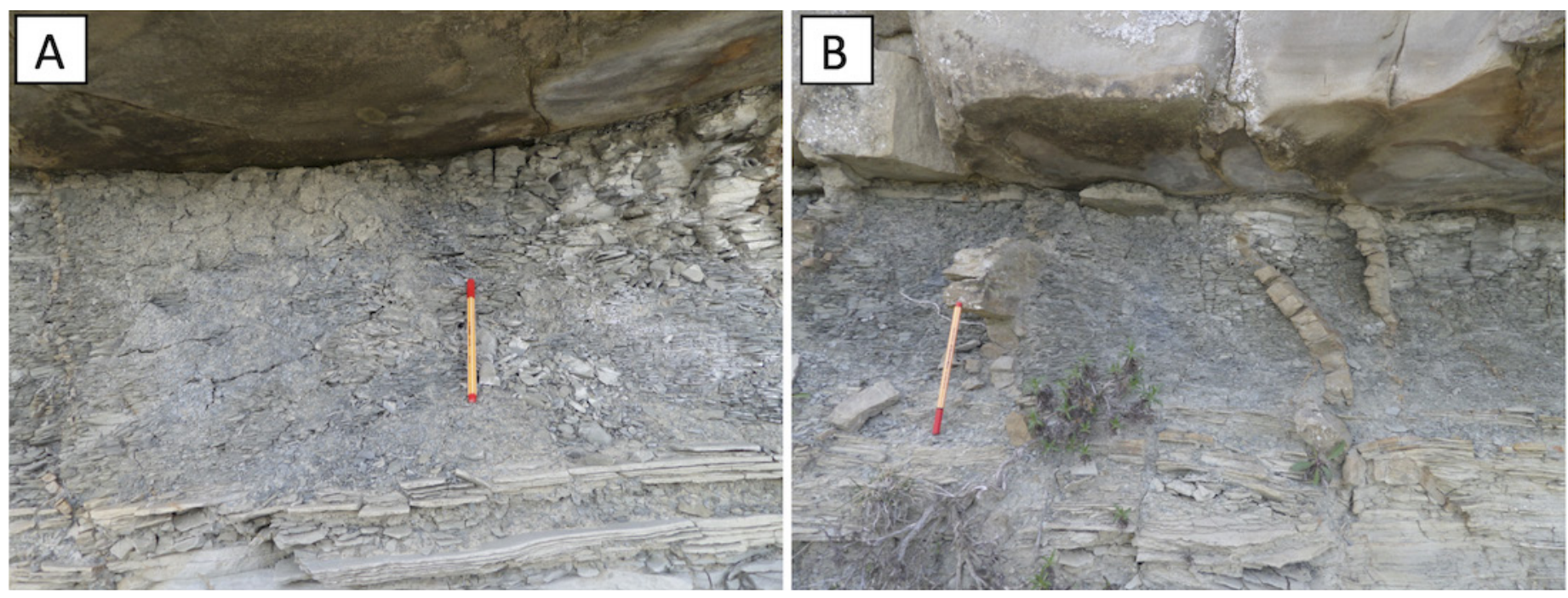

Fig. 16 - General aspect of the massive to laminated mudstone related to the facies FA6. Note in B the sand injection derived by the underlying and overlying sandstone beds.

The Facies FA7 is certainly the more complex facies being constituted by tripartite beds generally composed of 1) a lower ungraded to crudely graded medium-fine sandstone (30-100 $\mathrm{cm}$ thick), passing upward to 2) an intermediate muddy sandstone unit $(30-40 \mathrm{~cm}$ thick) with mud clasts and woody fragments and finally to 3) an upper fine and very fine-grained cross-laminated sandstone unit $(10-15 \mathrm{~cm}$ thick) that in some cases is lacking (Fig. 17). The unit 2 is poorly sorted and shows an internal deformation produced by liquefaction structures. Based on the reconstruction of the basin geometry in the investigated area (see after), this facies is here interpreted to form through the deceleration and transformations of the turbidity currents induced by submarine topography and in particular when the flows impact against the slopes of the basin and also the depositional reliefs (i.e., against the lobes). This process would produce a local hydraulic jump (see also Postma et alii, 2009), which would favor erosion of the cohesive mud where zones of lateral and vertical constriction occur, the mixing with the sand transported by the current, and the successive deposition of the bed due to the rapid deceleration forced by flow expansion. Such type of beds have been described in the literature since the 60's of the last century (see Ricci LuccHI, 1965; MarschalKo, 1970; Van Vliet, 1978; Mutti et alii, 1978; Ricci Lucchi \& VAlmori, 1980, slurry beds; Mutti \& NiLSEN, 1981). More recently many papers have discussed the processes responsible for the formation of these beds (see Lowe \& Guy, 2000; Haughton et alii, 2009; Sylvester \& Lowe, 2004; Talling et alii, 2004; Amy \& Talling, 2006; BaAs et alii, 2011; Hodgson, 2009; Sumner et alii, 2009; Muzzi Magalhaes \& Tinterri, 2010; Patacci et alii, 2014; MARINI et alii, 2011, 2015; Southern et alii, 2015; TINTERRI \& Tagliaferri, 2015; Fonnesu et alii, 2016, 2018; Kane et alii, 2017; Spycala et alii, 2017 with references therein), known in literature as "hybrid beds", although they are nothing more than the expression of local modifications of the rheology of turbidite currents interacting with the submarine topography. Most of these beds characterize the depositional lobe zone and the marginal sectors of the Agnone Basin where turbidite deposits onlapped onto the frontal and lateral slopes.

Overall, even if not treated in a statistical way, the observations of the measured sections allow us to say that the facies FA5 and FA6 are mainly developed in the Verrino member and constitute the upper portion of the beds with the facies FA1, FA2, FA3, and FA7. The latter, together with the FA4 facies, are instead mainly developed in the lower and middle portion of the Poggio Villanelle member, which records both the general progradational phase of the Agnone turbidite system and the greater confinement of the basin, probably connected to the eastward migration of the Apennine thrusts.

\section{SANDSTONE PETROGRAPHY}

Sandstones samples from Verrino and Poggio Villanelle members have a quartzofeldspathic composition. In spite of its quartzofeldspathic composition, two distinctive petrofacies can be recognized based on different lithic fragments proportions (Figs. 9, 10 and 18). Sandstones, in general, are characterized by phaneritic (single crystal $>0.0625 \mathrm{~mm}$ ) detritus with abundant quartz (single crystals and polycrystalline quartz with and without tectonic fabric; Fig. 18B), feldspar (plagioclase greater than K-feldspar), and micas derived from plutonic rocks (Fig. 18A), schist and gneiss rock/lithic fragments. The aphanitic (single crystal $<0.0625 \mathrm{~mm}$ ) lithics fragments include sedimentary and metamorphic fragments. Lithic fragments include both non-carbonate extrabasinal (NCE; ZUFFA, 1980), and extrabasinal carbonate fragments (CE; ZuFfa, 1980). Metamorphic fragments consist of common phyllite and fine-grained schist (Figs. 18C and 18D). The most common grains are the fine-grained schists. Minor ophiolitic lithic fragments include serpentinite and serpentine-schist (Figs. 18E and 18F). Dense minerals include apatite, epidote, garnet, rutile, tourmaline and zircon. The main interstitial component is sparitic and microsparitic carbonate cement with patchy calcite and pore-filling texture. The interstitial component also 

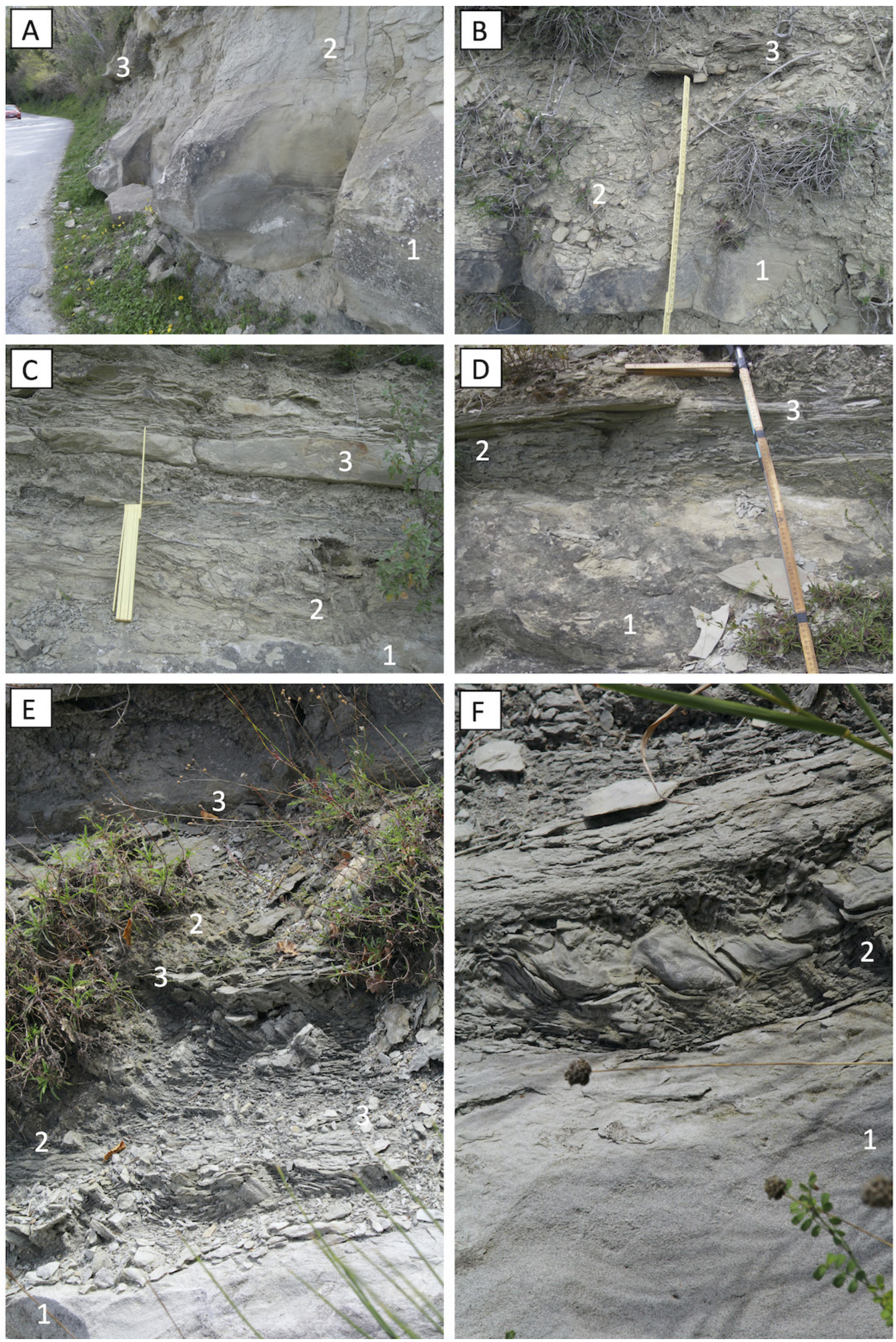

Fig. 17 - Example of FA7 beds showing the tripartite subdivisions with a 1) a lower ungraded to crudely graded medium-fine sandstone; 2) an intermediate muddy sandstone unit with mudstone clasts; 3 ) an upper fine and very fine-grained cross-laminated sandstone unit that in some cases is lacking. 

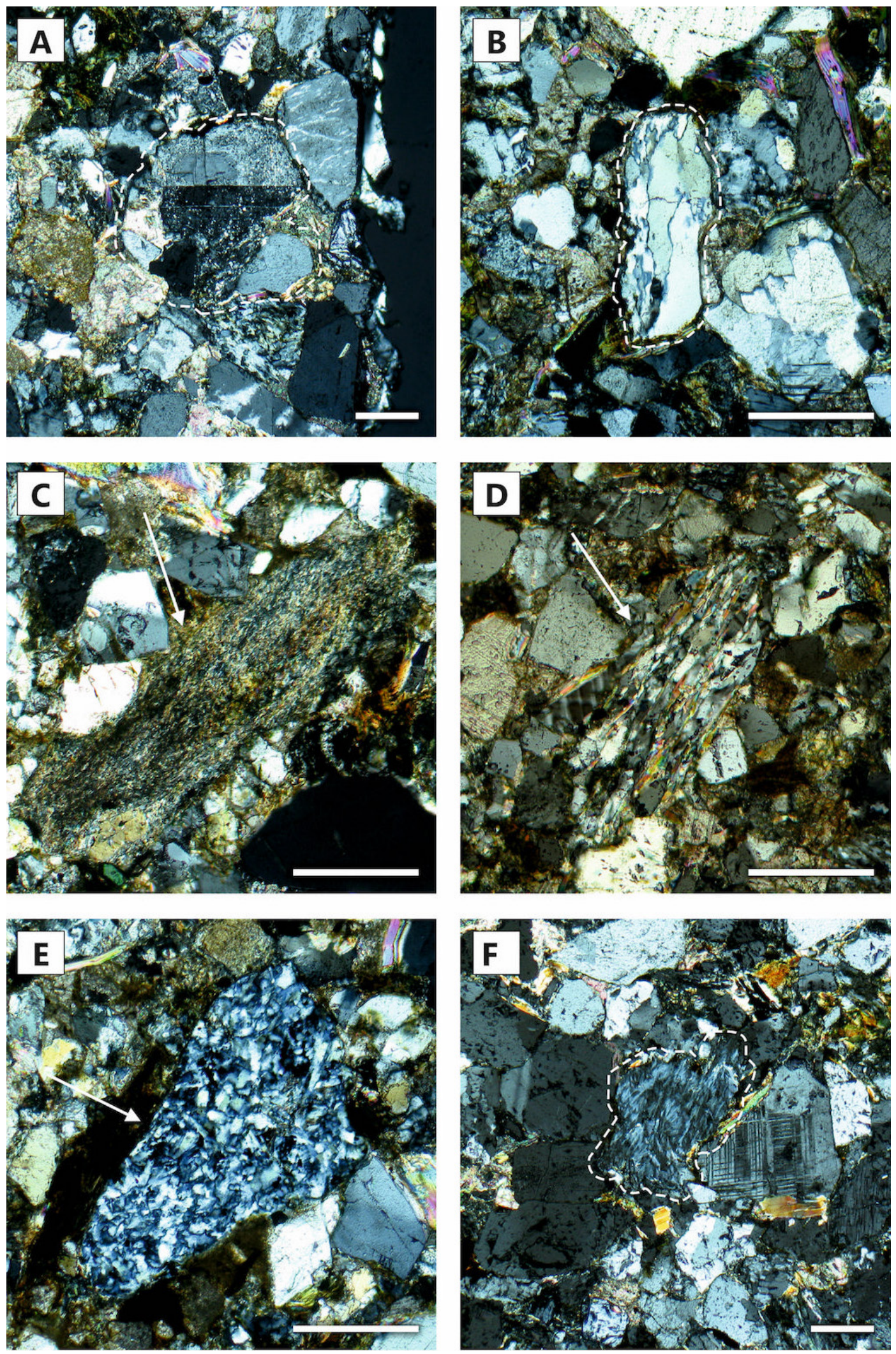

Fig. 18 - Thin sections showing photomicrographs of diagnostic grains. A) Plutonic rock fragment $(\mathrm{Rg}$ in the compositional diagram of figure 10) highlighted by the white dashed lines); B Polycrystalline quartz with tectonic fabric (stretched metamorphic quartz (Op) highlighted by the white dashed lines; C) Sedimentary lithic fragment (Ls), white arrow; D) Fine-grained schist (Lm), white arrow; E) Massive serpentine lithic fragmen (Lv), white arrow; F) Schistose serpentine lithic fragment (Lm), highlighted by the white dashed lines. All white bars (scale) are $200 \mu \mathrm{m}$. All photos are under crossed polars.

includes common siliciclastic and minor carbonate matrix.

Textural analysis allows identification of two types of grain-contacts: lower member sandstones (VM) show few 'floating' grains or punctual contacts, whereas in the middle member (PVM), grains contacts are mainly long and tangential. The nature of the contacts between sandstone grains is indicative of a gradual increase of packing up-section. Packing is largely dependent on the sorting and shape: the VM sandstones are composed of well/moderately sorted and sub-angular/rounded grains with a loose packing texture; instead, poorly/ 
moderately sorted sediments and sub-angular/rounded grains of PVM have a much closer packing.

\section{Petrofacies}

Recalculed and next plotted point-count data from aphanitic lithic fragments (QpLvmLsm; LmLvLs, Fig. 9) and phaneritic rock fragments (RgRsRm; RgRvRm, Fig. 10) allow to discriminate two distinct detrital populations (petrofacies A1 and A2) that have a good correspondance with the VM and PVM members respectively, which record a change in source areas over time. Means and standard deviations for the parameters that define the two petrofacies are given in Tab. S3 (see supplementary material. The A1 petrofacies shows a quartzofeldspathic composition (mean values of $\mathrm{Qm}_{36} \mathrm{~F}_{33} \mathrm{Lt}_{31} ; \mathrm{P} / \mathrm{F}=0.72$ ). The VM aphanitic lithic fragments average composition shows $\mathrm{Qp}_{35} \mathrm{Lvm}_{4} \mathrm{Lsm}_{61}$ and $\mathrm{Lm}_{26} \mathrm{Lv}_{2} \mathrm{Ls}_{72}$, with a clear abundance of sedimentary debris which is in part confirmed by the modal recalculation of the phaneritic rock fragments that shows an abundance of sedimentary rock fragments (mean $\mathrm{Rg}_{24} \mathrm{Rs}_{46} \mathrm{Rm}_{30}$ ), and metamorphic and plutonic debris $\left(\mathrm{Rg}_{45} \mathrm{Rv}_{2} \mathrm{Rm}_{53}\right)$. Also, the $\mathrm{A} 2$ petrofacies is characterized by quartzofeldspatic composition $\left(\mathrm{Qm}_{37} \mathrm{~F}_{37} \mathrm{Lt}_{26} ; \mathrm{P} / \mathrm{F}=0.66\right)$. The aphanitic lithic fragments show an abundance of sedimentary and metasedimentary lithic fragments $\left(\mathrm{Qp}_{43} \mathrm{Lvm}_{4} \mathrm{Lsm}_{53}\right.$ and $\left.\mathrm{Lm}_{43} \mathrm{Lv}_{2} \mathrm{Ls}_{56}\right)$ (Fig. 9); phaneritic rock fragments show a prevalence of metamorphic fragments over sedimentary, volcanic and plutonic fragments $\mathrm{Rg}_{26} \mathrm{Rs}_{29} \mathrm{Rm}_{45}$ and $\mathrm{Rg}_{38} \mathrm{Rv}_{1} \mathrm{Rm}_{61}$ (Fig. 10).

\section{MUdROCK MINERALOGY}

\section{Bulk rock composition}

Mudrock samples from Poggio Villanelle member are mainly composed of phyllosilicates that prevail over the quartz and felspar, whereas the Verrino member samples show more carbonates (calcite and dolomite). The XRD patterns and semiquantitative data of the whole rock and clay fraction are shown in Fig. 19 and Tab. 3, respectively. The average value of the phyllosilicates both in the VM and PVM mudrock samples are quite similar, whereas of the non-phyllosilicate phases that show different percentages in the studied samples. In detail, the phyllosilicates show very similar amounts in the two members, ranging from $20-30 \%$ to $55-60 \%$, and are composed of mixed-layer phases, illite and micas, chlorite, with minor amounts of kaolinite. The non-phyllosilicate phases, ranging from 40$45 \%$ to $70-75 \%$, are mainly composed of calcite, quartz, feldspars (K-feldspar and plagioclases) and dolomite and show a different trend in the two members. In particular, the mudrock samples of the VM show high amounts of calcite with values ranging from $5-10 \%$ to $55-60 \%$, and

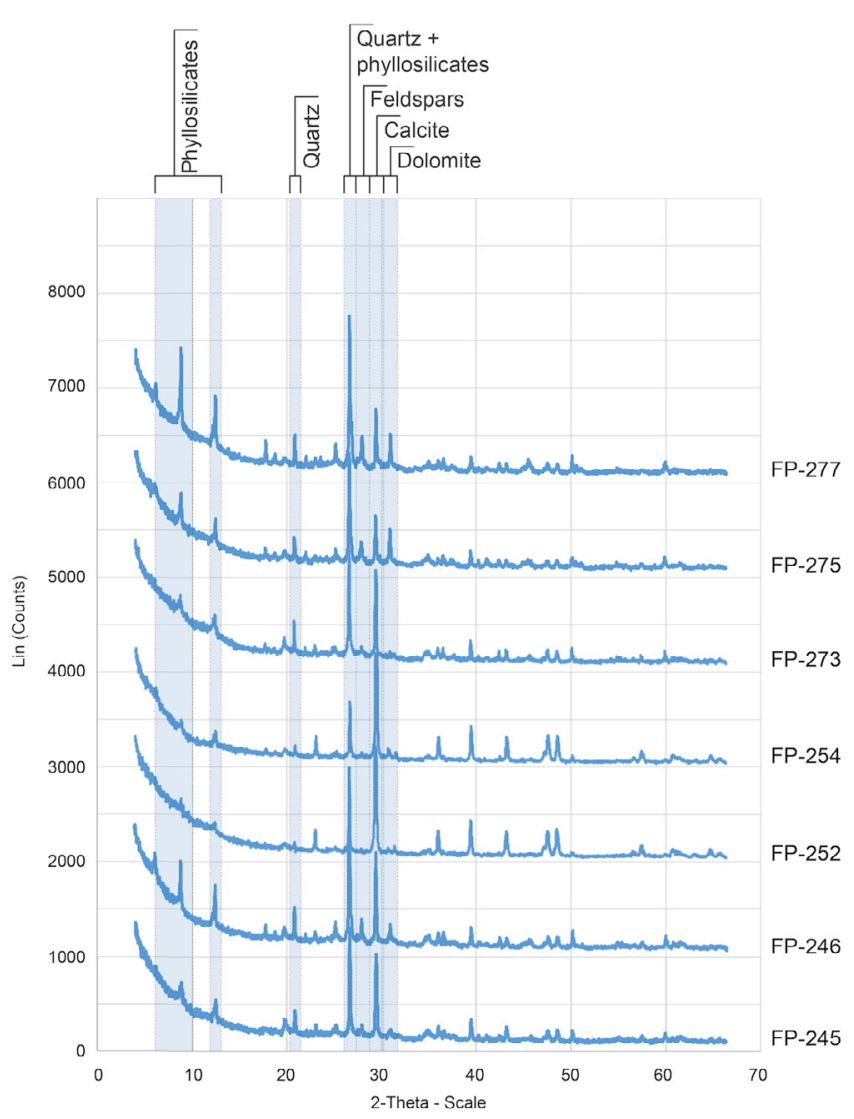

A

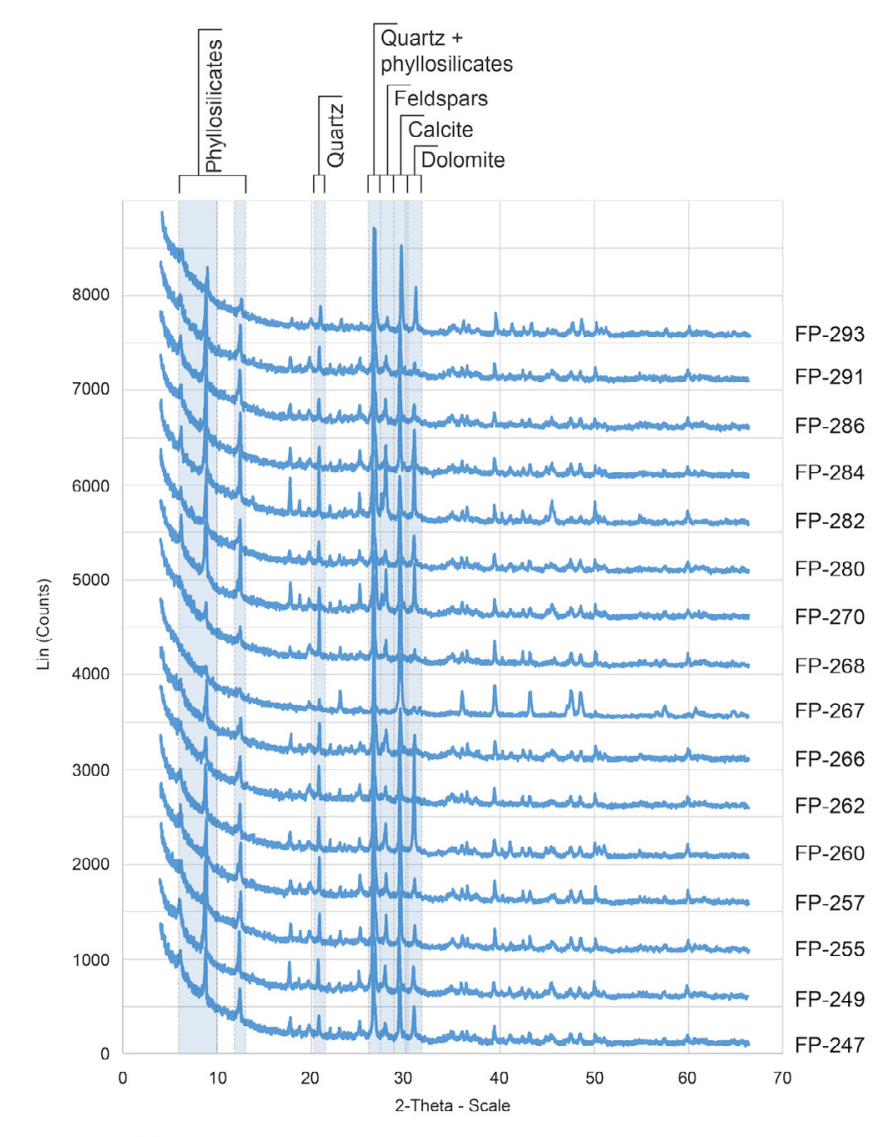

B

Fig. 19 - X-Ray Diffraction patterns of the studied mudrock samples. The mineralogical components are indicated in correspondence of the significant peaks. A) XRD patterns of the Verrino Member; B) XRD patterns of the Poggio Villanelle Member. 
TABLE 3

Semiquantitative abundances of mineralogical components observed in mudrock samples. The increasing intensity is indicated by the "+" symbol: mineralogical concentrations range from absent $(-)$, low $(+)$, normal $(++)$, high $(+++)$ to very high $(++++)$, in particular: $-=0 \% ;+=1 \leq \mathrm{x} \leq 5 ;++=5<\mathrm{x} \leq 20 ;+++=20<\mathrm{x} \leq 40 ;++++=40<\mathrm{x} \leq 60 ; \mathrm{Dol}=$ dolomite; Calc = calcite; $\mathrm{Pl}=$ plagioclase; $\mathrm{Kfs}=$ potassium feldspar; $\mathrm{Qz}=$ quartz; $\Sigma \mathrm{Phyl}=$ phyllosilicates $(=$ Mixed-layer phases + Micas and illite $+\mathrm{Kln}+\mathrm{Chl}) ; \mathrm{Chl}=$ chlorite; Kln = kaolinite.

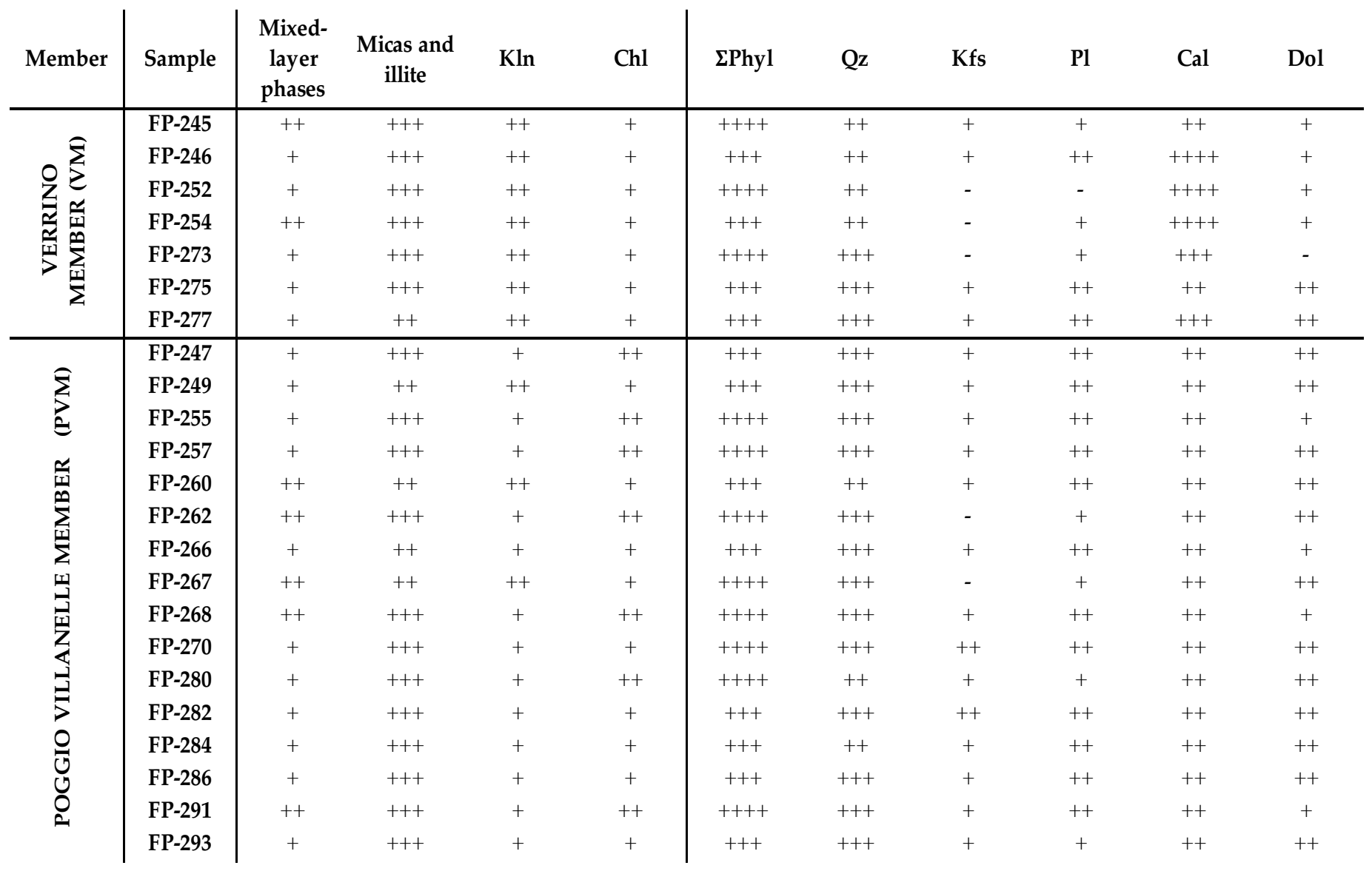

minor amounts of quartz, feldspars $(\mathrm{K}+\mathrm{P})$ and dolomite in a decreasing order of abundance. The samples of the PVM, show more abundance of quartz, ranging from $5-10 \%$ to $35-40 \%$, than calcite, with a mean value of $15 \%$, compared to the samples of the VM, and minor amounts of feldspar and dolomite as shown by the XRD patterns in figures 19A and 19B. The mudrock mineral abundances of both members retrieved by X-ray diffraction show a quite similar trend to the above-mentioned evolution of the sandstone petrofacies.

\section{Clay mineralogy}

Selected mudrock samples (three from VM and five from PVM) were also studied to characterize in detail the clay minerals, on the oriented specimens. XRD analyses of the air-dried specimens, glycolated and heated were carried out (Figs. 20A and 20B).

The $<2 \mu \mathrm{m}$ grain-size fraction (Tab. 4) is mainly composed of I/S mixed layers, with a percentage ranging from $40 \%$ to $60 \%$. Illite content has a similar percentage on average (15-20\%) in both members and these contents are witnessed by X-ray diffraction patterns of the ethylene-glycol solvated specimens that show particularly broad reflections between $8.5-9.5^{\circ} 2 \theta$. Chlorite and kaolinite contents usually are low, with a percentage ranging from $5 \%$ to $15 \%$ (see Tab. 4).

Decomposition of X-ray diffraction patterns of the glycolated oriented slides was performed: as regard the illite percentage in I/S and the stacking order $\mathrm{R}$, patterns of all eight samples show broad reflections at about $5^{\circ} 2 \theta$ (I/S R0) and weak peaks at about $9.4^{\circ} 2 \theta$ (I/S R1) and $10^{\circ} 2 \theta(\mathrm{I} / \mathrm{S} \mathrm{R} 0)$. The percentage of illite (\%I) and stacking order $(\mathrm{R})$ of the I/S mixed layers was determined on the spectrum of the glycolated oriented slides using the Moore \& ReYnolds (1997) method. XRD pattern of the glycolated specimens mainly show the occurrence of the I/S R0 and I/S R1, with illite percentage ranging from $40 \%$ to $70 \%$, that imply an early diagenetic condition for the Agnone Flysch (see also MERriam \& FrEY, 1999; Aldega et alii, 2007; Bigi et alii, 2009). The occurrence of randomly interstratified illite/smectite and ordered I/S mixed layers suggest a complex history for the studied successions (e.g., CAVAlCANTE et alii, 2007; CoRrado et alii, 2010). In particular, the presence of ordered I/S mixed 
TABLE 4

Mineralogical composition of the mudrock <2 $\mu \mathrm{m}$ fraction (semiquantitative abundances). Kln = kaolinite; Chl = chlorite; Ilt = illite; I/S = illite/smectite mixed layers; $\mathrm{R}=$ Reichweite (stacking order of the illite/smectite mixed layer);

+ , increasing intensity where: $+=x \leq 10,++=10<x \leq 20,+++=x>20$.

\begin{tabular}{|c|c|c|c|c|c|c|c|}
\hline \multirow{2}{*}{ Formation } & \multirow{2}{*}{ Sample } & \multirow{2}{*}{$K \ln$} & \multirow{2}{*}{ Chl } & \multirow{2}{*}{ Ilt } & \multirow{2}{*}{$\begin{array}{c}\text { Mixed layer } \\
\text { phases (I/S) }\end{array}$} & \multicolumn{2}{|c|}{$\mathrm{I} / \mathrm{S}$ feature } \\
\hline & & & & & & Reichweite & $\%$ illite \\
\hline \multirow{3}{*}{$\begin{array}{l}\text { VERRINO } \\
\text { (VM) }\end{array}$} & FP-246 & ++ & + & $\overline{++}$ & +++ & R0 and R1 & $40-50$ and $60-70$ \\
\hline & FP-252 & ++ & + & ++ & +++ & $\mathrm{R} 0$ and R1 & $40-50$ and $60-70$ \\
\hline & FP-254 & ++ & + & ++ & +++ & $\mathrm{R} 0$ and R1 & $40-50$ and $60-70$ \\
\hline \multirow{5}{*}{$\begin{array}{l}\text { POGGIO } \\
\text { VILLANELLE } \\
\text { (PVM) }\end{array}$} & FP-249 & ++ & ++ & ++ & +++ & R0 and R1 & $40-50$ and $60-70$ \\
\hline & FP-257 & + & ++ & ++ & +++ & $\mathrm{R} 0$ and R1 & $40-50$ and $60-70$ \\
\hline & FP-260 & ++ & ++ & ++ & +++ & $\mathrm{R} 0$ and R1 & $40-50$ and $60-70$ \\
\hline & FP-262 & + & ++ & ++ & +++ & $\mathrm{R} 0$ and $\mathrm{R} 1$ & $40-50$ and $60-70$ \\
\hline & FP-291 & + & ++ & ++ & +++ & $\mathrm{R} 0$ and $\mathrm{R} 1$ & $40-50$ and $60-70$ \\
\hline
\end{tabular}

layers could be also related to a provenance of inherited minerals from the neighboring area at the time of deposition, as is the case of fore-arc and foreland basins (e.g., Merriman, 2005; Cavalcante et alii, 2007).

\section{DISCUSSION}

\section{COMPOSITIONAL CHARACTERS}

\section{Provenance of detritus}

Two petrofacies (VM and PVM) are identified by visual inspection of the sandstones distribution (see ternary plots in Figs. 9 and 10) and main compositional data are reported in Tab. S3 (see supplementary material).

An upsection increase of feldspar was observed by comparing the mean values of both sandstone members, in particular the QmFLt and QmKP relative proportions (Fig. 9). This evidence suggests a change to increased metamorphic and plutonic contribution, which is also reflected in the $\mathrm{Lm}$ and $\mathrm{Rm}$ content (in LmLvLs and RgRvRm, ternary diagrams respectively) and in the $\mathrm{Rg}$ and Rm (see RgRsRm ternary diagram), that increased up-section too. A strong support to the metamorphic detrital contribution during PVM deposition is confirmed by plagioclase/feldspar ratio that decreases from lower member with 0.72 value to 0.66 in the overlying member.
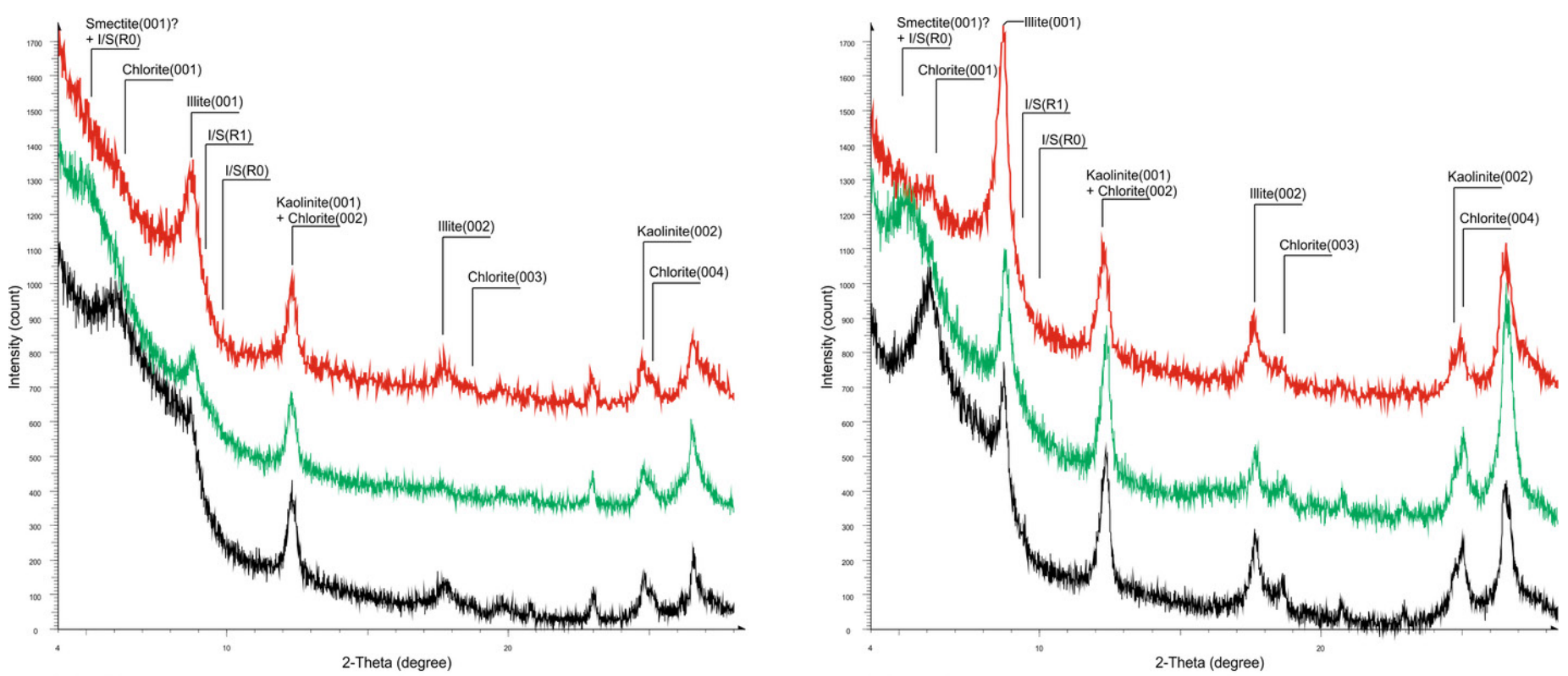

(A) - FP252

(B) - FP249

Fig. 20 - XRD pattern of the $<2 \mu \mathrm{m}$ fraction of air-dried (black line), glycolated (green line) and heated (red line) specimens. The most representative patterns of the Verrino Member (A) and the Poggio Villanelle Member (B) are shown. 
Furthermore, an upward decreasing trend of lithic rocks fragments (Rs) and especially sedimentary lithic component (Ls), was observed (see LmLvLs and RgRsRm in Tab. S3; see supplementary material).

The mudrock mineral abundances (non-phyllosilicate phases) of each member retrieved by X-ray diffraction show a quite similar trend to the above-mentioned evolution of the sandstone petrofacies. In fact, there is an upward increasing of feldspar and a similar pattern about the $\mathrm{P} / \mathrm{F}$ ratio ( 0.74 for $\mathrm{VM}$ and 0.69 for PVM). Moreover, the high sedimentary content recorded by VM sandstone samples was confirmed by the greater carbonate content in the associated mudrock samples.

As previously highlighted, the analysis of clay minerals suggests conditions of early diagenesis for the Agnone Flysch. This is consistent with the results occurring in Di BuccI et alii (1996) and CoRrado et alii (1998, 2010) who sampled the VM of the Agnone Flysch and the underlying Varicoloured Clays. These Authors investigated these litostratigraphic units using optical indicators of organic matter maturity (vitrinite reflectance and thermal alteration index) and clay mineralogy arriving at the following results: 1) the VM turbidite deposits show low levels of organic maturity so indicating early mature hydrocarbon generation that suggests an early diagenesis for these deposits; 2) the clay minerals of the Varicoloured Clays are essentially constituted by highly smectitic interstratified illite/smectite and are similar to the clay composition of the VM and PVM. These data were used to calibrate burial and thermal evolution of this investigated sector. The results indicate that these lithostratigraphic units were never overthrust at least before the Pliocene, so suggesting a consistency with our data indicating an early diagenesis for the Agnone Flysch and a detritical origin of the clay minerals. These considerations, based on the sandstone petrography and the mudrock mineralogy, provide useful information about the evolutionary history of the Agnone Flysch.

Clastic contributions from different sources were supposed by a) a calciclastic Apenninic source and, b) a terrigenous siliciclastic source mainly from metamorphic and magmatic sources, that should derive, according to our interpretation of the sandstone petrography and mudrock mineralogy data, from crystalline terranes occurring in the Tyrrhenian sector and from Calabrian Paleozoic rocks. In detail, the formation of VM could be linked to a period of strong tectonic activity, also recognized in a nearby areas to the west of the Agnone Basin (M. Massico ridge) and dated to late Tortonian and early Messinian time (SMERAGLia et alii, 2019), that should be related to rearrangement, accretion and eastward migration of the southern Apennines (BARONE et alii, 2006; CRITELLI, 2018). The abundance of crystalline debris in the PVM, should reflect a derivation from Tyrrhenian crystalline terranes (now partially disappeared) (e.g., DAL PIAZ et alii, 1983), and from unroofing of the Calabrian terranes (CRITELLI et alii, 2017). This last interpretation is confirmed by the coexistence of sub-angular feldspar debris and subangular quartz crystals in skeleton sandstones that are an evidence of fresh debris deriving from terranes affected by physical weathering first uplifted and then exposed to erosion (e.g., ScARCIGLIA et alii, 2007, 2016).

Because of the potential importance of the metamorphic detritus, a Ls-Lm1-Lm2 diagram (DoRsEY,
1988) has been used in which lithic fragments are divided into: i) sedimentary (Ls); ii) low-grade metamorphic (Lm1); and iii) medium-high-grade metamorphic (Lm2). This diagram shows a trend in lithic grains in sandstones that move from a high content of Ls (at the top of the triangular diagram) and proceeds downward showing an increase of Lm1 and mostly Lm2 (Fig. 21). This trend starts with $\mathrm{Ls}_{74} \mathrm{Lm} 1_{17} \mathrm{Lm} 2_{10}$ in VM and move to $\mathrm{Ls}_{56} \mathrm{Lm} 1_{21} \mathrm{Lm} 2_{22}$ in PVM, so suggesting a change in relative abundance of sedimentary and metamorphic lithic fragments through time and space.

\section{Paleocurrents}

Paleocurrents measurements have been treated separately as they represent a fundamental point, together with the compositional data, for the paleogeographic reconstruction of the Agnone Basin.

A total of 66 paleocurrents were measured in both the Verrino and Poggio Villanelle members along the logged sections, subdivided into flute and groove cast and ripples. A separate discussion must be made for the calcarenite beds that with different thicknesses are intercalated in the deposits of the Verrino and Poggio Villanelle members. For these beds, emplaced through sediment gravity flows, the paleocurrent data (CIVITELLI \& CORDA, 1988), suggested to the Authors their provenance from the western and north-western sectors of the basin, where the carbonate platforms of Matese, Simbruini and western Marsica were located.

In the sandstone beds, flute and groove casts indicate that the paleocurrents moved toward the western sectors, having a dispersion angle between $270^{\circ}$ and $320^{\circ}$. Similar indications are suggested by the ripples foreset laminae, although the dispersion angle is between $270^{\circ}$ and $360^{\circ}$.

Considering the present paleocurrents direction, it seems evident that the turbidite currents should come from the eastern sectors, from an area currently, and even in the past occupied by the Apulia carbonate platform. This is entirely in contrast to the compositional data which, on the contrary, suggest an origin of these sediments from a source area where magmatic, metamorphic and sedimentary rocks cropped out.

In order to reconcile the sandstone compositional data with those ones of the paleocurrents, we took into consideration the paleomagnetic analysis from the Upper Miocene sedimentary succession of the Molise area (SPERANZa et alii, 1998) and other paleomagnetic data reported in VITALE \& CIARCIA (2013). These paleomagnetic results suggest that the investigated area (sector of the Matese-Frosolone thrust sheets) underwent a counterclockwise rotation at least of $35^{\circ}$ after the Messinian time. On this basis, it is evident that the direction of the paleocurrents measured in the turbidite deposits of the Agnone Flysch, must be corrected in order to consider the post-Messinian tectonic movements and the partial reorientation of the flows due to the basin topography and the depositional reliefs themselves. By making these corrections, it follows that the turbidity currents which supplied the Agnone Basin came, essentially, from the southwestern and southern sector and moved towards the northern sectors, with a dispersion range between NNW and NNE. This interpretation is consistent with the compositional data suggesting a provenance of turbidite 


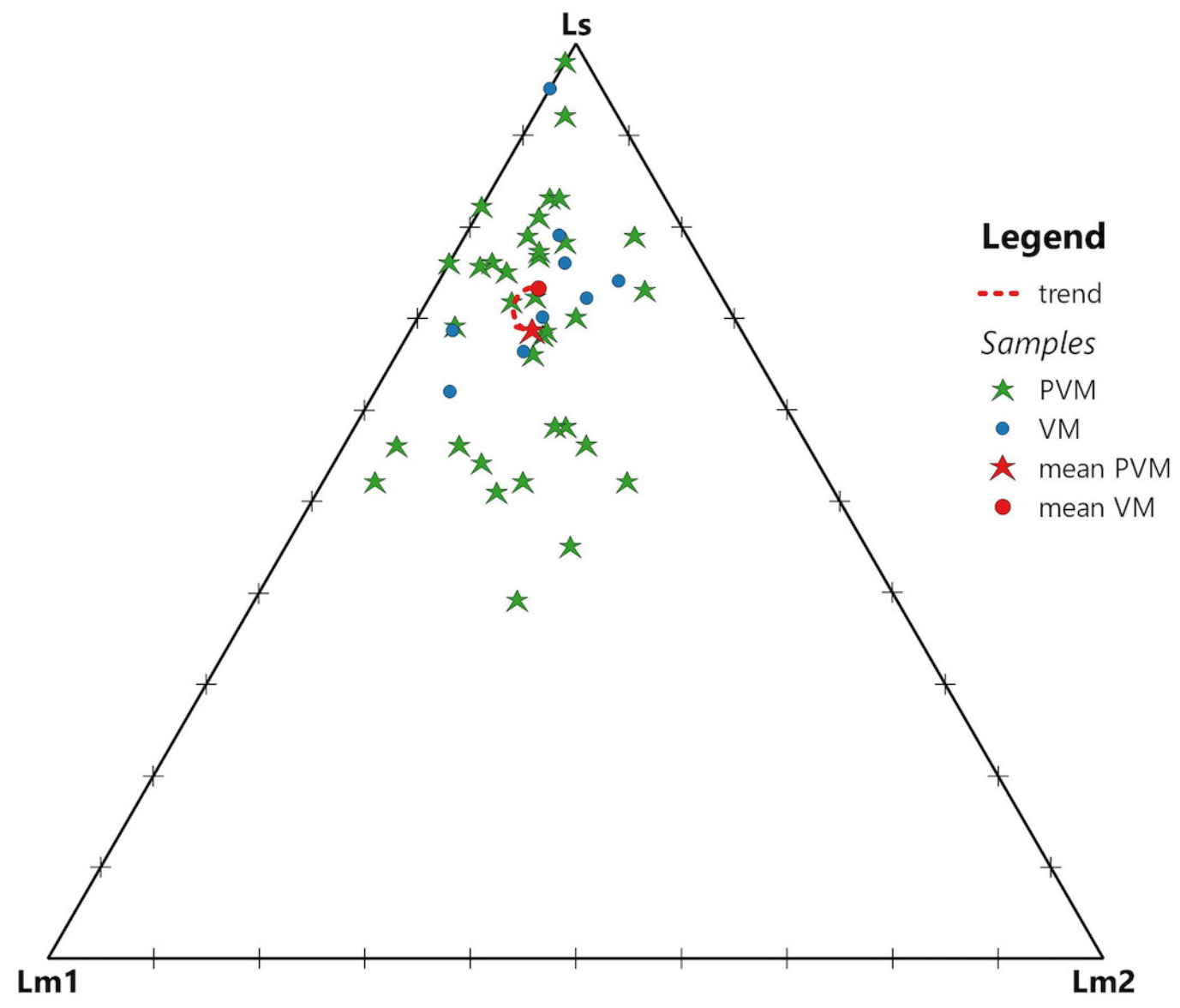

Fig. 21 - Unroofing trend in Ls-Lm1-Lm2 diagram of sedimentary and metamorphic complex of fold-thrust belt (see Tabs. 1, 2, and S3 (see supplementary material) for the significance of Ls-Lm1Lm2). flows from the southwestern and southern areas, where a mountain range with metamorphic and magmatic rocks stretched in the Tyrrhenian sector to the Calabrian Arc terranes.

Geometry of the Agnone Basin in the investigated area and TOPOGRAPHIC CONTROL ON FACIES PARTITIONING

The sedimentary characters of the facies described above together with paleocurrents, texture and composition of sandstone and mudstone beds, suggest a deposition of these sediments in the lobe depositional zone (for the lobes nomenclature we followed Mutтi et alii, 1999, PRÉlat et alii, 2009, and MARINI et alii, 2015, distinguishing proximal, distal and distal fringe subenvironments from the up- to downcurrent and lobe axis, off-axis and lateral fringe subenvironments perpendicularly to flow direction). Coherent with this interpretation are the sharp bases and the lenticular and tabular laterally continuous geometry of the sandstone bodies (see detailed correlation panels of figures 22 and 23) and their hierarchy, which would record at large scale and on the bases of basinal trend (see Fig. 4) a change from a confined to less confined basin conditions (see e.g., MARINI et alii, 2011, 2015). However, many evidences also suggest that although we are in a depositional zone, erosive processes and the generation of facies indicating local flow modifications related to impact, rebound, and reflective processes were active. These considerations derive from the geometry of the Agnone Basin in the investigated sector (see Fig. 24) that was tentatively reconstructed correlating a set of hydrocarbon exploration wells whose stratigraphic successions are characterized, from bottom to the top, by the Varicoloured Clays (VA), by the pre-flysch carbonate deposits (PFC), and by the turbidite deposits of the Agnone Flysch (AF) (Fig. 23).

The stratigraphic cross-sections of Fig. 24 show a raised sector of the basin that was bordered to the north and north-west by the Apennine carbonate platforms and a southern and south-eastern sector that constituted a more depressed and subsiding area where the highest thicknesses of the Agnone Flysch were deposited. The cross-sections a-a' and c-c' (NW-SE and N-S oriented respectively, Fig. 24) show the wedging and the onlap termination of the VM and PVM turbidite deposits towards the northern sectors of the basin. In particular the major thickness of mudstone deposits characterizing the VM is thought to be also an expression of the probable ponded effect against the frontal onlap of the basin when the latter shows the major confinement. With the aggradational phase and filling of the basin the VM and MPV are characterized by evident lateral facies change that passes, from up to downcurrent, from arenaceous and pelitic-arenaceous deposits of proximal lobes to the arenaceous-pelitic and pelitic deposits of distal lobe and lobe fringe respectively, thus highlighting a closure of turbidite deposits against the frontal slope of the basin. In other words, the aggradational arrangement of the VM lobes followed by the lobes progradational arrangement characterizing the lower portion of the PVM, would reflect the deposition within a confined basin, strongly supplied during a period of strong tectonic activity, 


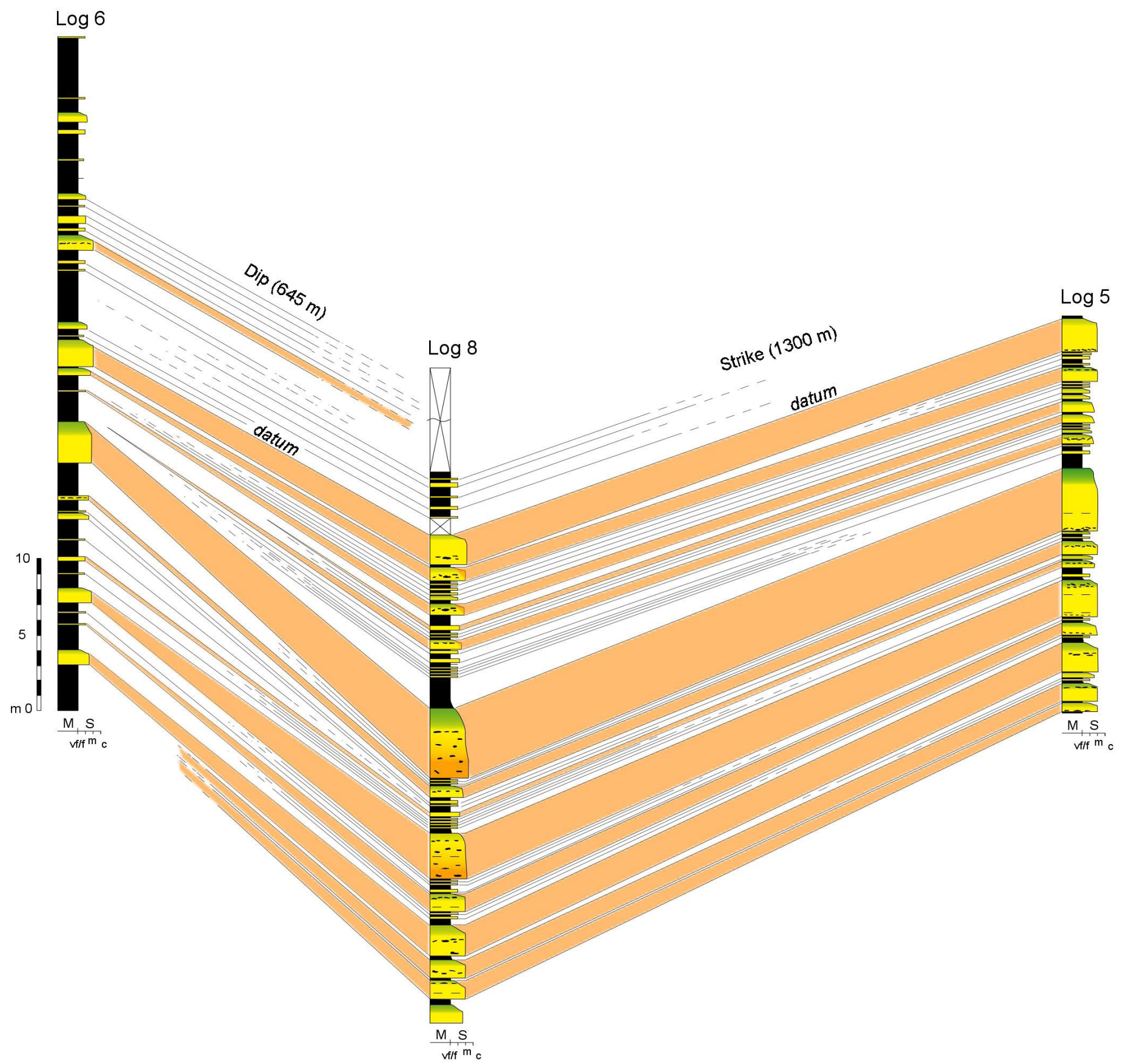

Fig. 22 - Detailed strike and dip oriented stratigraphic panel of the correlable portions of logs 6, 8, and 5. The panel shows the tabularity and lateral continuity of the sandstone bodies in strike section and their pinch out closure (downcurrent) in dip section.

as also suggested by compositional data and literature data (BARONE et alii, 2006; CRITELLI, 2018; SMERAGLIA et alii, 2019). Instead, the retrogradational lobe arrangement of the PVM upper portion and the SM would suggest a basin widening and a decrease of basin confinement with the following onlapping of the turbidite deposits onto the frontal and lateral margin of the basin.

The cross-section b-b' (WNW-ESE oriented; Fig. 24) shows a greater variability of the turbidite deposits thickness and an evident lateral change of facies moving from the western sectors to the eastern ones. Starting from the Rosello 1 well, the arenaceous facies are replaced by the pelitic-arenaceous and pelitic facies of the Tufillo Serra Palazzo and Daunia units respectively, which show very few intercalations of thin arenaceous layers. This suggests that such turbidite layers were essentially deposited onto a weakly inclined slope where the turbidite currents, now completely diluted, deposited the thin arenaceous layers onlapping onto the lateral slope of the basin.

A detailed analysis of the onlap geometries of the Agnone Basin is beyond the scope of this work and would require further data. Several studies have addressed this issue and defined numerous and possible styles of frontal and lateral onlap terminations of turbidite successions (PICKERING \& 

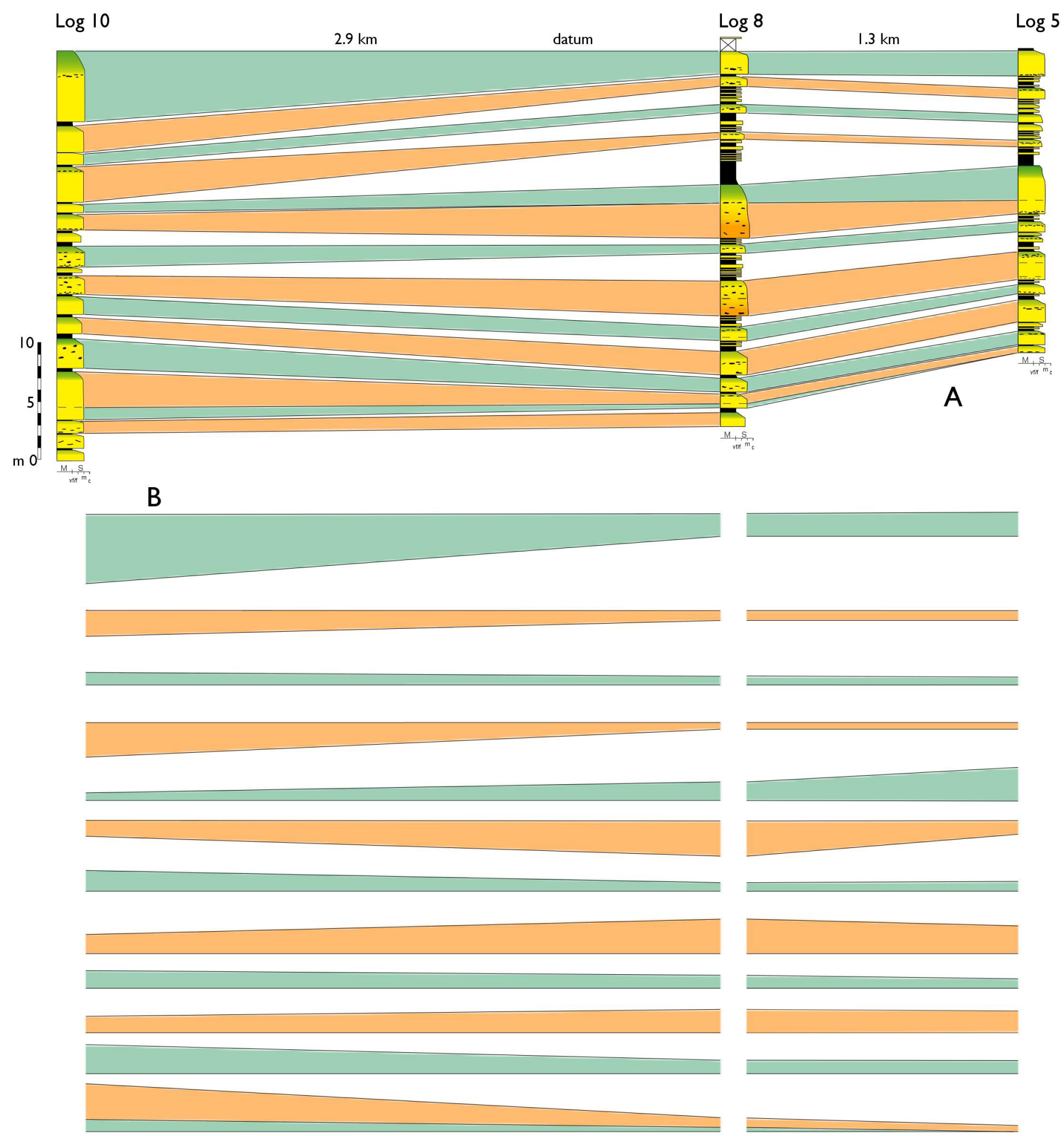

Fig. 23 - A) Detailed stratigraphic panel of the correlable portions of logs 10, 8, and 5. The panel is strike oriented (perpendicular to the paleocurrents). The panel has been correlated using a flattenning procedure for the thicker sandstone bodies that also containing mudstone clasts and muddy sandstone layers. B) The panel shows the geometry of these sandstone lobes, how they are laterally compensated and the position and concentration of the mudstone clasts.

Hilton, 1998; Kneller \& McCaffrey, 1999; Sinclair, 2000; Puigdefábregas et alii, 2004; SMith \& JosePh, 2004; BaKke et alii, 2013; PATACCI et alii, 2014, 2015). In our case, however, some preliminary considerations suggest that the northern frontal onlap of the basin would develop on a depositional slope of about $1.5^{\circ}$ that rose very slowly, so giving rise to an onlap termination similar to the "draping onlap" by BAKKE et alii (2013). This onlap termination would be coherent with the facies and geometry of the turbidite beds and with the aggradational-progradational trend recognized in the 


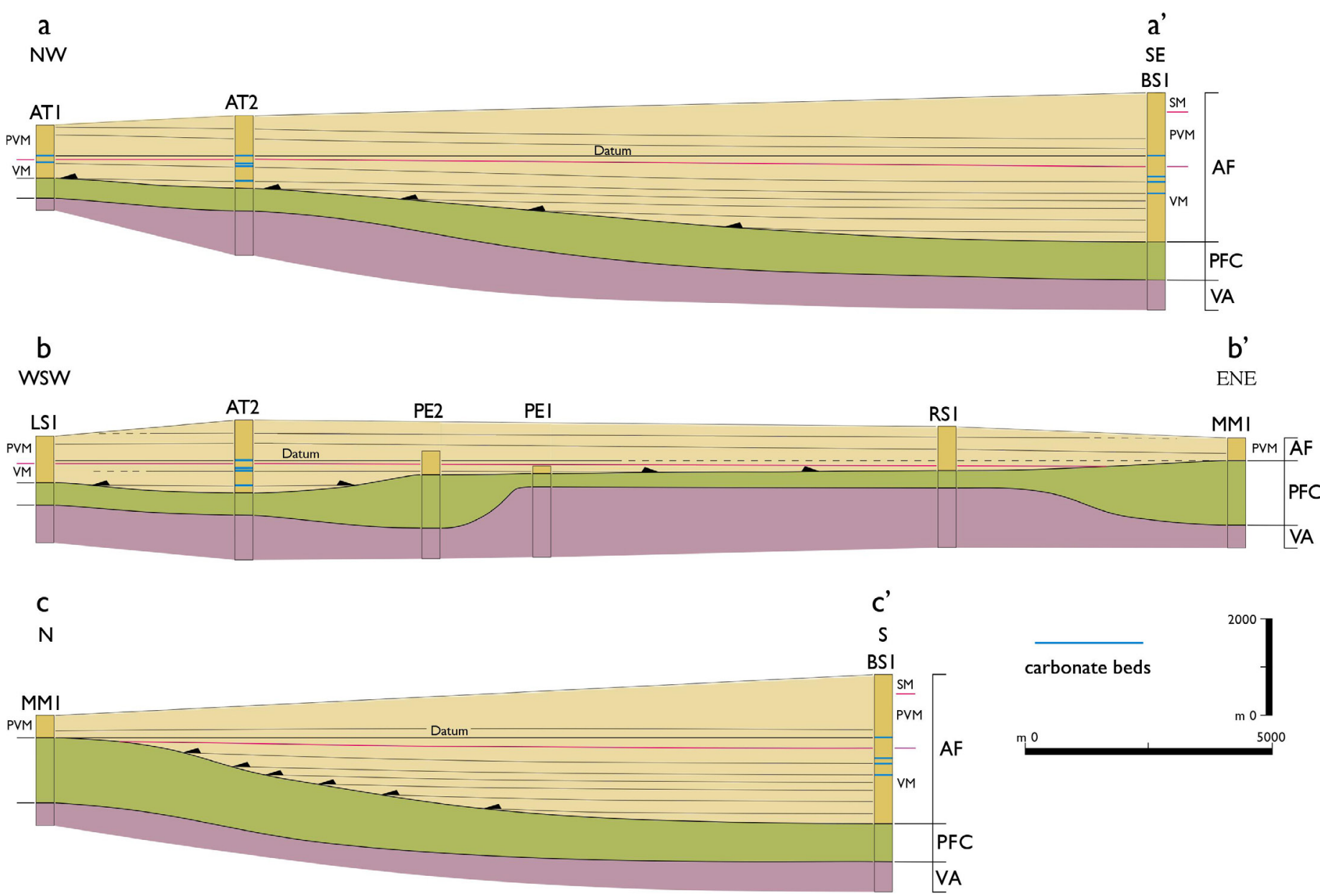

Fig. 24 - Stratigraphic cross-sections of the Agnone Basin oriented parallel (a-a' and c-c') and perpendicular (b-b') to flow directions. To note the onlap of the turbidite deposits onto the frontal and lateral margins of the basin. Wells: Ateleta1 (AT1), Ateleta2 (AT2), Belmonte del Sannio1 (BS1), Messer Marino1 (MM1), Pescopennataro1 (PE1), Pescopennataro2 (PE2), Rossello1 (RS1), Lago Saletta1 (LS1). VM: Verrino Member; PVM: Poggio Villanelle Member; SM: Sente Member. VA: Varicoloured Clay; PFC: Pre-Flysch Carbonate Deposits AF: Agnone Flysch.

VM and in the lower portion of the PVM.

Regarding the relationships between facies and basin geometry, we can say that they have many characters that record the interactions between flows and topography of the basin and/or the local depositional reliefs (lobes). In particular the facies FA1 e FA2 are the product of deposition of a rapidly aggrading high concentration basal layer of bipartite flows with different aggradation rate. They record a deceleration of the flows in correspondence of the frontal and lateral slope of the basin and mainly occur in the more depressed and subsiding sector of the basin; they characterize the proximal sectors and the axial/off-axial zones of lobes. Both these facies thinning downcurrent and laterally in the distal and distal fringe subenvironments and pass to the fine-grained laminated sand and mud (facies FA5 and FA6) that are deposited near and above the structural highs.

The facies FA3, FA4, and FA7 represent, for different reasons, the product of a close interaction between the topography of the basin and the flows, and record processes of erosion, rebound, and reflection of the flows in relation to their impact against both the lateral and frontal slopes of the basin, and against the same depositional reliefs (lobes). In this perspective, the degree of confinement of the Agnone Basin that changes during its vertical aggradation and filling phase, relegates these facies especially in the final portion of the Verrino member and in the initial and middle portion of Poggio Villanelle member. This occurred during a sedimentation phase in which the Agnone's turbiditic system is in a clear phase of aggradation and progradation due to the arrival of a major sediment supply that was probably linked with an increase of tectonic uplifting of the source areas, as also testified by the compositional data.

\section{CONCLUSIONS}

The integration of physical stratigraphy and facies analysis with sandstone petrography of the Agnone Flysch allowed to define the main depositional features, the main direction of sediment transport, and the source rocks 
composition supplying the Agnone turbidite deposits during the late Miocene, in the context of the southern Apennine evolution. The main results of this research are the following:

1) Facies analysis indicates that the turbidite deposits of the Agnone Flysch are characterized by seven main facies whose sedimentary characters together with geometry of the sandstone beds suggest their deposition in the lobe depositional zone, and in the sectors of the Agnone Basin where topographic confinement occurred. These facies and their lateral and vertical distribution are interpreted to reflect all the processes related to the flow deceleration against the depositional reliefs (lobes) and the frontal and lateral slope of a structurally-confined basin. This promoted the deposition of massive sandstones through hydraulic jumps as well as the by-passing of the turbulent portions of the flows which, impacting against the slopes of the basin, gave rise to the beds rich in mudstone clasts.

2) The stratigraphic organization of the Agnone Flysch broadly shows two main trends: a lower coarseningand thickening-upward trend which includes the arenaceous-pelitic portion of the VM and the peliticarenaceous and arenaceous portions of the PVM, and an upper fining- and thinning-upward trend, which includes the pelitic-arenaceous portion of the PVM and the arenaceous-pelitic and pelitic portions of the SM. This organization reflects a clear aggradational and progradational trend for the lower portion of the turbiditic succession which is believed being related to a continuous increase in sedimentary supply, in turn linked to a period of strong tectonic activity of the source areas and, more generally, to the eastward propagation of the Apennine thrusts. The upper portion, on the other hand, records a reduced sedimentary supply which could be linked to a decrease of tectonic activity, or even to a general lowering of the relief. At smaller scales, coarseningthickening and fining-thinning-upward trends are recognizable in the Agnone Flysch; in these cases, these trends can be ascribed either to autocyclic processes connected to the vertical and lateral overlap of the depositional lobes (compensational cycles by MutTi \& Sonnino, 1981), or to allociclic processes induced by climatic variations, in turn responsible for the variations in sedimentary supply. In this light the recognized large-scale trends in the Agnone Flysch are considered to be mainly controlled by tectonics (pulses of thrust migration), whereas the medium and small-scale trends could be mainly controlled by climatic, and intrinsic depositional dynamics of the turbidite system processes, respectively.

3) The paleocurrent data and the compositional analysis of the calcarenites and sandstones of the VM and PVM indicate that the former come from the western and north-western sectors of the basin where carbonate platforms of the Matese, Simbruini and western Marsica occurred. On the contrary the sandstone paleocurrent data, indicate a prevalent direction of flows from the southern sectors towards the northern sectors. This is consistent with the sandstones compositional data, which indicate the presence in the Tyrrhenian area of an emerged mountain range continuing in the sectors of the Calabrian Arc. This mountain range represented the main source area of detritus that fed the Agnone turbidite system essentially through hyperpycnal flows generated at the mouth of deltaic systems (Fig. 25), fed by rivers with high-gradient small drainage basins, occurred along this tectonically active margin (e.g. Milliman AND SyvitSKY, 1992; Bornhold et alii, 1994; Mulder \& Syvitsky, 1995; Mulder et alii, 2003; Mutti et alii, 1994, 1996, 2000, 2003; PARson et alii, 2001; Hizzet et alii, 2018; MutтI, 2019). This depositional context is very similar to the present Calabrian Ionian margin (PERRi et alii, 2012a; CRITELli, 2018), a tectonically active margin characterized by small- and mediumsized mountainous rivers (Fiumare), at the mouth of which occur the head of canyons, which constitute the main transit routes of fluvial flood events that should generate hyperpycnal flows and in turn turbidite currents.

4) The topography of the Agnone Basin in the investigated area can be subdivided in at least four sectors: 1) a raised northern sector, forming the frontal slope of the basin, transitionally passing to the drowned carbonate platforms of the central Apennine constituting structural highs in the foredeep basin, where the Agnone turbidite deposits onlapped; 2) a western sector, just close to the Apennine thrusts from which sediment gravity flows derived, giving rise to the calcarenite beds and olistoliths occurring within the Agnone Flysch; 3) an eastern sector transitionally passing to a low gradient slope with mudstone sedimentation on which the most diluted and distal portions of the turbidite flows deposited and onlapped (mudstone and muddy-siltstone facies of the coeval Tufillo-Serra Palazzo and Daunia units). The latter sector passed further eastward to the carbonate pelagic and shallow water sedimentation areas of the Apulia Platform; 4) a southern and more depressed and subsiding sector which constituted the depocentral area of the basin, where the bulk thickness of the Agnone turbidite deposits was accommodated. This geometry of the basin is evident from the stratigraphic cross-sections of Fig. 24, which show how the Agnone Basin was stretched in the N-S direction having a raised sector to the north and a depressed sector to the south.

In conclusion, the study of the turbidite deposits of Agnone Flysch has allowed us to expand the sedimentological and stratigraphic knowledge of this formation having better characterized: i) the types of facies and the relative depositional mechanisms; ii) the main architectural elements of this turbidite depositional system; iii) the paleocurrent directions and the source areas supplying these turbidite flows and finally iv) the sandstone and mudstone composition. All these data suggest that this turbidite succession was deposited in a confined basin within the larger foredeep LagonegroMolise Basin. These observations suggest that this basin presented an articulated geometry and an asymmetric shape in the W-E section, with the most depressed sector close to the Apennine thrust front and a sector with a slight gradient towards the east that passed laterally to the Apulia Platform (Fig. 25). 


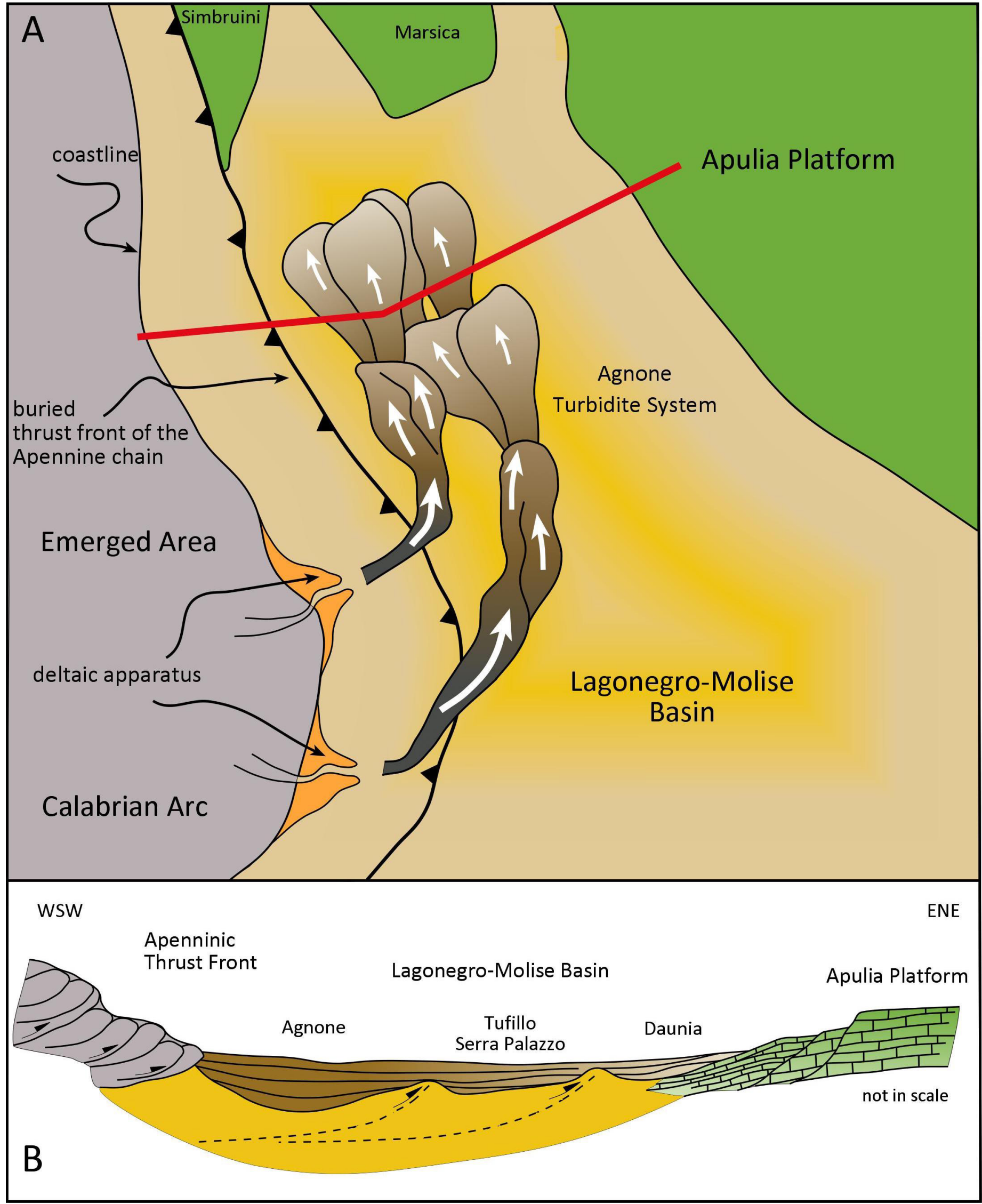

Fig. 25 - A) Paleogeographic scheme showing the possible feeding areas of Agnone Flysch according to paleocurrent data and sandstone composition. The red line indicates the trace of section B. B) Section showing the stratigraphic relationships between Agnone's Flysch and the clayey-silty and clayey deposits of the Tufillo Serra Palazzo and Daunia units. Note the onlap of turbidite deposits onto the lateral slope of the basin which makes the transition to the western sector of the Apulia Platform. 


\section{ELECTRONIC SUPPLEMENTARY MATERIAL}

This article contains electronic supplementary material which is available to authorised users.

\section{ACKNOWLEDGMENTS}

This research was partly funded by SAPIENZA University of Rome and by Norske Shell and Statoil (now Equinor). We thanked the reviewers Luca Aldega and Etta Patacca as well as the Associate Editor (Domenico Cosentino) for their constructive comments of the manuscripts, although the reported interpretations are to be attributed only to the responsibility of the authors . G.C. was supported by the POR FSE/FESR 2014/2020 related to her PhD Program at the PhD Course on "Science and Engineering of the Environment, Building and Energy" (SIACE) at the University of Calabria. The senior Author (S.M.) would like to thank all the colleagues who have discussed with him, in recent years, of the turbidite deposits of the central-southern Apennines, and in particular Emiliano Mutti, Franco Ricci Lucchi, Massimiliano Moscatelli, Mattia Marini and Roberto Tinterri.

\section{REFERENCES}

Artchison J., (1997) - The one-hour course in compositional data analysis or compositional data analysis is simple. In: PawlowsKy-Glahn V. (ed.), Proceedings of IAMG '97 - The third annual conference of the International Association for Mathematical Geology, vol. I, II and addemdum. International Center for Numerical Methods in Engineering (CIMNE), Barcelona, Spain, 3-35.

Accaino F., Catalano R., Di Marzo L., Giustiniani M., Tinivella U., Nicolich R., Sulli A., Valenti V. \& Manetti P. (2011) - A crustal seismic profile across Sicily. Tectonophysics, 508, 52-61.

Aldega L., Botti F. \& Corrado S. (2007) - Clay mineral assemblages and vitrinite reflectance in the Laga Basin (Central Apennines, Italy): What do they record? Clay and Caly Minerals, 55, 504-518.

Aldega L., Brandano M. \& Cornacchia I. (2020) - Trophism, climate and paleoweathering conditions across the Eocene-Oligocene transition in the Massignano section (northern Apennines, Italy). Sedimentary Geology, 405, 105701.

Allen J.R.L. (1982) - Sedimentary Structures: their character and physical basis. Developments in Sedimentology, 30, v. II, 663 pp.

Amendola U., Perri F., Critelli S., Monaco P., Cirilli S., Trecci T. \& RetToRi R. (2016) - Composition and provenance of the Macigno Formation (Late Oligocene-Early Miocene) in the Trasimeno Lake area (Northern Apennines). Marine and Petroleum Geology, 69,146-167.

Aмоre O. (1992) - Studi biostratigrafici dei sedimenti miocenici del bacino molisano: nannoplancton calcareo. Ph.D Thesis, Università di Napoli, $95 \mathrm{pp}$.

Amy L.A. \& TAlLing P.J. (2006) - Anatomy of turbidites and linked debrites based on long distance $(120 \times 30 \mathrm{~km})$ bed correlation, Marnosoarenacea Formation, Northern Apennines, Italy. Sedimentology, 53, 161-212.

ARNotT R.W.C. \& Hand B.M. (1989) - Bedforms, primary structures and grain fabric in the presence of suspended sediment rain. Journal of Sedimentary Research, 59, 1062-1069.

Baas J.H., Best J.L., Peakall J. \& Wang M. (2009) - A phase diagram for turbulent, transitional, and laminar clay suspension flows. Journal of Sedimentary Research, 79, 162-183.

BaAs J.H., Best J.L. \& Peakall J. (2011) - Depositional processes, bedform development and hybrid bed formation in rapidly decelerated cohesive (mud-sand) sediment flows. Sedimentology, 58, $1953-1987$.

Bakke K., Kane I.A., Martinsen O.J. Petersen S.A., Johansen T.A., Hustoft S. \& Groth A. (2013) - Seismic modeling in the analysis of deep-water sandstone termination styles. American Association of Petroleum Geologists Bulletin, 97, 1395-1419.

Barone M., Critelli S., Le Pera E., Di nocera S., Matano F. \& Torre M. (2006) - Stratigraphy and detrital modes of Upper Messinian postevaporitic sandstones of the Southern Apennines, Italy: evidence of foreland-basin evolution during the Messinian Mediterranean salinity crisis. International Geology Review, 48, 702-724.
Barone M., Dominici R., Muto F. \& Critelli S. (2008) - Detrital modes in a late Miocene wedge-top basin, northeastern Calabria, Italy: compositional record of wedge-top partitioning. Journal of Sedimentary Research, 78, 693-711.

Bigi S., Costa Pisani P., Milli S. \& Moscatelli M. (2003) - The control exerted by prethrusting normal faults on the Early Messinian foredeep evolution, structural styles and shortening in the Central Apennines (Lazio-Abruzzo, area, Italy). Studi Geol. Camerti, Numero Speciale 2003, 17-37.

Bigi S., Milli S., Corrado S., Casero P., Aldega L., Botti F., Moscatelli M., Stanzione O., Falcini F., Marini M. \& Cannata D. (2009) Stratigraphy, structural setting and burial history of the Messinian Laga basin in the context of Apennine foreland basin system. Journal of Mediterranean Earth Sciences, 1, 61-84.

Billi A., Tiberti M.M., Cavinato G.P., Cosentino D., Di Luzio E., Keller J.V.A. \& WARDELL N. (2006) - First results from the CROP-11 deep seismic profile, central Apennines, Italy: Evidence of mid-crustal folding. Journal of the Geological Society, 163, 583-586.

BoIANo U. (1997) - Anatomy of a siliciclastic turbidite basin: the Gorgoglione Flysch, Upper Miocene, southern Italy: physical stratigraphy, sedimentology and sequence stratigraphy framework. Sedimentary Geology, 107, 231-262.

Bonardi G., Ciarcia S., Di Nocera S., Matano F., Sgrosso I. \& Torre M. (2009) - Carta delle principali unità cinematiche dell'Appennino Meridionale. Nota illustrativa. Bollettino della Società Geologica Italiana, 128, 47-60.

Bornhold B.D., Ren P. \& PRIOR D.B. (1994) - High-frequency turbidity currents in British Columbia fjiords. Geo-Marine Letters, 14, 238243.

Boogaart K.G.v.d. \& Tolosana-Delgado R. (2008) - Compositions': a unified $R$ package to analyze compositional data. Computer \& Geosciences, 34, 320-338.

Butler R.W.H. \& TAVARnelli E. (2006) -_The structure and kinematics of substrate entrainment into high-concentration sandy turbidites: a field example from the Gorgoglione 'flysch' of southern Italy. Sedimentology, 53, 655-670.

Caracciolo L., Critelli S., Innocenti F., Kolios N. \& Manetti P. (2011) - Unravelling provenance from Eocene-Oligocene sandstones of the Thrace Basin, north-east Greece. Sedimentology, 58, 1988-2011.

Caracciolo L., Von Eynatten H., Tolosana-Delgado R., Critelli S., Manetti P. \& Marchev P. (2012) - Petrological, geochemical, and statistical analysis of Eocene-Oligocene sandstones of the Western Thrace Basin, Greece and Bulgaria. Journal of Sedimentary Research, 82, 482-498.

Caracciolo L., Gramigna P., Critelli S., Calzona A.B. \& Russo F. (2013) - Petrostratigraphic analysis of a Late Miocene mixed siliciclasticcarbonate depositional system (Calabria, Southern Italy): implications for Mediterranean paleogeography. Sedimentary Geology, 284-285,117-132.

Casciano C.I., Patacci M., Longhitano S.G., Tropeano M., McCaffrey W.D. \& Di Celma C. (2019) - Multi-scale analysis of a migrating submarine channel system in a tectonically-confined basin: The Miocene Gorgoglione Flysch Formation, southern Italy. Sedimentology, 66, 205-240.

Casero P., Roure F., Endignoux L., Moretti I., Muller C., Sage L. \& VIALLY R. (1988) - Neogene geodynamic evolution of the Southern Apennines. Memorie della Società Geologica Italiana, 41, 109120.

Cavalcante F., Fiore S., Lettino A., Piccarreta G. \& Tateo F. (2007) Illite-Smectite mixed layer in Sicilide shales and piggy-back deposits of the Gorgoglione Formation (Southern Apennines): geological inferences. Bollettino della Società Geologica Italiana, 103, 241254.

Cifelli F., Mattei M. \& Rossetti F. (2007) - Tectonic evolution of arcuate mountain belts on top of a retreating subduction slab: the example of the Calabria Arc. Journal of Geophysical Research, 112, B09101.

Civitelli G. \& CoRda L. (1988) - Successioni flyschoidi e complessi alloctoni. In: Accordi G., Carbone F., Civitelli G., Corda L., De Rita D., Esu D., Funiciello R., Kotsakis T., Matiotti G. \& Sposato A. (eds.), Note illustrative alla Carta delle Litofacies del Lazio-Abruzzo ed aree limitrofe. C.N.R., Quaderni de La Ricerca Scientifica, 114, 5, 93-168.

Clermonté J. \& Pironon B. (1979) - La plate-forme campano-abruzzaise de la Meta au Matese (Italie meridionale); differenciations au 
Paleogene et au Miocene, structures, relations avec les formations molisanes. Bulletin de la Société Géologique de France S7-XXI 737-743.

Corrado S., Aldega L. \& Zattin M. (2010) - Sedimentary vs. tectonic burial and exhumation along the Apennines (Italy). In: Beltrando M., Peccerillo A., Mattei M., Conticelli S. \& Doglioni C. (eds.), The Geology of Italy: Tectonics and Life Along Plate Margins. Journal of the Virtual Explorer, Electronic Edition, ISSN 1441-8142, 36 paper 152010.

Corrado S., Di Bucci D., Naso G., Giampaolo C. \& Adatte T. (1998) Application of organic matter and clay mineral studies to the tectonic history of the Abruzzo-Molise-Sannio area, Central Apennines, Italy. Tectonophysics, 285, 167-181.

Corrado S., Aldega L., Perri. F., Critelli S., Muto F., Schito A. \& TRIPODI V. (2019) - Detecting syn-orogenic extension and sediment provenance of the Cilento wedge top basin (southern Apenninies, Italy): Mineralogy, and geochemistry of fine-grained sediments and petrography of dispersed organic matter. Tectonophysics, 750, 404-418.

Cosentino D., Carboni M.G., Cipollari P., Di Bella L., Florindo F. LAURENZI M.A. \& SAGNOTTI L. (1997) - Integrated stratigraphy of the Tortonian-Messinian boundary: the Pietrasecca composite section (central Apennines, Italy). Eclogae Geologicae Helvetiae, 90, 229. 244.

CRITELLI S. (1991) - Evoluzione delle mode detritiche delle successioni arenitiche terziarie dell'Appennino meridionale. Memorie della Società Geologica Italiana, 47, 55-93.

CRITELLI S. (1993) - Sandstone detrital modes in the Paleogene Liguride Complex, accretionary wedge of the Southern Apennines (Italy). Journal of Sedimentary Petrology, 63, 464-476.

CRITELLI S. (1999) - The interplay of lithospheric flexure and thrust accomodation in forming stratigraphic sequences in the southern Apennines foreland basin system, Italy. Accademia Nazionale de Lincei, Rendiconti Lincei Scienze Fisiche e Naturali,10, 257-326.

Critelli S. (2015) - Flysch del Molise. In: Sgrosso I., Naso, G. (eds.), Note Illustrative della Carta Geologica d'Italia alla scala 1:50.000, F. 393 Trivento, 51-52.

CRITelli S. (2018) - Provenance of Mesozoic to Cenozoic CircumMediterranean sandstones in relation to tectonic setting. EarthScience Reviews, 185, 624-648.

CRitelli S. \& INGERSoll R.V. (1994) - Sandstone petrology and provenance of the Siwalik Group (northwestern Pakistan and western-southeastern Nepal). Journal of Sedimentary Research, A64,815-823.

CRItelli S. \& Le PeRA E. (1990) - Litostratigrafia e composizione della Formazione di Pollica (Gruppo del Cilento, Appennino meridionale). Bollettino della Societa' Geologica Italiana, 109, 511-536.

Critelli S. \& Le Pera E. (1994) - Detrital modes and Provenance of Miocene sandstones and Modern sands of the Southern Apennines thrust-top basins (Italy). Journal of Sedimentary Research, A64 824-835.

Critelli S. \& Le Pera E. (1995a) - Tectonic evolution of the Southern Apennines thrust-belt (Italy) as reflected in modal compositions of Cenozoic sandstone. The Journal of Geology, 103, 95-105.

Critelli S. \& Le Pera E. (1995b) - La Formazione di Castelvetere nell'evoluzione petrostratigrafica dell'avanfossa del TortonianoMessiniano dell'Appennino meridionale. Bollettino della Società Geologica Italiana, 114, 615-634.

Critelli S. \& Le Pera E. (1998) - Post-Oligocene sediment dispersal systems and unroofing history of the Calabrian Microplate, Italy. International Geology Review, 48, 609-637.

Critelli S., De Rosa R., \& Platt J.P. (1990a) - Sandstone detrital modes in the Makran accretionary wedge, southwest Pakistan: implications for tectonic setting and long-distance turbidite transportation. Sedimentary Geology, 68, 241-260.

Critelli S., De Rosa R., Sonnino M. \& Zuffa G.G. (1990b) - Significato dei depositi vulcanoclastici della Formazione delle Tufiti di Tusa (Miocene inferiore, Lucania meridionale). Bollettino della Societa' Geologica Italiana, 109, 743-762.

Critelli S., De Capoa P., Le Pera E. \& Perrone V. (1994) - Stratigrafia e petrografia delle Arenarie di Albanella (Valle del F. Calore, Appennino Campano). Bollettino della Societa' Geologica Italiana, 113, 451463.

Critelli S., Le Pera E., Galluzzo F., Milli S., Moscatelli M., Perrotta S. \& Santantonio M. (2007) - Interpreting siliciclastic-carbonate detrital modes in Foreland Basin Systems: an example from Upper Miocene arenites of the Central Apennines, Italy. In: ArRIBAS J., CRITElli S. \& Johnsson M. (eds.), Sedimentary Provenance: Petrographic and Geochemical Perspectives. Geological Society of America Special Paper, 420, 107-133.

Critelli S., Mongelli G., Perri F., Martin-Algarra A., Martin-Martin M., Perrone V., Dominici R., Sonnino M. \& Zaghloul M.N. (2008) - Sedimentary evolution of the Middle Triassic -Lower Jurassic continental redbeds from Western-Central Mediterranean Alpine Chains based on geochemical, mineralogical and petrographical tools. Journal of Geology, 116, 375-386.

Critelli S., Muto F., Tripodi V. \& Perri F. (2011) - Relationships between lithospheric flexure, thrust tectonics and stratigraphic sequences in foreland setting: the Southern Apennines foreland basin system, Italy. In: SchatTNER U. (ed.), New Frontiers in Tectonic Research at the Midst of Plate Convergence. Intech Open Access Publisher, Janeza Trdine 9, Rijeka, Croatia, 121-170.

Critelli S., Muto F., Tripodi V. \& Perri F. (2013) - Link between thrust tectonics and sedimentation processes of stratigraphic sequences from the southern Apennines foreland basin system, Italy. Rendiconti Online della Società Geologica Italiana, 25, 21-42.

Critelli S., Muto F., Perri F. \& Tripodi V. (2017) - Interpreting provenance relations from sandstone detrital modes, southern Italy foreland region: stratigraphic record of the Miocene tectonic evolution. Marine and Petroleum Geology, 87, 47-59.

CULLERS R.L. (1994a) - The chemical signature of source rocks in size fractions of Holocene stream sediment derived from metamorphic rocks in the Wet Mountains region USA. Chemical Geology, 113, 327-343.

Cullers R.L. (1994b) - The controls on the major and trace element variation of shales, siltstones, and sandstones of PennsylvanianPermian age from uplifted continental blocks in Colorado to platform sediment in Kansas, USA. Geochimimica et Cosmochimica Acta, $\mathbf{5 8}, 4955-4972$.

CULLERS R.L. (1995) - The controls on the major-and trace-element evolution of shales, siltstones and sandstones of Ordovician to Tertiary age in the Wet Mountains region, Colorado, U.S.A. Chemical Geology, 123, 107-131.

Cullers R.L. \& PodKovyrov V.N. (2002) - The source and origin of terrigenous sedimentary rocks in the Mesoproterozoic Ui group, southeastern Russia. Precambrian Research, 117, 157-183.

D'Argenio B., Pescatore T. \& Scandone P. (1973) - Schema geologico dell'Appennino Meridionale (Campania e Lucania). Atti del Convegno "Moderne vedute sulla geologia dell'Appennino" (Roma 16-18 Febbraio 1972), Accademia Nazionale del Lincei, Quaderno, 183, 49-72.

Dal Piaz, G.V, Del Moro A., Di Sabatino B., Sartori R. \& Savelli C. (1983) - Geologia del Monte Flavio Gioia (Tirreno centrale). Memorie di Scienze Geologiche dell'Università di Padova, 35, 429-452.

Dewey J.F., Helman M.L., Turco E., Hutton D.H.W. \& Knott S.D. (1989) - Kinematics of the western Mediterranean.: In: CowARD M.P., Dietrich D. \& PARK R.G. (eds.), Alpine Tectonics. Geological Society, London, Special Publications, 45, 265 -283.

Di BuccI D. (1995) - Rapporti tra piattaforme carbonatiche e "Alloctono" lungo la media valle del Sangro. Bollettino della Societa Geologica Italiana, 114, 443-463.

Di Bucci D., Parotto M., Adatte T., Giampaolo C. \& Kübler B. (1996) Mineralogia della Argille Varicolori dell'Appennino centrale: risultati preliminari e prospettive di ricerca. Bollettino della Società Geologica Italiana, 115, 689-700.

Dickinson W.R. (1970) - Interpreting detrital modes of graywacke and arkose. Journal of Sedimentary Petrology, 40, 695-707.

DicKINSON W.R. (1985) - Interpreting provenance relations from detrital modes of sandstones. In: ZUFFA G.G. (ed.), Provenance of Arenites. Nato Asi series, 148, D. Reidel Publ. Co., 333-361.

Dickinson W.R. (1988) - Provenance and sediment dispersal in relation to paleotectonics and paleogeography of sedimentary basins. In: Kleinspehn K.L. \& PaOla C. (eds.), New Perspectives in Basin Analysis. Springer-Verlag, New York, 3-25.

DoRsey R.J. (1988) - Provenance evolution and unroofing history of a modern arc-continent collision: evidence from petrography of PlioPleistocene Sandstones, Eastern Taiwan. Journal of Sedimentary Petrology, 58, 208-218. 
Edwards D.A., Leeder M.R., Best J.L. \& Pantin H.M. (1994) - On experimental reflected density currents and the interpretation of certain turbidites. Sedimentology, 41, 437-461.

FABBi S. (2016) - Geology of the Northern Simbruini Mts. (AbruzzoItaly). Journal of Maps, 12, 441-452.

FABBI S. \& Rossi M. (2014) - The Brecce della Renga Formation: age and sedimentology of a syn-tectonic clastic unit in the upper Miocene of Central Apennines. Insights from field geology. Rivista Italiana di Paleontologia e Stratigrafia, 120, 225-242.

FabBi S. \& SANTANTONIO M. (2019) - First report of a Messinian coralgal facies in a terrigenous setting of Central Apennines (Italy) and its palaeogeographic significance. Geological Journal, 54, 1756-1768.

FabBi S., Galluzzo F., Pichezzi R.M., \& Santantonio M. (2014) Carbonate intercalations in a terrigenous foredeep: Late Miocene examples from the Simbruini Mts. and the Salto Valley (Central Apennines-Italy). Italian Journal of Geosciences, 133, 85-100.

Faccenna C., Becker T.W., Lucente F.P., Jolivet L. \& Rossetti F. (2001) - History of subduction and back-arc extension in the Central Mediterranean. Geophysical Journal International, 145, 809-820.

Falcini F., Marini M., Milli S. \& Moscatelli M. (2009a) - An inverse problem to infer paleoflow conditions from turbidites. Journal of Geophysical Research: Oceans, 114, C10019.

Falcini F., Milli S., Moscatelli M. \& Stanzione O. (2009b) - On the possibility of inferring paleoflow conditions from turbidite deposits. an example from the Laga Formation (Central Apennines, Italy). In: Kneller B., Martinsen O.J. \& McCaffrey, B. (eds.), External Controls on Deep-Water Depositional Systems. SEPM (Society for Sedimentary Geology), Special Publication 92, 347-362.

Fonnesu M., Haughton P.D.W., Felletti F. \& McCaffrey W.D. (2015) - Short length-scale variability of hybrid event beds and its applied significance. Marine and Petroleum Geology, 67, 583-603.

Fonnesu M., Patacci M., Haughton P.D.W., Felletti F. \& McCaffrey W.D. (2016) - Hybrid event beds generated by local substrate delamination on a confined-basin floor. Journal of Sedimentary Research, 86, 929-943.

Fonnesu M., Felletti F., Haughton P.D.W, Patacci M., \& McCaffrey W.D. (2018) - Hybrid event bed characters and distribution linked to turbidite system sub-environments: the north Apennine Gottero sandstone (north-west Italy). Sedimentology, 65, 151-190.

Fornelli A. \& Piccarreta G. (1997) - Mineral and chemical provenance in some early Miocene sandstones of the southern Apennines (Italy). European Journal of Mineralogy, 9, 433-447.

Gazzi P. (1966) - Le arenarie del flysch sopracretaceo dell'Appennino modenese: correlazioni con il flysch di Monghidoro. Mineralogica et Petrographica Acta, 12, 69-97.

Gladstone C., Mcclelland H.L.O., Woodcock N.H., Pritchard D. \& HunT J.E. (2018) - The formation of convolute lamination in mudrich turbidites. Sedimentology, 65, 1800-1825.

Handy M.R., Schmid S.M., Bousouet R., Kissling E. \& Bernoulli D. (2010) - Reconciling plate-tectonic reconstructions of Alpine Tethys with the geological-geophysical record of spreading and subduction in the Alps. Earth-Science Reviews, 102, 121-158.

HaUghton P.D.W., BAKER S.P. \& McCAFFREY W.D. (2003) - Linked debrites in sand-turbidite systems - origin and significance. Sedimentology, 50, 459-482.

Haughton P., Davis C., McCaffrey W. \& Barker S. (2009) - Hybrid sediment gravity flow deposits-classification, origin and significance. Marine and Petroleum Geology, 26, 1900-1918.

Hizzett J.L., Hughes Clarke J.E., Sumner E.J., Cartigny M.J.B., Talling P.J. \& Clare M.A. (2018) - Which triggers produce the most erosive, frequent, and longest runout turbidity currents on deltas? Geophysical Research Letters, 45, 855- 863.

Hodgson D.M. (2009) - Distribution and origin of hybrid beds in sandrich submarine fan of the Tanqua depocentre, Karoo Basin, South Africa. Marine and Petroleum Geology, 26, 1940-1956.

Ingersoll R.V. \& SuczeK C.A. (1979) - Petrology and provenance of Neogene sand from Nicobar and Bengal fans, DSDP sites 211 and 218. Journal of Sedimentary Petrology, 49, 1217-1228.

Ingersoll R.V., Bullard T.F., Ford R.L, Grimm J.P, Pickle J.D. \& Sares S.W. (1984) - The effect of grain size on detrital modes: a test of the Gazzi-Dickinson Point-Counting Method. Journal of Sedimentary Petrology, 54, 103-116.

JADGOZINSKI H. (1949) - Eindimensionale Fehlordnung in Kristallen und ihr Einfluss auf die Rontgeninterferenzen. I Berechnung des Fehlordnunsgrades aus der Rontgenintensitaten. Acta Crystallographica, 2, 201-207.

Johansonn M. \& Stow D.A.V. (1995) - A classification scheme for shale clasts in deep water sandstones. In: HartLey A.J. \& Prosser D.J. (eds.), Characterization of Deep Marine Clastic Systems. Geological Society, London, 94, 221-241.

Kane I., Pontén A., Vangdal B., Eggenhuisen J., Hodgson D.M. \& SPYchaLA Y.T. (2017) - The stratigraphic record and processes of turbidity current transformation across deep-marine lobes. Sedimentology, 64, 1236-1273.

KNELLER B. (1995) - Beyond the turbidite paradigm: physical models for deposition of turbidite and their implications for reservoir prediction. In: HARTLEy A.J. \& Prosser D.J. (eds.), Characterization of Deep Marine Clastic Systems. Geological Society, London, 94, 31-49.

KNeller B.C. \& Branney M.J. (1995) - Sustained high-density turbidity currents and the deposition of thick massive sands. Sedimentology, 42, 607-616.

KNELleR B. \& MCCAFFREY W. (1999) - Depositional effects of flow nonuniformity and stratification within turbidity currents approaching a bounding slope: deflection, reflection, and facies variation. Journal of Sedimentary Research, 69, 980-991.

KRUMm S. (1996) - WINFIT 1.2: version of November 1996 (The Erlangen geological and mineralogical software collection) of "WINFIT 1.0: a public domain program for interactive profile-analysis under WINDOWS". XIII Conference on clay mineralogy and petrology, Praha, 1994, 38. Acta Universitatis Carolinae Geologica, 253-261.

Laviano R. (1987) - Analisi mineralogica quantitativa di argille mediante diffrattometria di raggi $X$. Atti workshop: Procedure di analisi di materiali argillosi. ENEA S.Teresa, Lerici (SP), 1-2/06/1987, 215-34.

LeZZERINI M., Sartori F \& TAMPoni M. (1995) - Effect of amount of material used on sedimentation slides in the control of illite "crystallinity" measurements. European Journal of Mineralogy, 7, 819-823.

Lowe D.R. \& GuY M. (2000) - Slurry-flow deposits in the Britannia Formation (Lower Cretaceous), North Sea: a new perspective on the turbidity current and debris flow problem. Sedimentology, 47, $31-70$.

Lustrino M., Morra V., Fedele L. \& Franciosi L. (2009) - The beginning of the Apennine subduction system in central-western Mediterranean: constraints from Cenozoic "orogenic" magmatic activity of Sardinia (Italy). Tectonics, 28, TC5016.

Marini M., Milli S. \& Moscatelli M. (2011) - Facies and architecture of the Lower Messinian turbidite lobe complexes from the Laga Basin (central Apennines, Italy). Journal of Mediterranean Earth Sciences, 3, 45-72.

Marini M., Milli S., Ravn̊̊s R. \& Moscatelli M. (2015) - A comparative study of confined vs. semi-confined turbidite lobes from the Lower Messinian Laga Basin (Central Apennines, Italy): implications for assessment of reservoir architecture. Marine and Petroleum Geology, 63, 142-165.

Marini M., Milli S., Moscatelli M., Patacci M.\& McCaffrey W.D. (2012) - Facies and processes from the confined Salto-Tagliacozzo Basin (Messinian, Central Apennines, Italy). Rendiconti Online della Società Geologica Italiana, 21, 906-908.

Marsella E., Bally A.W., Cippitelli G., D’Argenio B. \& Pappone G. (1995) - Tectonic history of the Lagonegro domain and Southern Apennine thrust belt evolution. Tectonophysics, 252, 307-33.

MarschaLko R. (1970) - The origin of disturbed structures in carpathian turbidites. Sedimentary Geology, 4, 5-18.

Mattei M., Cifelli F. \& D'Agostino N. (2007) - The evolution of the Calabrian Arc: evidence from paleomagnetic and GPS observations. Earth and Planetary Science Letters, 263, 259-274.

Matano F., Critelli S., Barone M., Muto F. \& Di Nocera S. (2014) Stratigraphic and provenance evolution of the Southern Apennines foreland basin system during the Middle Miocene to Pliocene. Marine and Petroleum Geology, 57, 652-670.

Matano F., Di Nocera S., Criniti S. \& Critelli S. (2020) - Geology of the epicentral area of the 1980 earthquake (Irpinia, Italy): new stratigraphical, structural and petrological constrains. MDPI Geosciences 10, 1-33 [doi:10.3390/geosciences10060247].

Mazzoli S., D’Errico M., Aldega L., Corrado S., Invernizzi C., Shiner P. \& ZatTin M. (2008) - Rtectonic burial and "young" (<10 Ma) exhumation in the southern Apennines fond-andthrust belt (Italy). Geology, 36, 243-246. 
Mazzoli S., Barkham S., Cello G., Gambini R., Mattioni L., Shiner P., \& ToNDI E. (2001) - Reconstruction of continental margin architecture deformed by the contraction of the Lagonegro Basin, southern Apennines, Italy. Journal of the Geological Society, 158, 309-319.

MCLENNAN S.M. (1989) - Rare earth elements in sedimentary rocks: Influence of provenance and sedimentary processes. Mineralogy Society of America, Reviews in Mineralogy, 21, 169-200.

McLennan S.M., Hemming S., McDaniel D.K. \& Hanson G.N. (1993) - Geochemical approaches to sedimentation, provenance, and tectonics. In: Johnson M.J. \& Basu A. (eds.), Processes Controlling the Composition of Clastic Sediments. Geological Society of America Special Paper, 284, 21-40.

Merriman R.J. (2005) - Clay minerals and sedimentary basin history. European Journal of Mineralogy, 17, 7-20.

Merriman R.J. \& Frey M. (1999) - Patterns of very lo-grade metamorphism in metapelitic rocks. In: Frey M. \& Robinson D. (eds.), Low Grade Metamorfism. Blackwell, Oxford, 61-107).

Middleton G.V. (1967) - Experiments on density and turbidity currents: III. Deposition of sediments. Canadian Journal of Earth Sciences, 4, 475-505.

Milliman J.D. \& Syvitsky J.P.M. (1992) - Geomorphic and tectonic control of sediment discharges to the ocean: the importance of small mountain rivers. Journal of Geology, 100, 525-544.

Milli S. (2015) - Analisi sedimentologiche. In: Sgrosso I., Naso, G. (eds.), Note Illustrative della Carta Geologica d'Italia alla scala 1:50.000, F. 393 Trivento, 38-44.

Milli S. \& Moscatelli M. (2000) - Facies analysis and physical stratigraphy of the Messinian ramp turbiditic complex in the Valle del Salto and Val di Varri (central Apennines). Giornale di Geologia 62, 57-77.

Milli S. \& Moscatelli M. (2001) - The control of sea-floor topography on turbidite sedimentation - an example in the Lower Messinian turbidite deposits of the Central Apennines. Abstract volume Research Meeting "Turbidite Sedimentation in Confined Setting" Nizza, 9-11 settembre 2001. Organized by Institute Français du Pétrole and Aberdeen University.

Michard A., Chalouan A., Feinberg H., Goffé B. \& Montigny R. (2002) How does the Alpine belt end between Spain and Morocco? Bulletin de la Société Géologique de France, 173, 3-15.

Moore D. M. \& Reynolds R.C. (1997) - X-Ray Diffraction and the Identification and Analysis of Clay Minerals. 2nd edition New York, Oxford University Press, 378 pp.

Mostardini F. \& Merlini S. (1986) - Appennino centro-meridionale: sezioni geologiche e proposta di modello strutturale. Memorie della Società Geologica Italiana, 35, 177-202.

Mulder T., Syvitski J.P.M., Migeon S., Faugeres J.C. \& Savoye B. (2003) - Marine hyperpycnal flows: initiation, behavior and related deposits. A review. Marine and Petroleum Geology, 20, 861-882.

Mutтi E. (1977) - Distinctive thin-bedded turbidite facies and related depositional environments in the Eocene Hecho Group (SouthCentral Pyrenees, Spain). Sedimentology, 24, 107-131.

Mutti E. (1992) - Turbidite Sandstones. Agip, Istituto di Geologia, Università di Parma, San Donato Milanese, 275 pp.

MutTi E. (2019) - Thin-bedded plumites: an overlooked deep-water deposit. Journal of Mediterranean Earth Sciences, 11, 61-80.

Mutti E. \& NiLsen T.H. (1981) - Significance of intraformational rip-up clasts in deep-sea fan deposits. In: Valloni R., Colella A., Sonnino M., Mutti E., Zuffa G.G. \& Ori G.G. (eds.), Abstract volume International Association of Sedimentologists, 2 ${ }^{\text {nd }}$ European Regional Meeting Bologna 1981, 117-119.

Mutti E. \& Sonnino M. (1981) - Compensation cycles: a diagnostic feature of sandstone lobes. In: In: Valloni R., Colella A., Sonnino M., Mutti E., Zuffa G.G. \& Ori G.G. (eds.), Abstract volume International Association of Sedimentologists, $2^{\text {nd }}$ European Regional Meeting Bologna 1981, 120-123.

Mutti E., Nilsen T.H. \& Ricci Lucchi F. (1978) - Outer fan depositional lobes of the Laga Formation (Upper Miocene and Lower Pliocene), East-Central Italy. In: Stanley, D.L. \& Kelling, G. (eds.), Sedimentation in Submarine Canyons, Fans, and Trenches. Hutchinson \& Ross, Dowen, 201-223.

Mutti E., Davoli G., Mora S. \& Papani L. (1994) - Internal stacking patterns of ancient turbidites systems from collisional basins. In Weimar P., Bouma A.H. \& Perkins, B. (eds.), Submarine Fans and Turbidite Systems. GCS-SEPM Foundation $15^{\text {th }}$ Annual Research Conference, Austin, 257-268.
Mutti E., Davoli G., Tinterri R. \& Zavala C. (1996) - The importance of fluvio-deltaic systems dominated by catastrophic flooding in tectonically active basins. Memorie di Scienze Geologiche, 48, 233-291.

Mutti E., Tinterri R., Di Biase D. Fava L. Mavilla N., Angella S. \& Calabrese L. (2000) - Delta-front facies associations of ancient flood-dominated fluvio-deltaic systems. Revista de la Sociedad Geológica de España, 13, 165-190.

Mutti E., Tinterri R., Remacha E., Mavilla N., Angella S. \& Fava L. (1999) - An introduction to the analysis of ancient turbidite basins from an outcrop perspective. American Association of Petroleum Geologists, Continuing Education Course Note, 39, 61 pp.

Mutti E., Tinterri R., Benevelli G., Di Biase D. \& Cavanna G. (2003) - Deltaic, mixed and turbidite sedimentation of ancient foreland basins. Marine and Petroleum Geology, 20, 733- 755.

Muzzi Magalhaes P. \& Tinterri R. (2010) - Stratigraphy and depositional setting of slurry and contained (reflected) beds in the Marnosoarenacea Formation (Langhian-Serravallian) Northern Apennines, Italy. Sedimentology, 57, 1685-1720.

Parson J.D., Bush J.W. \& Syvitski J.P. (2001) - Hyperpycnal plume formation from riverine outflows with small sediment concentrations. Sedimentology, 48, 465-478.

Patacca E., Scandone P., Bellatalla M., Perilli N. \& Santini U. (1991) - La zona di giunzione tra l'arco appenninico settentrionale e l'arco appenninico meridionale nell'Abruzzo e nel Molise. Studi Geologici Camerti, Volume Speciale 1991/2, 417-441.

Patacca E. \& Scandone P. (2007) - Geology of the southern Apennines. Bollettino della Società Geologica Italiana, 7, 75-119.

Patacci M., Haughton P.D. \& McCaffrey W.D. (2014) - Rheological complexity in sediment gravity flows forced to decelerate against a confining slope, Braux, SE France. Journal of Sedimentary Research, 84, 270-277.

Patacci M., Haughton P.D. \& McCafFrey W.D. (2015) - Flow behavior of ponded turbidity currents. Journal of Sedimentary Research, 85 885-902.

Perri F. (2008) - Clay mineral assemblage of the Middle Triassic-Lower Jurassic mudrocks from Western - Central Mediterranean Alpine Chains. Periodico di Mineralogia 77, 23-40.

Perri F., Muto F. \& Belviso C. (2011) - Links between composition and provenance of Mesozoic siliciclastic sediments from western Calabria (southern Italy). Italian Journal of Geosciences, 130, 318-329.

Perri F., Critelli S., Dominici R., Muto F., Tripodi V. \& Ceramicola S. (2012a) - Provenance and accommodation pathways of late Quaternary sediments in the deep-water northern Ionian Basin, southern Italy. In: CRITElli S., Von EynatTen H., IngERsoll R.V. \& Weltje G. (eds.), Quantitative Models in Sediment Generation. Sedimentary Geology Special Issue, 280, 244-259.

Perri F., Critelli S., Cavalcante F., Mongelli G., Sonnino M., Dominici R. \& De Rosa R. (2012b) - Provenance signatures for the Miocene volcaniclastic succession of the Tufiti di Tusa Formation, southern Apennines, Italy. Geological Magazine, 149, 423-442.

Pescatore T., Salvati G. \& Tramutoli M. (1980) - Regressive depositional cycles in the Gorgoglione Flysch, Irpinids, (Southern Italy). Geologica Romana, 19, 51-61.

Pickering K.T. \& Hilton V.C. (1998) - Turbidite systems of Southeast France. London, United Kingdom, Vallis Press, 232 pp.

Pickering K. \& Hiscott R. (1985) - Contained (reflected) turbidity currents from the Middle Ordovician Clorindome Formation, Quebec, Canada: an alternative to the antidune hypothesis. Sedimentology, 32, 373-394.

Pickering K.T. \& Hiscott R.N. (2016) - Deep Marine Systems. AGU, Wiley, Oxford, 657 pp.

Pickering K.T., Hiscott R.N., Kenyon N.H., Ricci Lucchi F. \& Smith R.D.A. (1995) - Atlas of Deep Water Environments: Architectural Style in Turbidite Systems. London, Chapman \& Hall, 333 pp.

Pollastro R.M. (1985) - Mineralogical and morphological evidence for the formation of illite at the expense of illite/smectite. Clays and Clay Minerals, 33, 265-274.

Postma G., Cartigny M.J.B. \& Kleverlaan K. (2009) - Structureless, coarse-tail graded Bouma Ta formed by internal hydraulic jump of the turbidity current? Sedimentary Geology, 219, 1-6.

Prelat A., Hodgson D.M. \& Flint S.S. (2009) - Evolution, architecture and hierarchy of distributary deep-water deposits: a high-resolution 
outcrop investigation of submarine lobe deposits from the Permian Karoo Basin, South Africa. Sedimentology, 56, 2132- 2154.

Puigdefàbregas C., Gjelberg J. \& Vaksdal M. (2004) - The Grès d'Annot in the Annot syncline: Outer basin-margin onlap and associated soft-sediment deformation. In: JosepH P. \& Lomas L.S. (eds.), DeepWater Sedimentation in the Alpine Foreland Basin of SE France: New Perspectives on the Grès d'Annot and Related Systems. Geological Society London, Special Publicatio, 221, 367-388.

Remacha E., Fernandez L.P. \& Maestro E. (2005) - The transition between sheet-like lobe and basin plain turbidites in the Hecho basin (south-central Pyrenees, Spain). Journal of Sedimentary Research, 75, 789 - 819.

Ricci Lucchi F. (1965) - Alcune strutture di risedimentazione nella Formazione Marnoso-arenacea romagnola. Giornale di Geologia, 33, 265-292.

Ricci Lucchi F. \& VALMORI E. (1980) - Basin-wide turbidites in a Miocene, over supplied deep-sea plain: a geometrical analysis. Sedimentology, 27, 241-270.

SANTo A. \& Sgrosso I. (1987) - Alcune precisazioni sulle trasgressioni "mioceniche" nell'Appennino meridionale. Memorie della Società Geologica Italiana, 38, 225-240.

Scarciglia F., Le Pera E. \& CRItelli S. (2007) - The onset of sedimentary cycle in a mid-latitude upland environment: weathering, pedogenesis and geomorphic processes on plutonic rocks (Sila Massif, Calabria). In: Arribas J., Critelli S. \& Johnsson M. (eds.), Sedimentary Provenance: Petrographic and Geochemical Perspectives. Geological Society of America, Special Paper 420, 149-166.

Scarciglia F., Critelli S., Borrelli L., Coniglio S., Muto F. \& Perri F. (2016) - Weathering profiles in granitoid rocks of the Sila Massif uplands, Calabria, southern Italy: new insights into their formation processes and rates. Sedimentary Geology, 336, 46-67.

Scrocca D. (1996) - La zona d'interferenza tra le strutture dell'Appennino centrale e meridionale: assetto tettonico ed evoluzione del sistema di sovrascorrimenti. Ph.D. Thesis, SAPIENZA Università di Roma, $268 \mathrm{pp}$.

Scrocca D. (2010) - Southern Apennines: structural setting and tectonic evolution. In: Beltrando M., Peccerillo A., Mattei M., Conticell S. \& Doglioni C. (eds.), The Geology of Italy: Tectonics and Life Along Plate Margins. Journal of the Virtual Explorer, 36, paper 14.

Scrocca D., Tozzi M. \& Parotto M. (1995) - Assetto strutturale del settore compreso tra il Matese, le Mainarde e l'unità di Frosolone. Implicazioni per l'evoluzione neogenica del sistema di sovrascorrimenti nell'Appennino centro-meridionale. Studi Geologici Camerti, Volume Speciale 1995/2, 407-418.

SincLAIR H.D. (2000) - Delta-fed turbidites infilling topographically complex basins: a new depositional model for the Annot Sandstones, SE France. Journal of Sedimentary Research, 70, 504-519.

Smeraglia L., Aldega L., Billi A., Carminati E., Di Fiore F., Gerdes A., Albert R., Rossetti F. \& Vignaroli G. (2019) - Development of an intrawedge tectonic mélange by out-of-sequence thrusting, buttressing, and intraformational rheological contrast, Mt. Massico ridge, Apennines, Italy. Tectonics, 38, 1223-1249.

SMith R. \& Joseph P. (2004) - Onlap stratal architectures in the Grès d'Annot: Geometric models and controlling factors. In: JosEPH P. \& Lomas S.A. (eds.), Deep-water Sedimentation in the Alpine Basin of SE France: New Perspectives on the Grès d'Annot and Related Systems. Geological Society London, Special Publication, 221 389-399.

Speranza F., Mattei M., Naso G., Di Bucci D. \& Corrado S. (1998) Neogene-Quaternary evolution of the central Apennine orogenic system (Italy): a structural and palaeomagnetic approach in the Molise region. Tectonophysics, 299, 143-157.

Southern S.J., Patacci M., Felletti F. \& McCaffrey W.D. (2015) Influence of flow containment and substrate entrainment upon sandy hybrid event beds containing a co-genetic mud-clast-rich division. Sedimentary Geology, 321, 105-122.

Spychala Y.T., Hodgson D.M., Prelat A., Kane I.A., Flint S.S. \& Mountney N.P. (2017) - Frontal and lateral submarine lobe fringes: comparing sedimentary facies, architecture and flow processes. Journal of Sedimentary Research, 87, 75-96.

Sylvester Z. \& Lowe D.R. (2004) - Textural trends in turbidites and slurry beds from the Oligocene flysch of the East Carpathians, Romania. Sedimentology, 51, 945 - 972.

Stalder N.F., Fellin M.G., Caracciolo L., Guillong M., Winkler W. Milli S., Moscatelli M. \& Critelli S. (2018) - Dispersal pathways in the early Messinian Adriatic foreland and provenance of the Laga Formation (Central Apennines, Italy). Sedimentary Geology, 375, 289-308.

Sumner E.J., Talling P.J. \& Amy L.A. (2009) - Deposits of flows transitional between turbidity current and debris flow. Geology, 37, $991-994$.

Talling P.J., Amy L.A., Wynn R.B., Peakall J. \& Robinson M. (2004) - Beds comprising debris sandwiched within co-genetic turbidite: origin and widespread occurrence in distal depositional environments. Sedimentology, 51, 163-194.

Talling P.J., Malgesini G., Sumner E.J., Amy L.A., Felletti F., Blackbourn G., Nutt C., Wilcox C., Harding I.C., Akbari S. (2012) Planform geometry, stacking pattern, and extrabasinal origin of low strength and intermediate strength cohesive debris flow deposits in the Marnoso-arenacea Formation, Italy. Geosphere, 8, 1207-1230.

TAYLOR S.R. \& McLennAN S.M. (1985) - The continental crust: Its composition and evolution. Oxford, Blackwells, $312 \mathrm{pp}$.

Tinterri R. \& Muzzi Magalhaes P. (2011) - Synsedimentary structural control on foredeep turbidites: An example from Miocene Marnosoarenacea Formation, Northern Apennines, Italy. Marine and Petroleum Geology, 28, 629-657.

Tinterri R. \& TAgliafferri R. (2015) - The syntectonic evolution of foredeep turbidites related to basin segmentation: facies response to the increase in tectonic confinemen (Marnoso-arenacea Formation, Miocene, Northern Apennines, Italy). Marine and Petroleum Geology, 67, 81-110.

VAN Vliet A. (1978) - Early Tertiary deepwater fans of Guipuzcoa, Northern Spain. In: Stanley D.J. \& Kelling G. (eds.), Sedimentation in Submarine Canyons, Fans and Trenches. Dowden, Hutchinson and Ross, Strausbourg, 190-209.

VITALE S. \& CIARCIA S. (2013) - Tectono-stratigraphic and kinematic evolution of the southern Apennines/Calabria-Peloritani Terrane system (Italy). Tectonophysics, 583, 164-182.

Weltue G.J. (2002) - Quantitative analysis of detrital modes: statistically rigoorous confidence regions in ternary diagrams and their use in sedimentary petrology. Earth-Science Reviews, 57, 211-253.

Zecchin M., Civile D., Caffau M., Muto F., Di Stefano A., Maniscalco R. \& CRITELli S. (2013a) - The Messinian succession of the Crotone Basin (southern Italy) I: Stratigraphic architecture reconstructed by seismic and well data. Marine and Petroleum Geology, 48, 455473.

Zecchin M., Caffau M., Di Stefano A., Maniscalco R., Lenaz D., Civile D., Muto F., \& Critelli S. (2013b) - The Messinian succession of the Crotone Basin (southern Italy) II: Facies architecture and stratal surfaces across the Miocene-Pliocene boundary. Marine and Petroleum Geology, 48, 474-492.

Zecchin M., Civile D., Caffau M., Critelli S., Muto F., Mangano G. \& Ceramicola S. (2020) - Sedimentary evolution of the NeogeneQuaternary Crotone Basin (southern Italy) and relationships with large-scale tectonics: A sequence stratigraphic approach. Marine and Petroleum Geology, 117, 104381.

ZuFFA G.G. (1980) - Hybrid arenites, their composition and classification. Journal of Sedimentary Petrology, 50, 21-29.

ZuFFa G.G. (1985) - Optical analyses of arenites: influence of methodology on compositional results. In: Zuffa G.G. (ed.), Provenance of Arenites. NATO-ASI, Dordrecht, Reidel, 165-189.

ZUFFA G.G. (1987) - Unravelling hinterland and offshore palaeogeography from deepwater arenites. In: LEGGETT J.K. \& ZUFFA, G.G. (eds.), Marine Clastic Sedimentology. Models and Case Studies. London, Graham and Trotman, 39-61. 